\title{
Phase Equilibria and Crystallography of Ceramic Oxides
}

W. Wong-Ng, R. S. Roth, T. A. Vanderah, and H. F. McMurdie

National Institute of Standards and Technology,

Gaithersburg, MD 20899-8520

winnie.wong-ng@nist.gov

robert.roth@nist.gov

terrell.vanderah@nist.gov
Research in phase equilibria and crystallography has been a tradition in the Ceramics Division at National Bureau of Standards/National Institute of Standatrds and Technology (NBS/NIST) since the early thirties. In the early years, effort was concentrated in areas of Portland cement, ceramic glazes and glasses, instrument bearings, and battery materials. In the past 40 years, a large portion of the work was related to electronic materials, including ferroelectrics, piezoelectrics, ionic conductors, dielectrics, microwave dielectrics, and high-temperature superconductors. As a result of the phase equilibria studies, many new compounds have been discovered. Some of these discoveries have had a significant impact on US industry. Structure determinations of these new phases have often been carried out as a joint effort among NBS/NIST colleagues and also with outside collaborators using both single crystal and neutron and x-ray powder diffraction techniques. All phase equilibria diagrams were included in Phase Diagrams for Ceramists, which are collaborative publications between The American Ceramic Society (ACerS) and NBS/NIST. All x-ray powder diffraction patterns have been included in the Powder Diffraction File (PDF). This article gives a brief account of the history of the development of the phase equilibria and crystallographic research on ceramic oxides in the $\mathrm{Ce}$ ramics Division. Represented systems, particularly electronic materials, are highlighted.

Key words: ceramic oxides; crystal chemistry; crystallography; electronic materials; historical development; phase equilibria.

Accepted: August 22, 2001

Available online: http://www.nist.gov/jres

\section{Introduction}

Phase diagrams are critical research tools for many scientific disciplines, including material science, ceramics, geology, physics, metallurgy, chemical engineering, and chemistry. Phase diagrams can be regarded as "road maps" for materials processing. These diagrams contain important information for the development of new materials, control of structure and composition of critical phases, and improvement of properties of technologically important materials. Applications of phase diagrams range from the preparation of high quality single crystals, single-phase bulk materials, deliberate precipitation of second phases, to the formation of melts. Studies of phase equilibria and crystallography of materials are strongly correlated. Crystallographic information is critical for furthering the understanding of phase equilibria, crystal chemistry, physical properties of materials, and performing various theoretical calculations.

Phase equlibria and crystallographic research at NBS/ NIST has been an important program since the 1930s. Development of new technologies based on ceramic oxides continued to require new materials and new equipment. As a result, a large number of new phases in a diverse area of material science have been discovered and characterized at NBS/NIST. Methods of structural characterization include single crystal $\mathrm{x}$-ray, powder neutron and x-ray methods, and electron diffraction. 
Since powder x-ray diffraction patterns are critical for phase identification, patterns of the new phases were also prepared and were included in the Powder Diffraction File (PDF [1]). Throughout these years, NBS/NIST has collaborated with various important ceramic industries, and the systems investigated reflected the changing emphasis of material systems, including cement, glasses, battery materials, dielectrics, ferroelectrics, ionic conductors, superconductors, microwave materials, magnetic materials, and materials for optical applications.

In the following, highlights of the phase equilibria and crystallographic research of oxide materials in the Ceramics Division will be followed by more detailed discussions pertaining to the dielectric and superconductor systems.

\section{Historical Development}

\subsection{The Early Years (1930s to mid 1960s)}

In the twenties, the Clay and Silicate Product Division at NBS (which later became the Ceramics Division) had seven Sections that were all product-oriented. Examples of these sections were "Heavy Clay Products", "White Ware", "Enamels", and "Lime and Gypsum". The functions of these Sections were primarily to develop specifications and to perform testing for government agencies. As an example, bricks were tested for water absorption and for resistance to freezing and thawing as a preliminary to writing specifications. The idea of either "crystallography" or "phase equilibria" of materials was hardly considered. Between the 1930s and mid 1960s, H. F. McMurdie and his colleagues pioneered the studies of the phase relationships and crystallographic aspects of ceramic materials. A portion of the study was also conducted in collaboration with both internal and external laboratories.

\subsubsection{Portland Cement}

One of the early phase diagram studies was reported in 1936 on the formation of $\mathrm{MgO}$ in the compositions of Portland cement [2]. Portland cement clinker consists essentially of lime, alumina, silica, ferric oxide, and magnesia. The last two phases may be generally considered as occurring incidentally, as impurities in the basic raw material. Since $\mathrm{MgO}$ could be harmful in cement, it would be important to determine its behavior in the cement to establish the composition ranges within which $\mathrm{MgO}$ appears as a primary phase (the first crystalline phase to appear on cooling a composition from the liquid state). This work was completed primarily by quenching and petrographic microscopy. Figure 1 shows the phase diagram of the $\mathrm{CaO}-\mathrm{MgO}-2 \mathrm{CaO} \cdot \mathrm{SiO}_{2}{ }^{-}$ $5 \mathrm{CaO} \cdot 3 \mathrm{Al}_{2} \mathrm{O}_{3}$ system. The surface intersecting the sides of the tetrahedron at A-B-C-D-E-F-G indicates the lower level ( $4 \%$ to $5 \%$ ) of the primary phase field (the locus of all compositions in a phase diagram having a common primary phase) of $\mathrm{MgO}$. $\mathrm{MgO}$ has an exceptionally large primary phase field.

The structural characterization of the products of hydration of Portland cement was carried out by petrographic and powder $\mathrm{x}$-ray techniques [3] with the phases synthesized by hydrothermal methods. The main finding was that the group of compounds $\mathrm{Ca}_{3} \mathrm{Al}_{2} \mathrm{Si}_{3} \mathrm{O}_{12}$ (andradite), $\mathrm{Ca}_{3} \mathrm{Fe}_{2} \mathrm{Si}_{3} \mathrm{O}_{12}$ (grossularite), $\mathrm{Ca}_{3} \mathrm{Al}_{3} \mathrm{H}_{12} \mathrm{O}_{12}$ and $\mathrm{Ca}_{3} \mathrm{Fe}_{2} \mathrm{H}_{12} \mathrm{O}_{12}$ form a complete series of solid solutions, with a garnet structure. The phases with hydrogen were called hydrogarnets. All these compounds were found to be cubic with space group $I a 3 d$.

\subsubsection{Ceramic Glazes and Glasses}

In the thirties, information on phases in the $\mathrm{PbO}-\mathrm{SiO}_{2}$ system was needed in connection with the studies of ceramic glazes and glasses. Four phases were found in this system and their $\mathrm{x}$-ray diffraction patterns were determined by Geller et al. [4], and McMurdie and Bunting [5]. These studies used both x-ray diffraction and petrographic microscopy methods. In addition, $\mathrm{x}-$ ray patterns of phases of the $\mathrm{K}_{2} \mathrm{O}-\mathrm{PbO}-\mathrm{SiO}_{2}, \mathrm{PbO}-\mathrm{SiO}_{2}$, and the $\mathrm{Na}_{2}-\mathrm{PbO}-\mathrm{SiO}_{2}$ systems were prepared in cooperation with the Whiteware Section.

In the late forties, phase equilibrium information for the system $\mathrm{BaO}-\mathrm{B}_{2} \mathrm{O}_{3}-\mathrm{SiO}_{3}$ and the subsystem $\mathrm{BaO}$ $\mathrm{B}_{2} \mathrm{O}_{3}[6]$ were of importance to the glass industry as a starting point for the investigations of barium crown glasses (see Fig. 2). These glasses are characterized by high refractive index and low dispersion. The experiments included quenchings and the use of differential thermal analysis (DTA). Phases were identified by microscopy and x-ray diffraction. X-ray patterns of four phases including the low form of $\mathrm{BaB}_{2} \mathrm{O}_{4}$ were reported in the $\mathrm{BaO}-\mathrm{B}_{2} \mathrm{O}_{3}$ system. A two-liquid region (liquid immiscibility) was found. In the ternary system $\mathrm{BaO}-$ $\mathrm{B}_{2} \mathrm{O}_{3}-\mathrm{SiO}_{2}$ system [7], one ternary phase, $\mathrm{Ba}_{3} \mathrm{~B}_{6} \mathrm{Si}_{2} \mathrm{O}_{16}$, was discovered and a large two-liquid region was also located (Fig. 4). The system $\mathrm{BaO}-\mathrm{SiO}_{2}$ was later modified by Roth and Levin [8] to show the existence of several new compounds between $\mathrm{BaO} \cdot 2 \mathrm{SiO}_{2}$ and $2 \mathrm{BaO} \cdot 3 \mathrm{SiO}_{2}$ in the region labeled as "solid solutions" in Fig. 3.

In the fifties, the condition of immiscibility in borate and silicate systems and its frequent occurrence had been noted by J. W. Greig and F. C. Kracek at the Geophysical Laboratory. Since it was important as a 


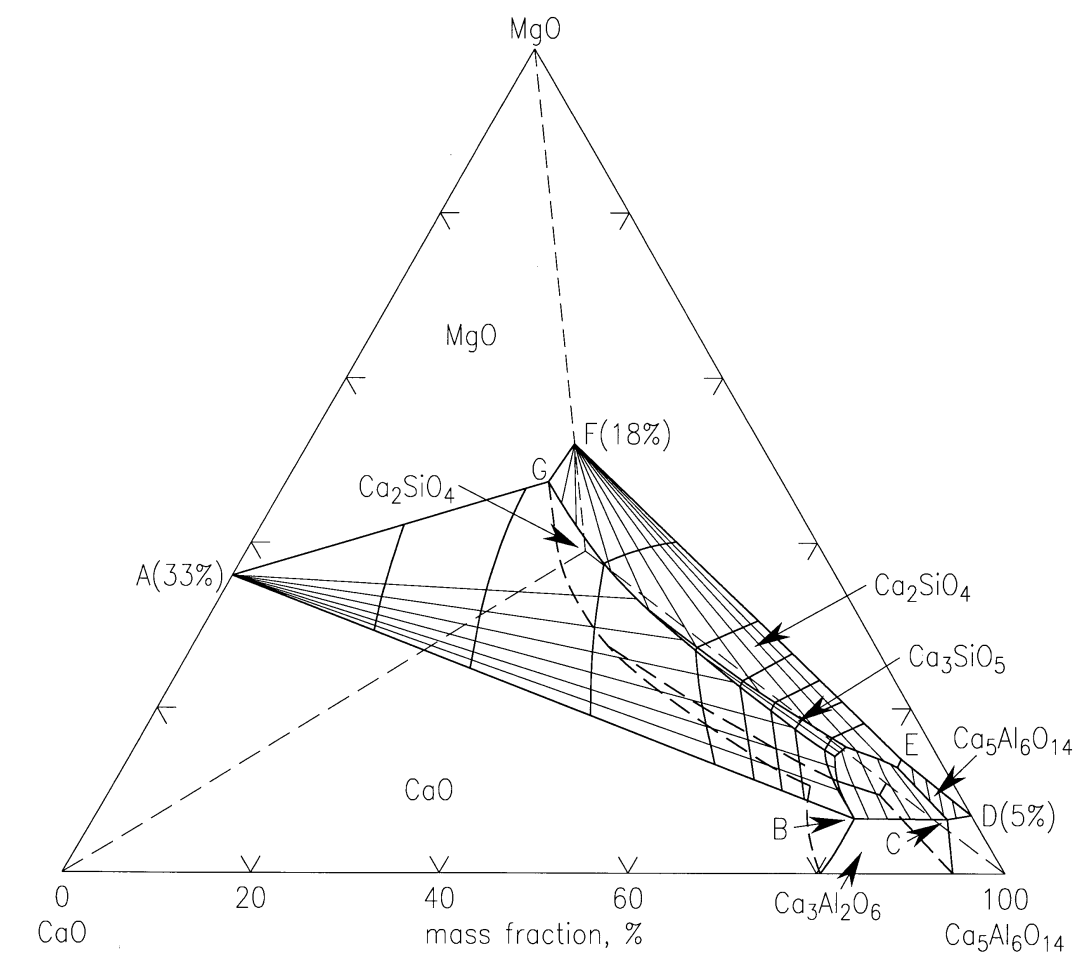

Fig. 1. (a) Phase diagram of the system $\mathrm{CaO}-\mathrm{MgO}-2 \mathrm{CaO} \cdot \mathrm{SiO}_{2}-5 \mathrm{CaO} \cdot 3 \mathrm{Al}_{2} \mathrm{O}_{3}[2]$; the surface intersecting the sides of the tetrahedron at A-B-C-D-E-F-G indicates the lower level of the primary-phase volume of $\mathrm{MgO} ; \mathrm{C}_{3} \mathrm{~S}=3 \mathrm{CaO} \cdot \mathrm{SiO}_{2} ; \mathrm{C}_{2} \mathrm{~S}=2 \mathrm{CaO} \cdot \mathrm{SiO}_{2} ; \mathrm{C}_{3} \mathrm{~A}=3 \mathrm{CaO} \cdot \mathrm{Al}_{2} \mathrm{O}_{3}$; $\mathrm{C}_{5} \mathrm{~A}_{3}=5 \mathrm{CaO} \cdot 3 \mathrm{Al}_{2} \mathrm{O}_{3}$. 1(b).

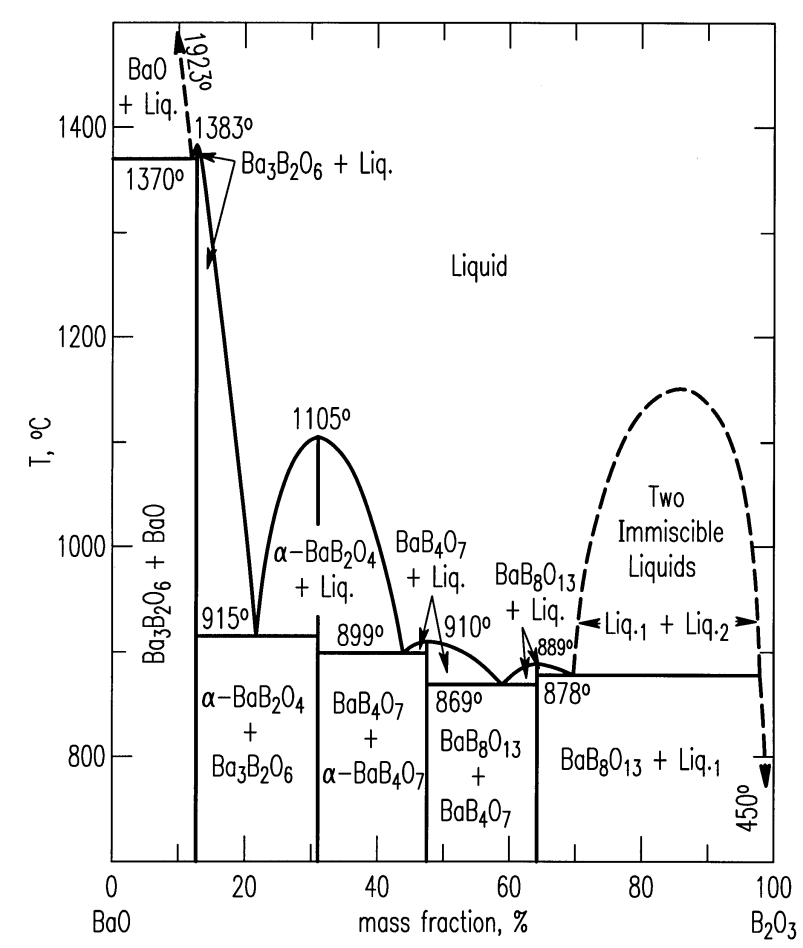

commercial and scientific problem to understand the basic causes of liquid immiscibility, Levin and Block [9, 10] attempted to interpret this phenomenon quantitatively by applying crystal-chemical principles to nineteen binary and eight ternary glass systems. Using ionic radii and one of the two coordination types (for glassformer cations and for modifier cations), they found that the additive density method gives agreement with experimental results in both the borate and silicate systems to within a mole fraction of $5 \%$. The oxygen-volume method agrees to within $2 \%$ (mole fraction).

In the early sixties, in order to assist the U.S. industry to develop new compositions and search for better property for optical glass, the system $\mathrm{La}_{2} \mathrm{O}_{3}-\mathrm{B}_{2} \mathrm{O}_{3}$ was studied by Levin et al. [11] by the quenching method. Phases were identified by petrographic microscopy and $\mathrm{x}$-ray diffraction. Three binary compounds were found and no solid solution was encountered in this system. $\mathrm{LaBO}_{3}$ was of aragonite type with a polymorphic change at $1488^{\circ} \mathrm{C}$ to a form similar to calcite. A twoliquid region was found but no solid solution was detected.

Fig. 2. Phase diagram of the system $\mathrm{BaO}-\mathrm{B} 2 \mathrm{O} 3$ [6]. Liquid immiscibility was observed. 


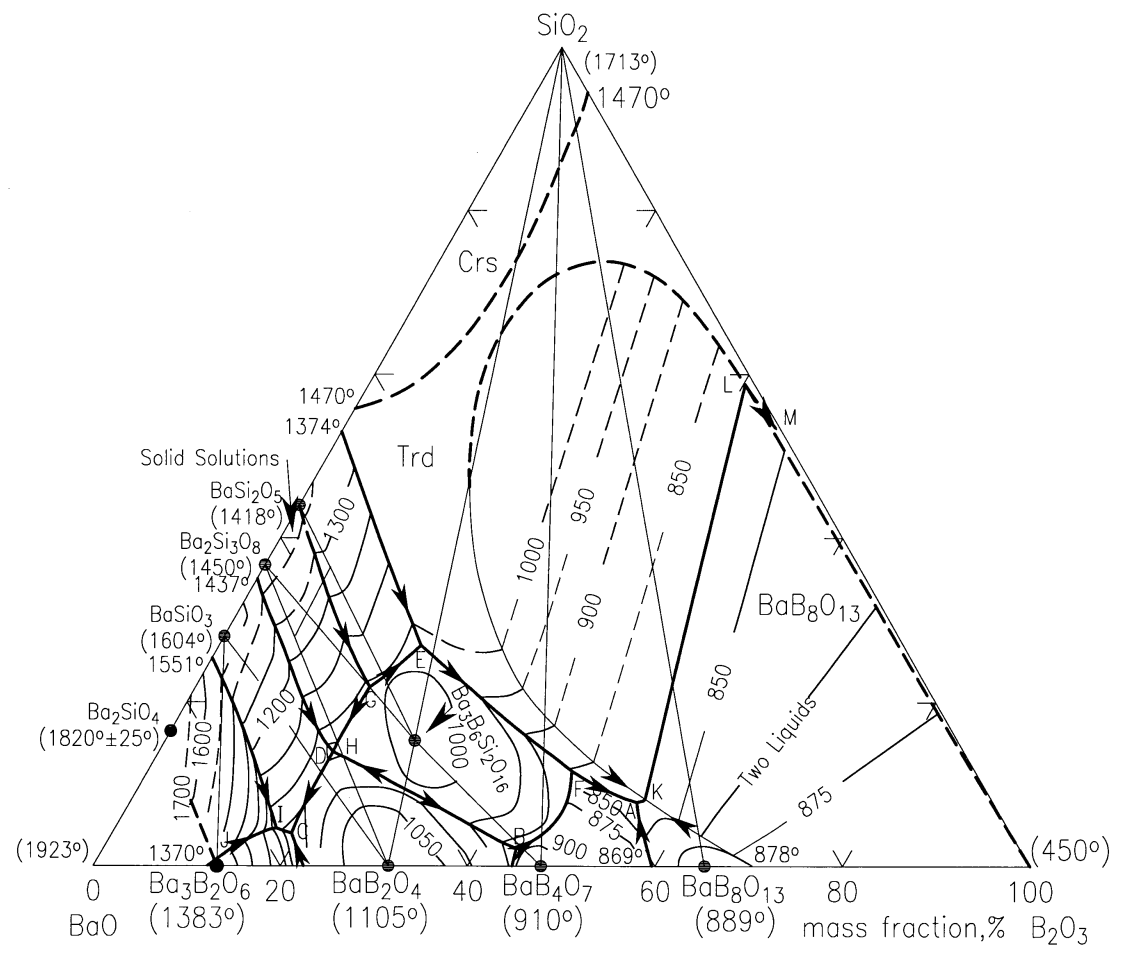

Fig. 3. Phase diagram of the system $\mathrm{BaO}-\mathrm{B}_{2} \mathrm{O}_{3}-\mathrm{SiO}_{2}$ [7].

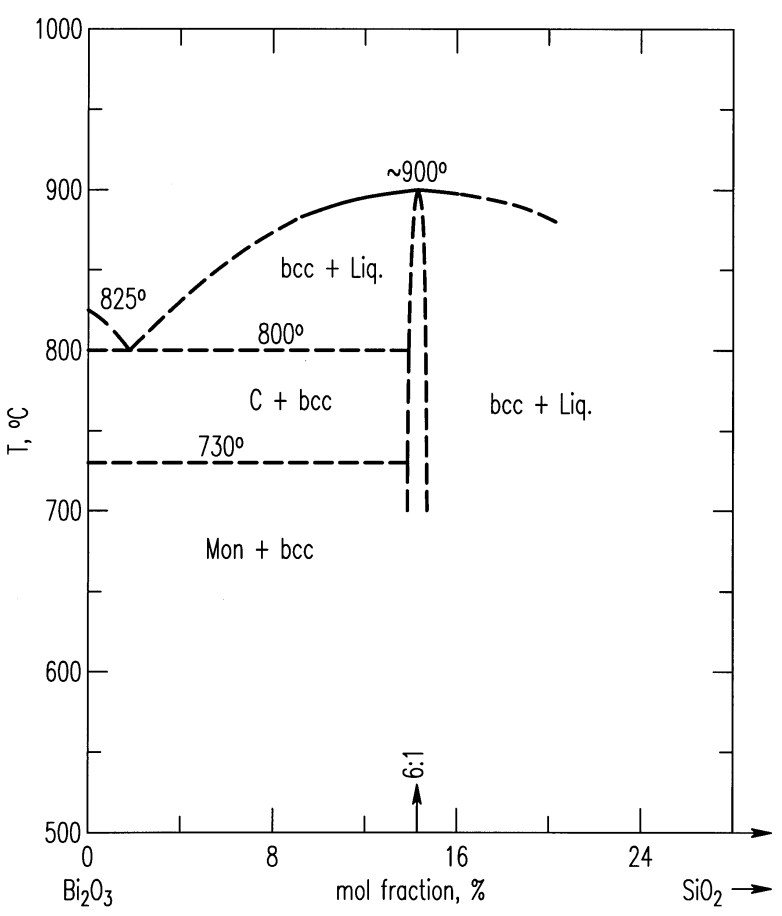

Fig. 4. Phase diagram of the system $\mathrm{Bi}_{2} \mathrm{O}_{3}-\mathrm{SiO}_{2}$ [34].

\subsubsection{Properties of Materials for Jewel Instrument Bearings}

Around the mid-forties, in the course of an investigation on jewel bearings for instruments, conducted under authorization of the Bureau of Aeronautics, United States Navy, NBS made a number of tests and examinations of various materials, included corundum (natural and synthetic), synthetic spinel and glass [12]. The natural corundum samples originally were from Montana. Synthetic corundum was prepared by the Verneuil Method. The properties measured were homogeneity, structural defects, hardness, and strength. It was found that although the corundum has the greatest hardness and strength, its hardness is much greater than that of the usual steel instrument pivots which would cause the pivots to deform or rust. Glass has about the same hardness as the pivots but glass bearings may break under vibration and impact. Spinel is intermediate between corundum and glass in strength and hardness.

\subsubsection{Battery Materials}

In the mid-forties, because of World War II, dry cells were put to many new uses involving conditions of extreme heat and cold, and storage over long periods of time. At the request of the Electrochemical Section a study was conducted to characterize a large number of 
dry battery materials (mainly $\mathrm{MnO}_{2}$ ), related synthetic materials and natural minerals [13]. This task showed an early example of combining a number of crystallographic methods, namely, x-ray diffraction (both at room temperature and at elevated temperatures [14] for phase identification and phase transformation studies), DTA for the study of thermal events, and the electron microscope for particle size and surface characterization. $\mathrm{MnO}_{2}$ was found to lose oxygen at about $600{ }^{\circ} \mathrm{C}$ and $950{ }^{\circ} \mathrm{C}$ to bixbyite $\left(\mathrm{Mn}_{2} \mathrm{O}_{3}\right)$ and $\mathrm{Mn}_{3} \mathrm{O}_{4}$ (hausemannite). A reversible polymorphic change from the tetragonal hausemannite to a spinal form was also determined.

Related to the work on battery materials, a characterization study was conducted on the phases formed during the discharge of cells. The main Mn-containing phase found after discharge was hetaerolite $\left(\mathrm{ZnMn}_{2} \mathrm{O}_{4}\right)$ in which the valence of $\mathrm{Mn}$ is 3. A smaller amount of $\mathrm{ZnCl}_{2} \cdot 4 \mathrm{Zn}(\mathrm{OH})_{2}$ was also found $[15,16]$.

\subsubsection{Uranium Dioxide with Metal Oxides}

In the mid-fifties, investigation of the high-temperature reactions of uranium with a large variety of materials comprised an important segment of the research activities of the U.S. Atomic Energy Commission and many of its contractors. In the Porcelain and Pottery Section of the NBS, a project for the determination of the phase-equilibrium relations of binary systems containing $\mathrm{UO}_{2}$ and various metal oxides was carried out by Roth et al. [17]. This study also included a critical review of the phase relations at high temperature of $\mathrm{UO}_{2}$ with 15 other oxides $(\mathrm{BeO}, \mathrm{MgO}, \mathrm{CaO}, \mathrm{SrO}, \mathrm{BaO}, \mathrm{CuO}$, $\mathrm{Al}_{2} \mathrm{O}_{3}, \mathrm{Y}_{2} \mathrm{O}_{3}, \mathrm{Nd}_{2} \mathrm{O}_{3}, \mathrm{SiO}_{2}, \mathrm{ZrO}_{2}, \mathrm{SnO}_{2}, \mathrm{CeO}_{2}, \mathrm{ThO}_{2}$, $\mathrm{V}_{2} \mathrm{O}_{5}$ ). As part of this work, the technology was developed for $\mathrm{ZrO}_{2}$ clad $\mathrm{VO}_{2}$ fuel pellets, used to this day for the fuel rods in all modern nuclear reactors.

\subsection{Period of $1960 \mathrm{~s}$ to late $1980 \mathrm{~s}$}

After the retirement of H. F. McMurdie in 1966, the Crystallographic Section of the Ceramics Division was headed by S. Block, and the Phase Equilibria Section was headed by R. S. Roth. The program of the crystallographic section was divided into several long-term disciplines [18]: 1) structure determinations (e.g., a great number of borates and inorganic complexes [19,20]), 2) high pressure (see High Pressure Crystallography), 3) powder diffraction (primarily the determination of standard patterns with the JCPDS-ICDD (see JCPDS-ICDD collaborative program), and 4) the Crystal Data Project (supported by the Standard Reference Data Program) [21].
During this period, R. S. Roth and his co-workers made significant contributions to the phase equilibria and crystal chemistry research of a great variety of important classes of ceramics (over 200 publications today). Of special note was the paper on the classification of $\mathrm{ABO}_{3}$ compounds with emphasis on the perovskite structure type phases [22]. In order to understand the crystal chemistry of these phases in detail, many single crystals were grown. As crystal growth of the high-temperature oxides was not a straight-forward task due to the high melting temperature and the incongruent melting nature of most oxides in the systems of interest, a low-temperature flux was often used as an aid. Crystallographic investigations were largely carried out involving international collaborations (A. D. Wadsley, S. Anderson, N. C. Stevenson, B. M. Gatehause, I. E. Grey, etc.). Selective studies of the phase equilibria, crystal chemistry and crystallography of important ceramics during this period are summarized below.

\subsubsection{Ferroelectric Materials}

The viable applications of $\mathrm{BaTiO}_{3}$ in various fields of industry, including the ferroelectric with the simplest structure, has made this compound a subject of much investigation for many years. Roth et al. conducted a detailed study of the phase diagram of the $\mathrm{BaTiO}_{3}-\mathrm{TiO}_{2}$ system, which will be discussed in the section of the dielectric materials [23]. Other Ba-containing materials being studied that are of potential ferroelectric applications systems included $\mathrm{Ba}_{6} \mathrm{Nb}_{28 / 3} \mathrm{Ni}_{2 / 3} \mathrm{O}_{30}$ [24] and $\left(\mathrm{Ba}_{6-2 x} \mathrm{R}_{2 x}\right)\left(\mathrm{Nb}_{9-x} \mathrm{Fe}_{1+x}\right) \mathrm{O}_{30}$ [25].

Because of the ferroelectric properties of the compound $\mathrm{Cd}_{2} \mathrm{Nb}_{2} \mathrm{O}_{7}$ below room temperature, the phase equilibria of the $\mathrm{CdO}-\mathrm{Nb}_{2} \mathrm{O}_{5}$ system was of interest [26]. Based on the pyrochore type structure of $\mathrm{Cd}_{2} \mathrm{Nb}_{2} \mathrm{O}_{7}$, Roth has also surveyed the reactions occurring in binary oxide mixtures of the type $\mathrm{A}_{2} \mathrm{O}_{3}: 2 \mathrm{BO}_{2}$ as part of the program on ferroelectric ceramics $(\mathrm{A}=\mathrm{La}, \mathrm{Nd}, \mathrm{Sm}$, $\mathrm{Gd}, \mathrm{Bi}, \mathrm{Y}, \mathrm{Dy}, \mathrm{Yb}, \mathrm{In}, \mathrm{Sb} ; \mathrm{B}=\mathrm{Ce}, \mathrm{U}, \mathrm{Ti}, \mathrm{Sn}$, and $\mathrm{Zr}$ ) [27]. On the basis of the existence of the two compounds, $\mathrm{La}_{2} \mathrm{O}_{3} \cdot 2 \mathrm{ZrO}_{2}$ and $\mathrm{Nd}_{2} \mathrm{O}_{3} \cdot 2 \mathrm{ZrO}_{2}$, the phase diagrams for the systems $\mathrm{La}_{2} \mathrm{O}_{3}-\mathrm{ZrO}_{2}$ and $\mathrm{Nd}_{2} \mathrm{O}_{3}-\mathrm{ZrO}_{2}$ were also determined.

Another system of interest was $\mathrm{PbO}-\mathrm{Nb}_{2} \mathrm{O}_{5}$ [28] because of the orthorhombic ferroelectric modification phase of $\mathrm{PbNb}_{2} \mathrm{O}_{6}$ [29]; there were contradictory literature reports about the phase transformation of this phase. High-temperature $\mathrm{x}$-ray patterns indicated that pure $\mathrm{PbO} \cdot \mathrm{Nb}_{2} \mathrm{O}_{5}$ has a tetragonal symmetry as a stable modification from the temperature of the high-low phase transformation to the melting point. If the hightemperature modification is cooled quickly from below 
the transformation point, it will maintain the tetragonal structure in a metastable condition. When it reaches the Curie point of $590{ }^{\circ} \mathrm{C}$ [30], it transforms metastably and reversibly to the orthorhombic ferroelectric modification.

\subsubsection{Piezoelectric Ceramics}

Piezoelectric properties of $\mathrm{BaTiO}_{3}$ ceramic have simulated a search for other ferroelectrics suitable for fabricating piezoelectric ceramics. Of particular interest was to discover materials having electrical mechanical properties that are stable through a wide range of temperature. Roth's work in the area of piezoelectric ceramics was extensive. In the mid-fifties, Roth et al. studied the systems $\mathrm{PbZrO}_{3}-\mathrm{PbTiO}_{3}, \mathrm{PbTiO}_{3}-\mathrm{PbO}: \mathrm{SnO}_{2}, \mathrm{PbTiO}_{3}$ $\mathrm{PbZrO}_{3}-\mathrm{PbO}: \mathrm{SnO}_{2}$, and $\mathrm{PbTiO}_{3}-\mathrm{PbHfO}_{3}$ [31,32], and discovered the possible desirable properties of compositions near a morphotropic transformation between ferroelectric solid-solution phases. Piezoelectric properties of the lead zirconate-lead titanate solid solution that was discovered in the $\mathrm{PbZrO}_{3}-\mathrm{PbTiO}_{3}$ system [32], now known as PZT, have made PZT one of the most important advanced electronic ceramic materials known to this day. This material also revolutionized various industries with its diverse applications.

Three series of partial phase diagrams of the $\mathrm{Bi}_{2} \mathrm{O}_{3}$ $\mathrm{MO}_{x}$ systems $(x=1, \mathrm{M}=\mathrm{Ni}, \mathrm{Zn}, \mathrm{Cd}, \mathrm{Mg}, \mathrm{Ca}, \mathrm{Sr}, \mathrm{Ba}$, $\mathrm{Pb} ; x=1.5, \mathrm{M}=\mathrm{B}, \mathrm{Al}, \mathrm{Ga}, \mathrm{Fe}, \mathrm{Mn}, \mathrm{Sb}, \mathrm{Lu}, \mathrm{Sm}, \mathrm{La}$; $x=2, \mathrm{M}=\mathrm{Si}, \mathrm{Ge}, \mathrm{Ti}, \mathrm{Sn}, \mathrm{Zr}, \mathrm{Ce}, \mathrm{Te}$ ) were determined in order to determine the influence of various foreign cations on the polymorphism of $\mathrm{Bi}_{2} \mathrm{O}_{3}[33,34]$. As these phases were reported to melt congruently they became ideal candidates for crystal growth. Fig. 4 gives an example of the diagram of the $\mathrm{Bi}_{2} \mathrm{O}_{3}-\mathrm{SiO}_{2}$ system. This study resulted in the development of a sought-after piezoelectric material, $\mathrm{SiBi}_{12} \mathrm{O}_{20}$, a phase with the largest known rotary inversion of any oxide compound at the time, and is of considerable commercial interest. A structural analysis proved that the phase was noncentrosymmetric. Small tetravalent ions were found to stabilize the cubic body-centered phase. Body centered cubic bismuth oxide is now believed to be a mixed valence compound with a formula $\mathrm{Bi}^{+5}{ }_{0.5} \mathrm{Bi}^{+3}{ }_{12.5} \mathrm{O}_{20}$. Roth et al. also found that $\mathrm{BaO}, \mathrm{SrO}$, and $\mathrm{CaO}$ entered into the solid solution causing an increase in the melting point of $\mathrm{Bi}_{2} \mathrm{O}_{3}$. This solid solution with apparent rhombohedral symmetry was found to have interesting oxygen ion conductivity.

\subsubsection{Solid State Ionic Conductors}

In the eighties, there was a significant interest in materials which undergo topotactic insertion of lithium because of their potential use as electrode materials in secondary batteries [35,36]. Lithium is ionic in these compounds, and the charge is compensated by a reduction of the host cations. The host structures may be of the layer or framework type. In general, in the framework type structure, $\mathrm{Li}^{+}$ions occupy formerly vacant cation sites, and in the layer type structure, they are accommodated in the van der Waals gap between layers.

In collaboration with the Bell Telephone Laboratories, two structure types and their derivatives were found to be particularly suitable for lithium insertion reactions, namely, rutile structure $\left(\mathrm{TiO}_{2}\right)$ related oxides, and $\mathrm{ReO}_{3}$ type structure $[35,36]$. The crystal chemistry and structure of a large number of lithium-inserted metal oxides have been studied [32-52]: $\mathrm{Li}_{x} \mathrm{ReO}_{3} \quad(x=1,2)$, $\mathrm{Li}_{0.35} \mathrm{ReO}_{3}, \quad \mathrm{Li}_{2} \mathrm{FeV}_{3} \mathrm{O}_{8}, \mathrm{Li}_{2} \mathrm{SnO}_{3}, \mathrm{Li}_{2} \mathrm{ZrO}_{3}, \mathrm{Li}_{3} \mathrm{TaO}_{4}$, $\mathrm{LiTa}_{3} \mathrm{O}_{8}, \quad \mathrm{Li}_{2} \mathrm{FeV}_{3} \mathrm{O}_{8}, \quad \mathrm{Li}_{0.5} \mathrm{TiO}_{2}, \quad \mathrm{LiTi}_{2} \mathrm{O}_{4}$, $\mathrm{Li}_{325} \mathrm{La}_{5625} \mathrm{MoO}_{4}, \delta \mathrm{LiV}_{2} \mathrm{O}_{5}, \mathrm{Li}_{6} \mathrm{Zr}_{2} \mathrm{O}_{7}, \mathrm{Ba}_{8}\left(\mathrm{Me}_{6} \mathrm{Li}_{2}\right) \mathrm{O}_{24}$ $(\mathrm{Me}=\mathrm{Nb}, \mathrm{Ta}), \mathrm{Ba}_{10}\left(\mathrm{~W}_{6} \mathrm{Li}_{4}\right) \mathrm{O}_{20}$, and $\mathrm{K}_{x} \mathrm{Li}_{x} \mathrm{Ti}_{4-2 / x} \mathrm{O}_{8}$. The essential features of the structures are chains of occupied or vacant face-shared $\mathrm{MO}_{6}$ octahedra stacking along the hexagonal $c$-axis. Neighboring stacks of face shared octahedra only share corners. It was found that in compounds with $\mathrm{Li}$ contents equal to or greater than one in $\mathrm{Li}$-inserted $\mathrm{ReO}_{3}$, the $\mathrm{ReO}_{3}$ host lattice undergoes a twist about the shared corners of the $\mathrm{ReO}_{6}$ octahedra to accommodate the coordination preferred by the Li ions.

Another area of study was the search for suitable window materials for high-power infrared lasers. There was also a need for non-centrosymmetric crystals with large birefringence which may exhibit second harmonic generation and allow optical mixing in the infrared. Studies on heavy metal halides showed that mercurous chloride single crystals could be grown of a size and perfection suitable for prism polarizers with transmission to at least $16 \mu \mathrm{m}$ [53]. In addition, a study of the $\mathrm{TlCl}-\mathrm{PbCl}_{2}$ system was conducted and it was found that the compound $3 \mathrm{TlCl} \cdot \mathrm{PbCl}_{2}\left(\left(\mathrm{Tl}_{0.75} \mathrm{~Pb}_{0.25}\right)_{4} \mathrm{Cl}_{5}\right)$ which has a cation-disordered structure can enhance chloride ion conductivity by doping with $\mathrm{TlCl}$.

\section{Phase Equilibria and Crystallographic Studies of Dielectric/Microwave Materials}

\subsection{0s to Early 1990}

Roth and his coworkers started the investigation of the phase equilibria of dielectric materials in the 1950s. The main goal of these studies was to search for new materials with high dielectric constants and to understand the phase relationships and structural nature of these ceramic oxides. The required properties for ceramic 
microwave materials include high dielectric constant or permittivity, minimal dielectric loss (high quality factor, $Q$ ), and essentially zero temperature coefficient $\left(T_{\mathrm{f}}\right)$. These studies were focused on the tantalate, niobate, titanate and tungstate systems, and their chemistry with alkaline-earth and rare-earth oxides. The structure of most of these niobates, tantalates, and titanates consists of octahedral coordination that would likely produce high dielectric constants. Selected systems being studied from the fifties to the early $1990 \mathrm{~s}$ include $\mathrm{BaO}-\mathrm{TiO}_{2}$ [23], $\mathrm{BaO}-\mathrm{Nb}_{2} \mathrm{O}_{5}$ [54], $\mathrm{Nb}_{2} \mathrm{O}_{5}-\mathrm{WO}_{3}$ [55], $\mathrm{Ta}_{2} \mathrm{O}_{5}-\mathrm{TiO}_{2}$ [56], $\mathrm{Ta}_{2} \mathrm{O}_{5}-\mathrm{WO}_{3}$ [57], $\mathrm{Ta}_{2} \mathrm{O}_{5}-\mathrm{ZrO}_{2}$ [57], $\mathrm{ZrO}_{2}-\mathrm{Nb}_{2} \mathrm{O}_{5}$ [58], $\mathrm{Ta}_{2} \mathrm{O}_{5}-\mathrm{WO}_{3}-\mathrm{Al}_{2} \mathrm{O}_{3}$ [59], $\mathrm{ZrO}_{2}-\mathrm{TiO}_{2}$ [60], BaO$\mathrm{CoO}-\mathrm{O}-\mathrm{CO}_{2}$ [61], BaO-ZnO-TiO ${ }_{2}$ [62], BaO-TiO $2^{-}$ $\mathrm{Nb}_{2} \mathrm{O}_{5}[63,64]$, and $\mathrm{BaO}-\mathrm{Nd}_{2} \mathrm{O}_{3}-\mathrm{TiO}_{2}$ [65]. Of special importance was the discovery and structural analyses of the multiple phase formation (homologous series) of $\mathrm{Nb}_{2} \mathrm{O}_{5}$ with either $\mathrm{TiO}_{2}$ or $\mathrm{WO}_{3}[55,66]$ as opposed to the solid solution of these aliovalent ions previously proposed. This may be compared to the structural analysis of the incommensurate solid solution described for the systems of $\mathrm{Ta}_{2} \mathrm{O}_{5}$ with $\mathrm{TiO}_{2}$ and $\mathrm{WO}_{3}[56,57]$, as well as $\mathrm{ZrO}_{2}$ with $\mathrm{Nb}_{2} \mathrm{O}_{5}$ or $\mathrm{Ta}_{2} \mathrm{O}_{5}$ [58].

\subsection{1 ${\mathrm{BaO}-\mathrm{TiO}_{2}}_{2}$}

The phase diagram of the $\mathrm{BaO}-\mathrm{TiO}_{2}$ system determined by R. S. Roth et al. and his colleagues in 1974 [23] has provided key data for understanding and processing barium titanate dielectric ceramics important for wireless communications technology. Figure 5 shows the phase relationships in the $\mathrm{BaO}_{-} \mathrm{TiO}_{2}$ system for compositions with $>60 \%$ mole fraction $\mathrm{TiO}_{2}$. As a result of this work, four stable phases $\left(\mathrm{Ba}_{6} \mathrm{Ti}_{17} \mathrm{O}_{40}, \mathrm{Ba}_{4} \mathrm{Ti}_{13} \mathrm{O}_{30}\right.$, $\mathrm{BaTi}_{4} \mathrm{O}_{9}$, and $\mathrm{Ba}_{2} \mathrm{Ti}_{9} \mathrm{O}_{20}$ ) and two low temperature phases $\left(\mathrm{BaTi}_{2} \mathrm{O}_{5}\right.$ and $\left.\mathrm{BaTi}_{5} \mathrm{O}_{11}\right)$ were discovered. Commercial devices in the microwave industry often use the $\mathrm{BaTi}_{4} \mathrm{O}_{9}$ and $\mathrm{Ba}_{2} \mathrm{Ti}_{9} \mathrm{O}_{20}$ polytitanates as the major constituents in high frequency dielectric ceramics (i.e., microwave-filter devices). A full structural investigation was given for $\mathrm{Ba}_{4} \mathrm{Ti}_{13} \mathrm{O}_{30}$, and defect intergrowth of $\mathrm{Ba}_{2} \mathrm{Ti}_{9} \mathrm{O}_{20}$ [67] and $\mathrm{BaTi}_{5} \mathrm{O}_{11}[68]$ were characterized in detail.

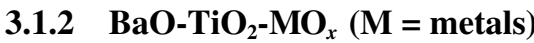

Most of microwave materials used nowadays are titanate based ceramics. Various ternary systems involving $\mathrm{BaO}$ and $\mathrm{TiO}_{2}$ have been studied due to the technical importance of both ferroelectric $\mathrm{BaTiO}_{3}$ and the microwave dielectric properties of the barium polytitanates, $\mathrm{BaTi}_{4} \mathrm{O}_{9}$ and $\mathrm{Ba}_{2} \mathrm{Ti}_{9} \mathrm{O}_{20}$. The ferroelectric properties of the $\mathrm{ABX}_{3}$ perovskites can be modified by

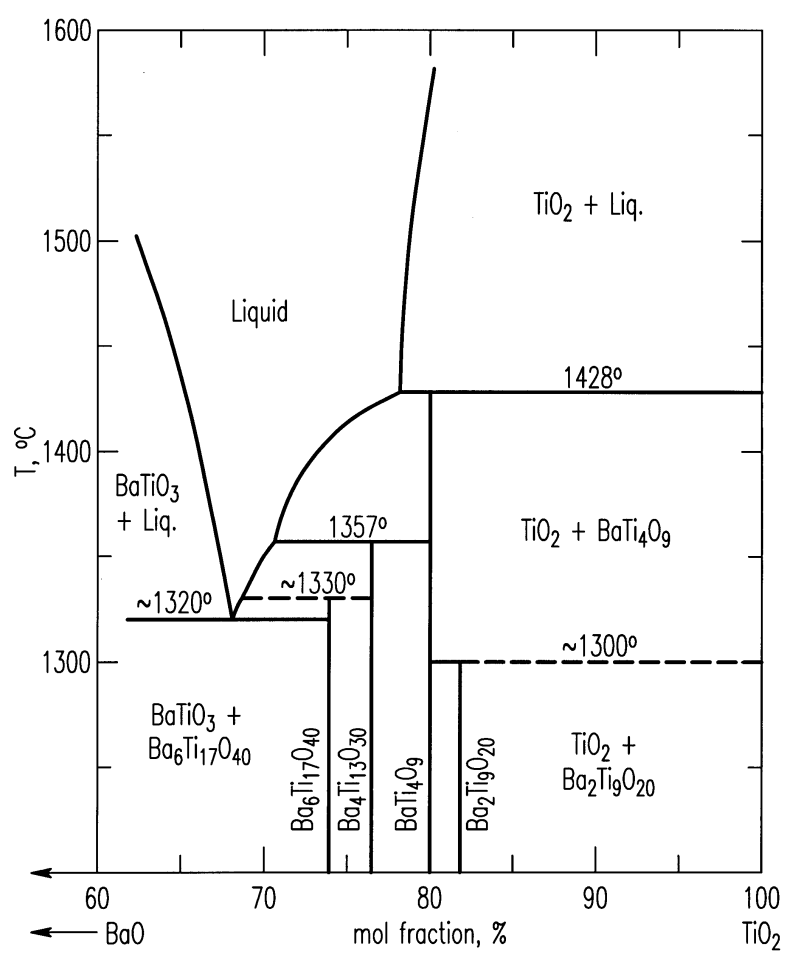

Fig. 5. Phase relations in the $\mathrm{BaO}-\mathrm{TiO}_{2}$ system for compositions with $>60 \%$ mole fraciton $\mathrm{TiO}_{2}$ [23]. Abbreviations and symbols used include: $\mathrm{BT}\left(\mathrm{BaTiO}_{3}\right) ; \mathrm{B}_{6} \mathrm{~T}_{17}\left(\mathrm{Ba}_{6} \mathrm{Ti}_{17} \mathrm{O}_{40}\right) ; \mathrm{B}_{4} \mathrm{~T}_{13}\left(\mathrm{Ba}_{4} \mathrm{Ti}_{13} \mathrm{O}_{30}\right) ; \mathrm{BT}_{4}$ $\left(\mathrm{BaTi}_{4} \mathrm{O}_{9}\right) ; \mathrm{B}_{2} \mathrm{~T}_{9}\left(\mathrm{Ba}_{2} \mathrm{Ti}_{9} \mathrm{O}_{20}\right) ; \mathrm{L}$ (liquid); (•) solid phases, quenched; (o) melted, quenched.

incorporation of other ions in solid solution and vacancy distribution on selected atomic sites of the structure. The dielectric properties of phases are additive so that the inclusion of one or more other phases in equilirium with the polytitanates can be used to modify the electronic properties of dielectric ceramics. Practically all ceramic components are processed as mixtures, that is, with controlled amounts of second phases to achieve a net-overall zero temperature coefficient. Because of the technological importance of these systems, a review of the phase equilibria and crystal chemistry of the binary and ternary barium polytitanates involving the addition of mostly aliovalent ions to barium polytitanates has been reported by Roth et al. [62]. In this review, an extensive discussion of the fundamental crystal chemistry and crystal structures of various polytitantes have also been given. The various binary and ternary systems discussed included $\mathrm{BaO}-\mathrm{ZnO}, \mathrm{ZnO}-\mathrm{TiO}_{2}, \mathrm{BaO}-\mathrm{TiO}_{2}$, $\mathrm{BaO}-\mathrm{TiO}_{2}-\mathrm{ZrO}_{2}, \quad \mathrm{BaO}-\mathrm{TiO}_{2}-\mathrm{Al}_{2} \mathrm{O}_{3}, \quad \mathrm{BaO}-\mathrm{TiO}_{2}-\mathrm{MgO}$, $\mathrm{BaO}-\mathrm{TiO}_{2}-\mathrm{Nb}_{2} \mathrm{O}_{5}, \mathrm{BaO}-\mathrm{TiO}_{2}-\mathrm{ZnO}$. Among these systems, two are highlighted in the following. 


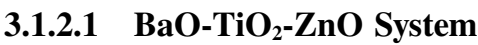

The phase diagram of the $\mathrm{BaO}-\mathrm{TiO}_{2}-\mathrm{ZnO}$ system was of interest (Fig. 6) because it was reported that the composition $\mathrm{Ba}_{3} \mathrm{Ti}_{12} \mathrm{Zn}_{7} \mathrm{O}_{34}$ has a positive temperature coefficient of the dielectric constant, and therefore can be used to compensate the negative coefficient in ceramic specimens of $\mathrm{BaTi}_{4} \mathrm{O}_{9}$ [62]. No solid solution of $\mathrm{ZnO}$ in any of the binary barium polytitanates was observed. The system contains at least four ternary phases: $\mathrm{Ba}_{\mathrm{x}} \mathrm{Zn}_{\mathrm{x}} \mathrm{Ti}_{8-\mathrm{x}} \mathrm{O}_{16}$ with the Hollandite structure, $\mathrm{Ba}_{4} \mathrm{ZnTi}_{11} \mathrm{O}_{27}, \mathrm{Ba}_{2} \mathrm{ZnTi}_{5} \mathrm{O}_{13}$, and $\mathrm{BaZn}_{2} \mathrm{Ti}_{4} \mathrm{O}_{11}$. The structure of $\mathrm{Ba}_{4} \mathrm{ZnTi}_{11} \mathrm{O}_{27}$ and $\mathrm{Ba}_{2} \mathrm{ZnTi}_{5} \mathrm{O}_{13}$ were investigated at NIST by the single crystal $\mathrm{x}$-ray technique.

The projection of the structure of $\mathrm{Ba}_{2} \mathrm{ZnTi}_{5} \mathrm{O}_{13}$ along the $b$-axis is shown in Fig. 7 (Monoclinic $C 2 / m$, $a=15.236(2) \AA, b=3.8992(7) \AA, c=9.139(2) \AA$, $\beta=98.78(2) \AA$ ). This compound, which was found to be isostructural with $\mathrm{K}_{2} \mathrm{Ti}_{6} \mathrm{O}_{13}$, crystallizes in the form of thin sheets. The short $b$-axis corresponds to the axial $\mathrm{O}-\mathrm{Ti}-\mathrm{O}$ distance in a $\mathrm{TiO}_{6}$ octahedron. The opened structure can be described as consisting of zigzag ribbons of $(\mathrm{Ti}, \mathrm{Zn}) \mathrm{O}_{6}$ octahedra running along $c$. Each repeating unit in these ribbons comprises of a set of three edge-sharing octahedra connected to three other edge- sharing octahedra at a level of one-half unit cell down (and up) along $b$. Rectangular open channels of approximate size $3.2 \AA$ by $2.9 \AA$ can be seen running parallel to $b$. Zn was found to substitute partially for $\mathrm{Ti}$ in octahedral sites in this structure.

The overall structure of $\mathrm{BaZn}_{2} \mathrm{Ti}_{4} \mathrm{O}_{11}$ (Orthorhombic Pbcn, $a=14.140$ (3) $\AA, \quad b=11.592 \quad$ (2) $\AA$, and $c=11.1173$ (13) $\AA$ ) consists of a three-dimensional network of distorted, edge-sharing and corner-sharing octahedra with $\mathrm{Zn}$ filling some tetrahedral interstices. Ti atoms were found to occupy only octahedral positions. Similar to $\mathrm{Ba}_{2} \mathrm{ZnTi}_{5} \mathrm{O}_{13}, \mathrm{Zn}$ atoms were also found to occupy both tetrahedral and octahedral sites. Figure 8 shows the arrangement of idealized $\mathrm{TiO}_{6}$ and $\mathrm{ZnO}_{6}$ octahedra and $\mathrm{ZnO}_{4}$ tetrahedra in each level of $y(=n / 6$, $n=1,2,3, \ldots 6)$ viewed along the $b$-axis. There is a substantially different arrangement at each level. No $\mathrm{ZnO}_{4}$ or $\mathrm{ZnO}_{6}$ units share polyhedral corners or edges.

\subsubsection{2 $\mathrm{BaO}-\mathrm{TiO}_{2}-\mathrm{Nb}_{2} \mathrm{O}_{5}$ System}

In the ternary $\mathrm{BaO}-\mathrm{TiO}_{2}-\mathrm{Nb}_{2} \mathrm{O}_{5}$ system $[63,64]$, a total of fourteen ternary compounds have been identified. Based upon compositions containing high $(\mathrm{Ti}+\mathrm{Nb}) / \mathrm{Ba}$ ratios, four of them were expected to have dielectric

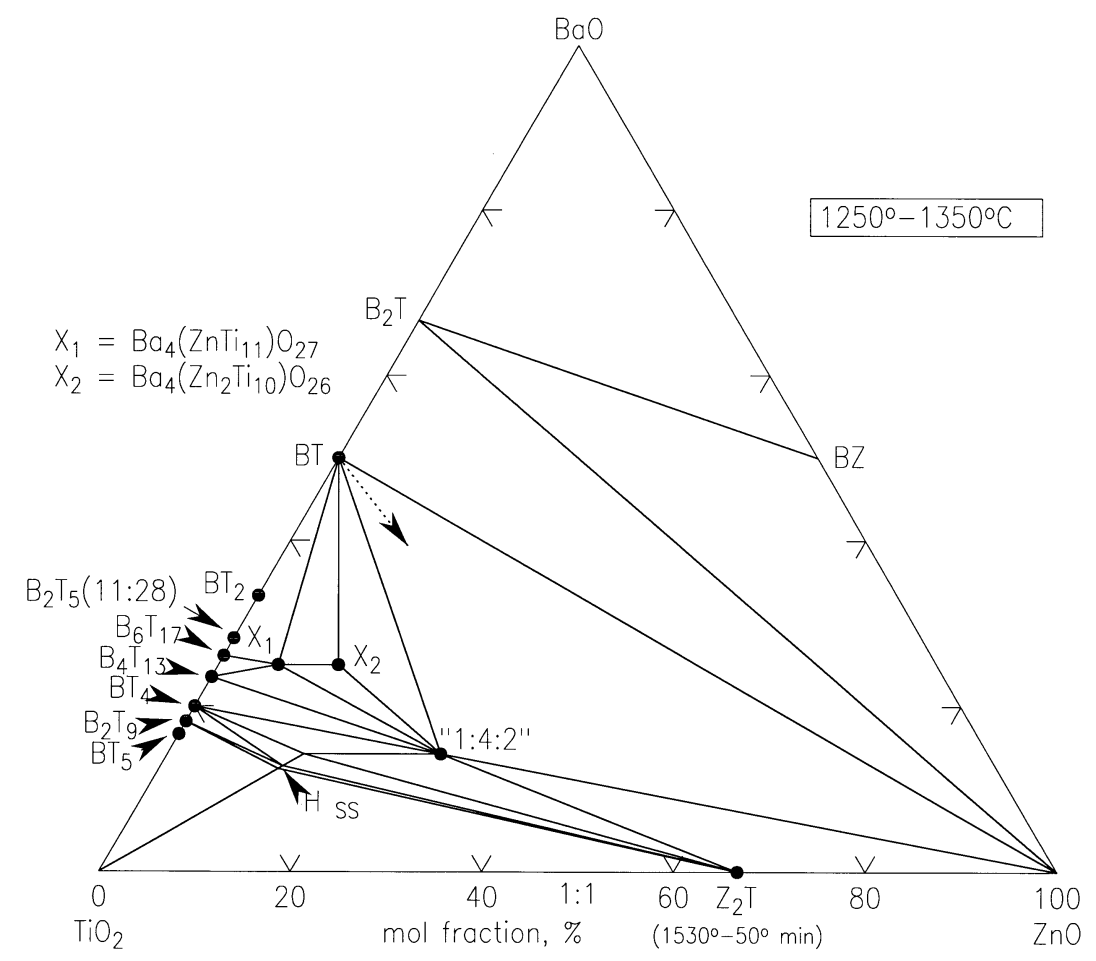

Fig. 6. Phase Equilibria diagram of the system $\mathrm{BaO}_{-} \mathrm{TiO}_{2}-\mathrm{ZnO}$ [62]. Filled circles represent compounds stable at $1250{ }^{\circ} \mathrm{C}$. Open circles represent compositions of most of the specimens prepared for the study. Dotted arrow represents the apparent direction of the maximum amount of solid solution of $\mathrm{ZnO}$ in $\mathrm{BaTO}_{3}$. 


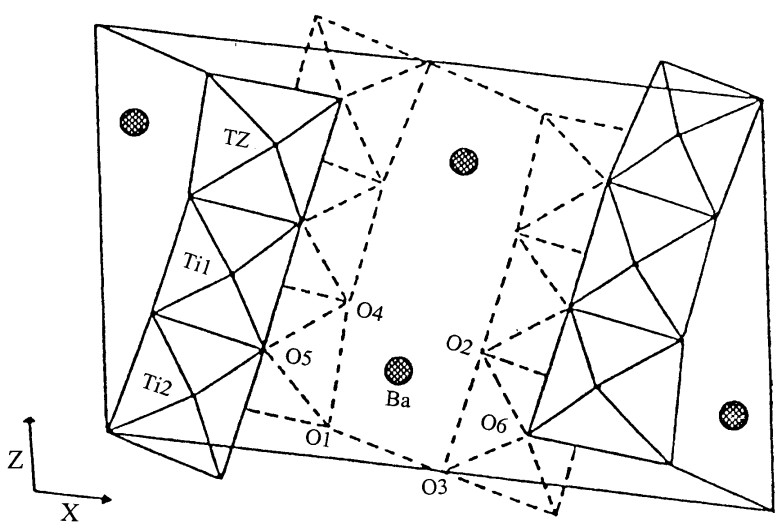

Fig. 7. Structure of $\mathrm{Ba}_{2} \mathrm{ZnTi}_{5} \mathrm{O}_{13}$ [62]. $\mathrm{TZ}$ is used to indicate the mixed (Ti, $\mathrm{Zn})$ site.

properties comparable to those of the polytitanates of barium. These are members of a chemically and structurally homologous series, $\mathrm{AB}_{2 n+1} \mathrm{O}_{4 n+5}$ with $3<n<6$ with respective compositions of $\mathrm{BaTi}_{3} \mathrm{Nb}_{4} \mathrm{O}_{17}$, $\mathrm{BaTi}_{5} \mathrm{Nb}_{4} \mathrm{O}_{21}, \mathrm{BaTi}_{7} \mathrm{Nb}_{4} \mathrm{O}_{25}$, and $\mathrm{BaTi}_{9} \mathrm{Nb}_{4} \mathrm{O}_{29}$. The phase $\mathrm{BaTiNb}_{4} \mathrm{O}_{13}$ which could be considered as a $n=2$ member of the chemical series, has a different type of structure, isomorphous to $\mathrm{KTa}_{5} \mathrm{O}_{13}$. It was also found that a small amount of $\mathrm{Nb}_{2} \mathrm{O}_{5}$ (mole fraction of $1 \%$ to $5 \%$ ) is enough to change the stability for the closepacked layers of the Ba-polytitanate phases, $\mathrm{Ba}_{6} \mathrm{Ti}_{7} \mathrm{O}_{40}$ and $\mathrm{Ba}_{4} \mathrm{Ti}_{13} \mathrm{O}_{30}$ so that four new phases (having 8-layer orthorhombic, 20-layer orthorhombic, 7-layer monoclinic, and 13-layer monoclinic lattices) form instead. All these barium niobium polytitanates have the 6-octahedra wide $(\approx 17 \AA$ A type unit cell. Detailed structure determination of some of the phases continues today.

\subsection{3 $\mathrm{BaO}-\mathrm{R}_{2} \mathrm{O}_{3}-\mathrm{TiO}_{2}(\mathrm{R}=$ lanthanides $)$}

In the late 1970s and early 1980s, a composition close to $1: 1: 5$ in the $\mathrm{BaO}: \mathrm{Nd}_{2} \mathrm{O}_{3}: \mathrm{TiO}_{2}$ system was identified to having high dielectric constants (80 to 90 ), modest Q (3 to $4 \mathrm{~K}$ at $3 \mathrm{GHz}$ ), and near zero temperature coefficient of resonance frequency. Therefore dielectric ceramics based on this system have found important applications in modern electronic practices. The phase diagram of this system was determined by Kolar et al. [65]. Characterization of new phases in the $\mathrm{BaO}-\mathrm{R}_{2} \mathrm{O}_{3}-\mathrm{TiO}_{2}$ systems has become important research activities since. For example, Olsen and Roth [69] determined the crystal structure of $\mathrm{BaNd}_{2} \mathrm{Ti}_{3} \mathrm{O}_{10}$ by electron diffraction and high-resolution electron microscopy to be monoclinic instead of the reported orthorhombic symmetry. The lower symmetry found was due to the octahedral tilt because of the relatively small $\mathrm{Nd}^{3+}$ cations. Crystal symmetry and lattice parameters of two other new phases, $\mathrm{BaNd}_{2} \mathrm{Ti}_{3} \mathrm{O}_{10}$, and $\mathrm{BaNd}_{2} \mathrm{Ti}_{5} \mathrm{O}_{14}$, have also been identified by single crystal growth [65].

In another study, the structure of the $\mathrm{Ba}_{6-3 x} \mathrm{Sm}_{8+2 x} \mathrm{Ti}_{18} \mathrm{O}_{54}$ solid solution was determined to be different from reported data due to the observation of superstructure reflections [70]. The structure, refined as orthorhombic Pnma and with a doubled $c$-axis (7.6(1) $\AA$ ), is made up of a network of corner sharing $\mathrm{TiO}_{6}{ }^{-2}$ octahedra creating rhombic (perovskite-like) and pentagonal channels. While the two pentagonal channels are fully occupied by the $\mathrm{Ba}$ atoms, and one rhombic channel is fully occupied by $\mathrm{Sm}$, in the remaining two rhombic channels, one is partially occupied by $\mathrm{Sm}$ and the other one is shared by $\mathrm{Ba} / \mathrm{Sm}$ atoms.
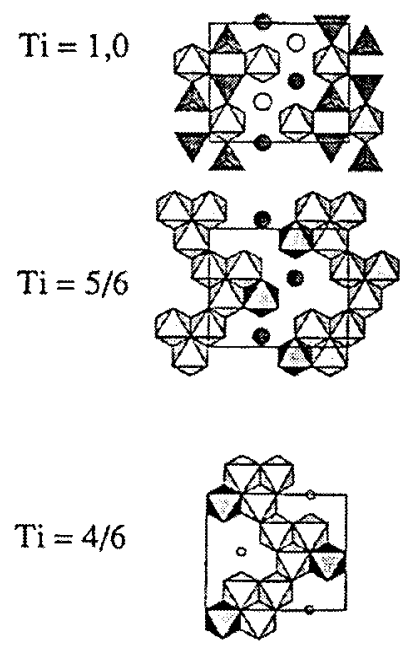
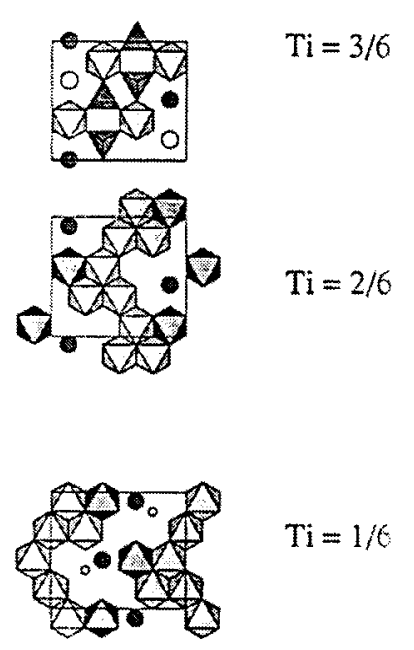

Fig. 8. Ideal representation of the crystal structure of $\mathrm{BaZn}_{2} \mathrm{Ti}_{4} \mathrm{O}_{11}$ at the six (Ti, $\left.\mathrm{Zn}\right)$ levels of the unit cell [62]. Dark triangles represent $\mathrm{ZnO}_{4}$ polyhedra pointing up ad down and dark octahedra represent the " $\mathrm{ZnO}_{6}$ " octahedra. 


\subsection{Early 1990s to Present}

Wireless communication has been a fast growing industry in recent years. Various applications include wireless FAX, cell phones, global position satellite (GPS), and direct broadcast satellites. Dielectric ceramics are used to make a variety of components in cellular communications circuits, such as resonators, oscillators, and bandpass filters for wireless communications. Relatively few ceramic systems are currently available with the properties needed for practical applications at various operating frequencies. For further miniaturization, new materials are still required.

Since the early nineties, the focus of the phase equilibrium studies of dielectrics at NIST has been on ceramic materials that are for wireless microwave communication applications. This microwave phase equilibria program is under the direction of Terrell Vanderah. Team members include R. S. Roth, I. Levin, B. Burton, E. Cockayne, W. Wong-Ng, J. Chan (now at the Chemistry Department of Louisiana State University), and A. Drews (now at the Ford Motor Research Laboratory). Collaborators at the NIST Neutron Reactor Division include B. Toby, A. Santoro, Q. Huang, and T. Amos. T. Siegrist of Lucent Technologies participates in determining single crystal structures. Since dielectric property is critical for determining the applications of these materials, property measurement is also an integral part of the program. Further collaboration also involves R. Geyer of NIST, Boulder, who conducts dielectric property measurements.

In addition to the studies of the titanate systems, research interest also extended to the tantalate and niobate systems. Up to today, representative oxide systems that have been pursued at NIST include $\mathrm{BaO}-\mathrm{Fe}_{2} \mathrm{O}_{3}-\mathrm{TiO}_{2}$ [71], $\mathrm{SrO}-\mathrm{TiO}_{2}-\mathrm{Nb}_{2} \mathrm{O}_{5}$ [72], $\mathrm{SrO}-\mathrm{Al}_{2} \mathrm{O}_{3}-\mathrm{Nb}_{2} \mathrm{O}_{5}$ [73], $\mathrm{CaO}-\mathrm{Al}_{2} \mathrm{O}_{3}-\mathrm{Nb}_{2} \mathrm{O}_{5}$ [74] and $\mathrm{BaO}-\mathrm{Al}_{2} \mathrm{O}_{3}-\mathrm{Nb}_{2} \mathrm{O}_{5}$ [75], as well as work on $\mathrm{CaO}-\mathrm{SrO}$ and $\mathrm{BaO}-\mathrm{Ta}_{2} \mathrm{O}_{5}$ systems with and without $\mathrm{TiO}_{2}$. Of special note is the structure determination of the various polytypes of $\mathrm{Ca}_{2} \mathrm{Ta}_{2} \mathrm{O}_{7}$ [76].

\subsubsection{The $\mathrm{BaO}-\mathrm{Fe}_{2} \mathrm{O}_{3}-\mathrm{TiO}_{2}$ System}

Ceramic magnetic oxides are essential components in a wide variety of electronic applications; for example, signal circulators and isolators. In the hope of obtaining improved materials that have higher dielectric constants while maintaining low dielectric losses and high saturation magnetization, phase equilibrium study of the $\mathrm{BaO}-$ $\mathrm{Fe}_{2} \mathrm{O}_{3}-\mathrm{TiO}_{2}$ system [71] was conducted to investigate the phase relations and crystal-chemical relations of magnetic iron-containing compounds with the technically important barium polytitanates. The phase relationships of this system was found to be very complex (Fig. 9).
The overview of the binary systems and the phase relationships of the ternary system were discussed in detail. The system $\mathrm{BaTiO}_{3}-\mathrm{Ba}_{2} \mathrm{Fe}_{2} \mathrm{O}_{5}$ was found to contain tetravalent $\left(\mathrm{Fe}^{+4}\right)$ ions when annealed at low temperatures and the oxidation/reduction and structural analysis was thoroughly investigated [77]. There are at least 16 ternary phases in the $\mathrm{BaO}-\mathrm{Fe}_{2} \mathrm{O}_{3}-\mathrm{TiO}_{2}$ system, with 10 adopting new structure-types. Among them, crystal structure determination has been performed on the following phases: $\mathrm{Ba}_{3} \mathrm{Fe}_{10} \mathrm{TiO}_{20}$ [78], $\mathrm{Ba}_{2} \mathrm{Fe}_{2} \mathrm{Ti}_{4} \mathrm{O}_{13}$ [78], $\mathrm{Ba}_{6} \mathrm{Fe}_{45} \mathrm{Ti}_{17} \mathrm{O}_{106}$ [79], $\mathrm{BaFe}_{11} \mathrm{Ti}_{3} \mathrm{O}_{23}$ [79], $\mathrm{Ba}_{4} \mathrm{Fe}_{2} \mathrm{Ti}_{10} \mathrm{O}_{27}$ [78], $\mathrm{Ba}_{11} \mathrm{Fe}_{8} \mathrm{Ti}_{9} \mathrm{O}_{41}$ [80], and $\mathrm{Ba}_{5} \mathrm{Fe}_{4} \mathrm{Ti}_{10} \mathrm{O}_{31}$ [81]. Most of these phases exhibit layers of closed-packed structure built from $[\mathrm{O},(\mathrm{Ba}, \mathrm{O})]$ layers. One common feature of these structure is that the octahedral sites are mostly occupied by a mixture of $\mathrm{Fe}^{3+}$ and $\mathrm{Ti}^{4+}$ (occasionally with preferential ordering). Tetrahedral sites are occupied by $\mathrm{Fe}^{3+}$ only. Five examples of these structures are highlighted below.

\subsubsection{1 $\mathrm{Ba}_{3} \mathrm{Fe}_{10} \mathrm{TiO}_{20}$}

$\mathrm{Ba}_{3} \mathrm{Fe}_{10} \mathrm{TiO}_{20}$ has a relatively high Fe-content and adopts an open-framework type structure (Fig. 10) [78]. Both tetrahedral and octahedral coordination of the transition metals are featured. The rectangular and pentagonal channels are occupied by the barium ions. $\mathrm{Ba}_{3} \mathrm{Fe}_{10} \mathrm{TiO}_{20}(I 2 / m, a=15.358(1) \AA, b=11.818(1) \AA$, $c=5.177(3) \AA$, and $\beta=91.231(4)^{\circ}$ is isostructural with $\mathrm{Ba}_{3} \mathrm{Fe}_{10} \mathrm{SnO}_{20}, \quad \mathrm{Ba}_{3} \mathrm{Al}_{10} \mathrm{TiO}_{20}, \quad \mathrm{~Pb}_{3} \mathrm{Al}_{10} \mathrm{GeO}_{20}$ and $\mathrm{Pb}_{3} \mathrm{Al}_{10} \mathrm{SiO}_{20}$ [78]. At room temperature, the compound has a magnetically ordered lattice with reduced symmetry and two antiferromagnetic sublattices. The polyhedral linkage among the magnetic sites is shown in Fig. 11. Fe1 and Fe4 comprise one set of collinear antiparallel spins in the vertex-linked tetrahedra. Magnetic interactions occur via superexchange. Another set of antiparallel spins are located in the edge-sharing $\mathrm{Fe} 2-\mathrm{Fe} 3$ octahedral sites. Direct interactions across shared edges are possible in addition to $90^{\circ}$ superexchange via oxygen. The magnetic susceptibility plot as a function of temperature after zero field cooling and field cooling is shown in Fig. 12. Interactions among magnetic ions are substantial. These susceptibility curves indicate transitions at $5 \mathrm{~K}$ and $45 \mathrm{~K}$. Data collected at $15 \mathrm{~K}, 6.5 \mathrm{~K}$, and $1.8 \mathrm{~K}$ indicated that at least one other magnetic structure occurs below room temperature.

\subsubsection{2 $\mathrm{Ba}_{6} \mathrm{Fe}_{45} \mathrm{Ti}_{17} \mathrm{O}_{106}$ and $\mathrm{BaFe}_{11} \mathrm{Ti}_{3} \mathrm{O}_{23}$}

The overall structure of $\mathrm{Ba}_{6} \mathrm{Fe}_{45} \mathrm{Ti}_{17} \mathrm{O}_{106}(C 2 / m$, $a=19.390(1) \AA, b=20.260(1) \AA, c=10.076(1) \AA$, $\left.\beta=105.27(1)^{\circ}\right)$ was solved with the single crystal diffraction method, and the exact stoichiometry was studied 


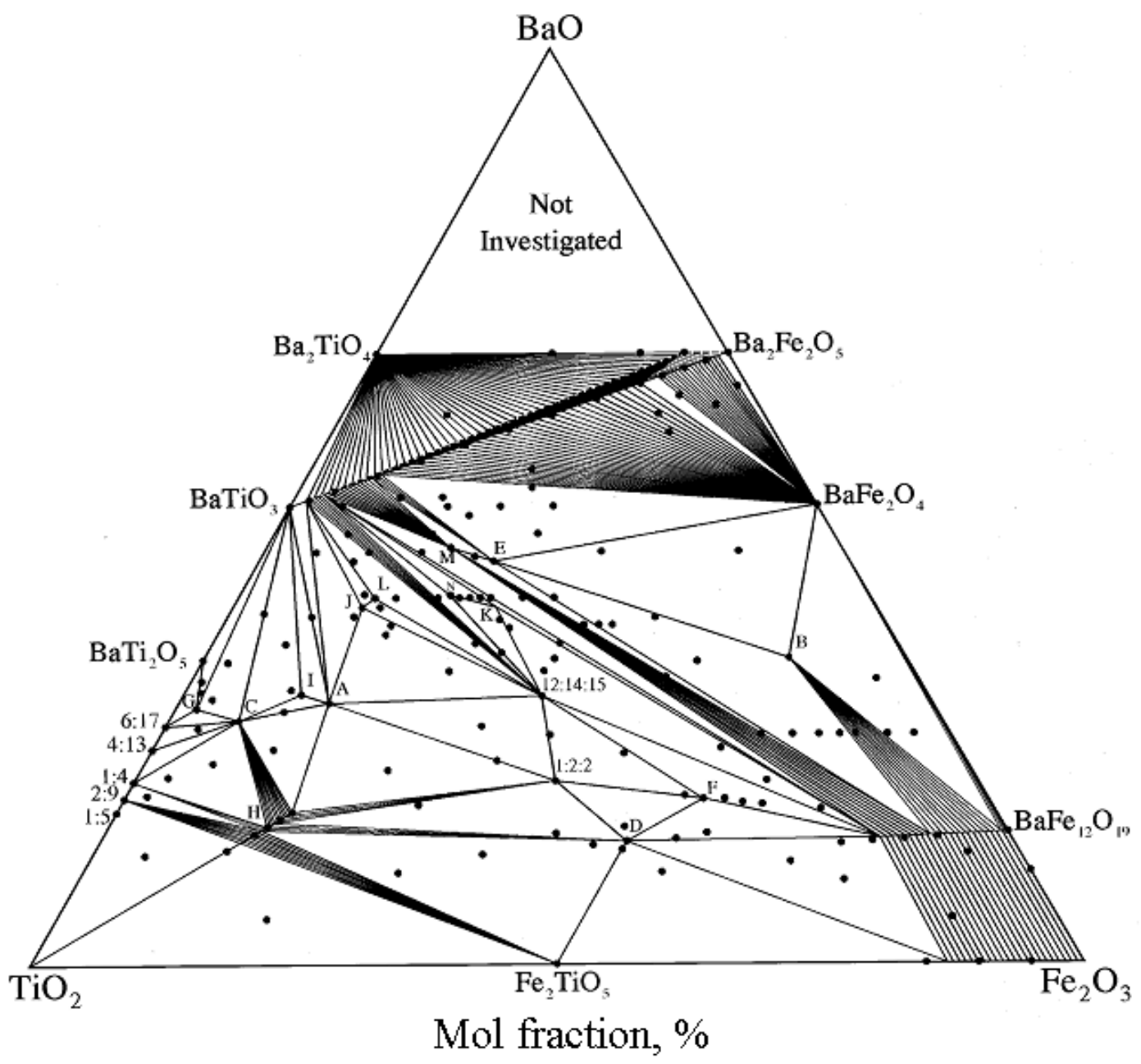

Fig. 9. $\mathrm{BaO}-\mathrm{Fe}_{2} \mathrm{O}_{3}-\mathrm{TiO}_{2}$ phase diagram (air, $1250{ }^{\circ} \mathrm{C}$ to $1270{ }^{\circ} \mathrm{C}$ ) [72]. The compositions of the ternary phases found in the system are $\left(\mathrm{BaO}: \mathrm{Fe}_{2} \mathrm{O}_{3}: \mathrm{TiO}_{2}\right)$ : A, 2:1:4; B,3:5:1; C,4:1:10; D,3:12:7; E, 4:2:3; F, 1:6:3; G, 14:1:35; H 1:1:5 and 1:1:4 (Hollandite); I, 8:3:16; J, 3:1:4; K, 8:5:8; L, 6:2:7; M, 8:3:6;, N, 2:1:2.

by neutron Rietveld refinements [79]. This compound exhibits variable stoichiometry, $\mathrm{Ba}_{6} \mathrm{Fe}_{48-x} \mathrm{Ti}_{14+x} \mathrm{O}_{106}$, with Fe:Ti ratio dependent upon the partial pressure of oxygen. The $x$ value is 3 when prepared in air, and approaches ' 0 ' when prepared in $100 \% \mathrm{O}_{2}$. It is a partially reduced phase with three $\mathrm{Fe}^{2+}$ per formula. The structure of $\mathrm{Ba}_{6} \mathrm{Fe}_{45} \mathrm{Ti}_{17} \mathrm{O}_{106}$ as viewed approximately along the $c$-axis, drawn to emphasize the stacking sequence of the close-packed $[\mathrm{O},(\mathrm{Ba}, \mathrm{O})]$ layers, is shown in Fig. 13. This eight-layer close-packed structure is built from alternating $c c p$ and $h c p$ layers [stacking sequence $(\mathrm{ch})_{4}$ ] along the $a$-direction. Despite the high $\mathrm{Fe}$ content, it is a weak magnetic compound due to antiferromagnetic-type interactions.

During the crystal growth experiments of $\mathrm{Ba}_{6} \mathrm{Fe}_{45} \mathrm{Ti}_{17} \mathrm{O}_{106}$, a co-product crystal was also obtained, which is metastable in air (could not be prepared as a polycrystalline sample when cooled from above the solidus). The structure of this phase, $\mathrm{BaFe}_{11} \mathrm{Ti}_{3} \mathrm{O}_{23}(C 2 /$ $c, a=19.561(1) \AA, b=8.6614(7) \AA, c=10.120(1) \AA$, $\left.\beta=105.62(1)^{\circ}\right)$ was found to be related to but simpler than that of $\mathrm{Ba}_{6} \mathrm{Fe}_{45} \mathrm{Ti}_{17} \mathrm{O}_{106}$ (Fig. 14). It has the same stacking sequence, and has exactly the same number of layers as that of $\mathrm{Ba}_{6} \mathrm{Fe}_{45} \mathrm{Ti}_{17} \mathrm{O}_{106}$, but with a smaller $b$-dimension. This compound is also partially reduced, with $1 \mathrm{~mol}$ of $\mathrm{Fe}^{2+}$ per formula unit. The structure has some interesting features that may relate to its metastable nature. It has pairs of very unusual edgesharing tetrahedra (Fig. 15). The expected cation-cation repulsion effects are observed in elongated Fe7-O3 distances with Fe displaced away from the common tetrahedral O3-O3 edge. Four out of eight close-pack layers in the structure are Ba-free. 


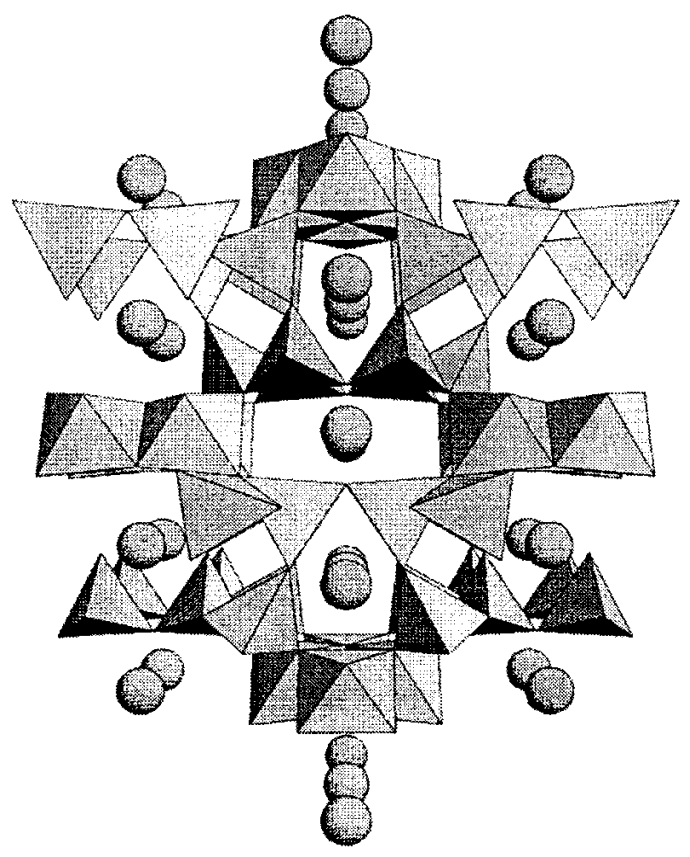

Fig. 10. The monoclinic crystal structure of $\mathrm{Ba}_{3} \mathrm{Fe}_{10} \mathrm{TiO}_{20}$ (3:5:1) [78], perspective view approximately along the $c$-direction. Large spheres are Ba cations.

\subsubsection{3 $\quad \mathrm{Ba}_{11} \mathrm{Fe}_{8} \mathrm{Ti}_{9} \mathrm{O}_{41}$}

This phase has an exceptionally long $c$-axis $\left(\mathrm{Pb}_{3} /\right.$ $m m c, a=5.7506(3) \AA, c=61.413(2) \AA)$ and therefore presented a crystallographic challenge [80]. The structure consists of 26 close-packed [O, $\mathrm{Ba}, \mathrm{O})]$ layers (Fig. 16) with a stacking sequence ( (hchlchchchc $)_{2}$. The magnetic $\mathrm{Fe}$ ions were found to concentrate within four contiguous $c p$ layers around $z=1 / 4$ and $3 / 4$. Unusual structural features, including cation disorder associated with unreasonably short cation-cation separations, were observed to occur within magnetic sections of the structure. This portion of the structure has been referred to as 'natural magnetic multilayers'. Preferential ordering of $\mathrm{Fe}$ and $\mathrm{Ti}$ were found in the octahedral sites.

\subsubsection{4 $\mathrm{Ba}_{5} \mathrm{Fe}_{4} \mathrm{Ti}_{10} \mathrm{O}_{31}$}

This phase also has a relatively long $c$-axis $\left(\mathrm{P}_{3} /\right.$ $m c m, a=9.9886(2) \AA, c=42.226(2) \AA ; Z=6$ ). It crystallizes in 18-layer close-packed structure built from vacancy-free $[\mathrm{O},(\mathrm{Ba}, \mathrm{O})]$ layers (Fig. 17) [81]. Preferential ordering of $\mathrm{Fe}^{3+}$ and $\mathrm{Ti}^{4+}$ was found in the octahedral sites. The tetrahedral sites are occupied by $\mathrm{Fe}^{3+}$, and one of which shares faces and is half occupied. Some Ba
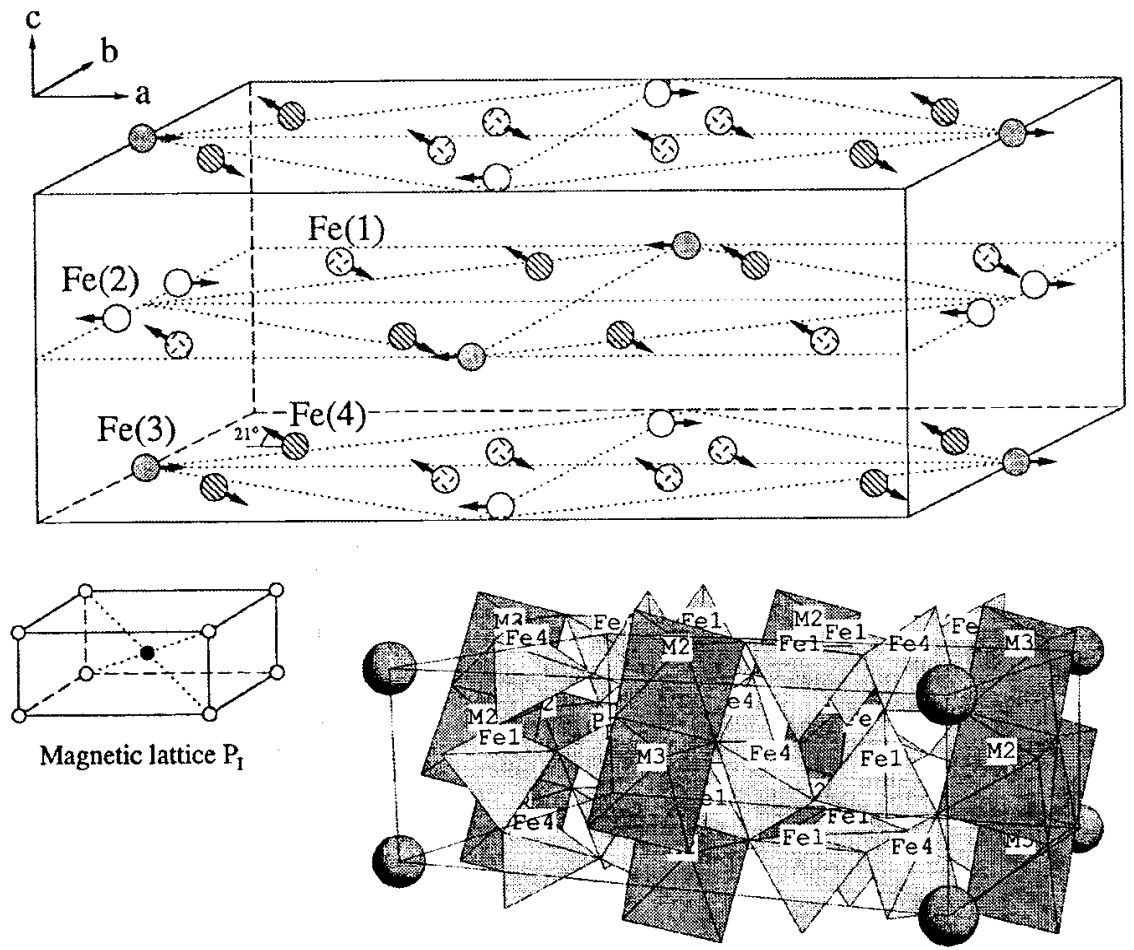

Fig. 11. The magnetic structure model for $\mathrm{Ba}_{3} \mathrm{Fe}_{10} \mathrm{TiO}_{20}$ from room temperature structure study. The magnetic lattice exhibits $P / 2^{\prime}$ symmetry and is antibody-centered. The polyhedron linkage patterns among the magnetic sites are illustrated in the bottom part of the figure. Fe1 and Fe4 comprise one set of spins while M2 and M3 comprise the second set [78]. 


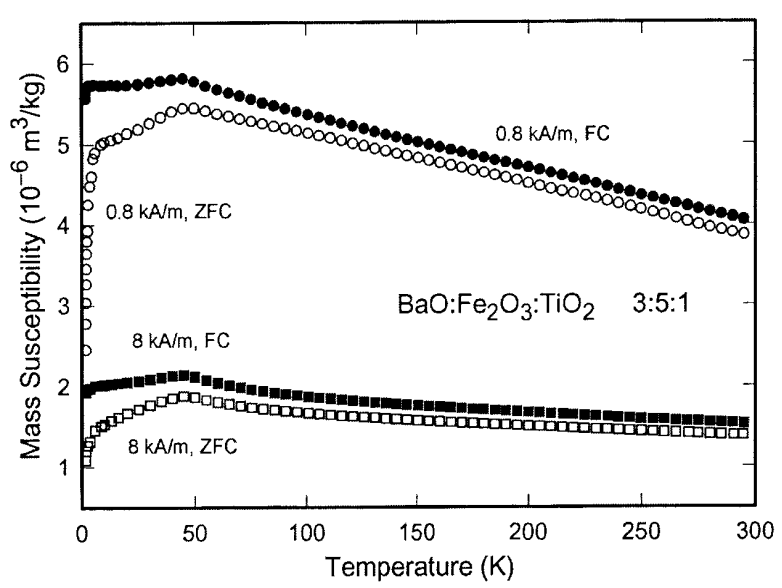

Fig. 12. Magnetic susceptibility plot of $\mathrm{Ba}_{3} \mathrm{Fe}_{10} \mathrm{TiO}_{20}$ [78].

ions in the structure displays $(9+3)$ coordination with three unusually long Ba-O bond distances. The structure contains residual strain not relieved by distortion. The compound exhibits approximately paramagnetic behavior with small deviations from the Curie Law. The relative permittivity and dielectric loss tangent values (measured between $7.1 \mathrm{GHz}$ and $7.7 \mathrm{GHz}$ ) were $32 \times 10^{-3}$ and $3.3 \times 10^{-3}$, respectively.

\subsubsection{The $\mathrm{SrO}-\mathrm{Nb}_{2} \mathrm{O}_{5}-\mathrm{TiO}_{2}$ System}

The cubic $\mathrm{SrTiO}_{3}$ phase has a high dielectric constant but a negative temperature coefficient. This is a poten- tially useful microwave ceramic that requires secondphase compensation. During the phase equilibria studies, more than 15 ternary compounds have been confirmed. Documentation of the phase diagram of this system is currently in progress [72]. The crystal structure of various homologous series have been investigated in this laboratory. Three such series will be highlighted. Two series feature perovskite slabs while the third one consists of rutile slabs.

The first perovskite homologous series can be described with the formula of $\mathrm{A}_{n} \mathrm{~B}_{n} \mathrm{O}_{3 n+2}(\mathrm{~A}=\mathrm{Sr} ; \mathrm{B}=\mathrm{Ti}$, $\mathrm{Nb}$ ). The structure of the $n=5$ member (Fig. 18) [82] consists of alternating perovskite slabs built from five layers of distorted octahedra. Each slab is offset with respect to each other by $a / 2$ and $c / 2$. All atoms are found to be on the mirror planes at $z=0$ and $1 / 2 . \mathrm{Nb}^{5+}$ was found to be associated with highly distorted octahedra near the gap of the block, whereas the largest amount of $\mathrm{Ti}^{4+}$ is found in the center of the slabs, where octahedral distortion is the least.

The compounds of the perovskite homologous series $\mathrm{A}_{n} \mathrm{~B}_{n-1} \mathrm{O}_{3 n}$ have a rhombohedral structure, and the thickness of the slab is $(n-1)$ units of octahedra [83]. The crystal structure of the $n=6$ member viewed along the $\langle 110\rangle$ direction is shown in Fig. 19. It consists of infinite perovskite-type slabs with five octahedra in thickness. $\mathrm{Sr}$ atoms are shown as spheres. $\mathrm{Ti}^{4+}$ and $\mathrm{Nb}^{5+}$ are distributed among the octahedral sites. All $\mathrm{Sr}$ ions are 12-coordinated. Similar to the previous perovskite series, octahedral sites have mixed $\mathrm{Nb}^{5+}$ and $\mathrm{Ti}^{4+}$ ions with

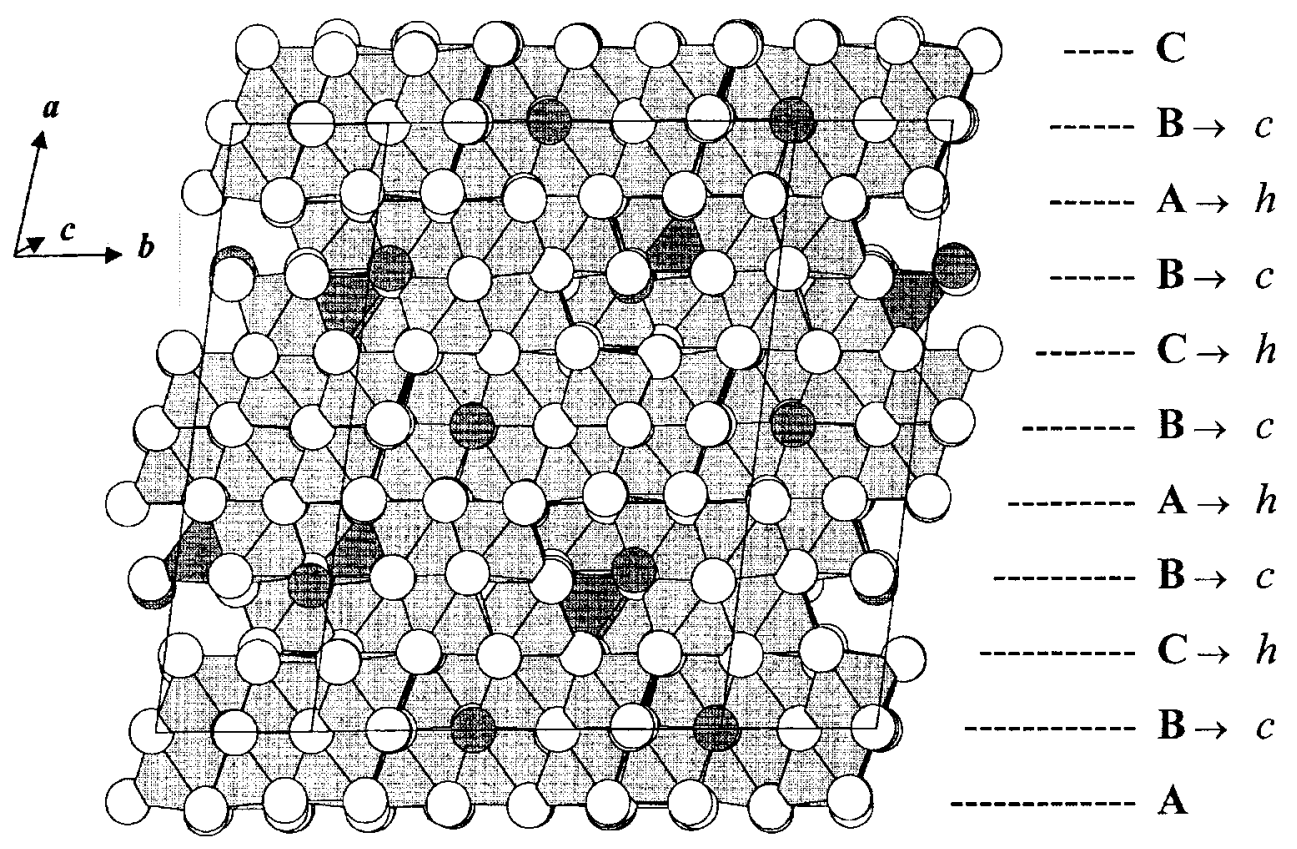

Fig. 13. The structure of $\mathrm{Ba}_{6} \mathrm{Fe}_{45} \mathrm{Ti}_{17} \mathrm{O}_{106}$ as viewed approximately along the $c$-direction [79]. Successive layers alternate between $c c p$ and $h c p$ along the $a$-axis, resulting in an $8 \mathrm{~L}$ structure with a $(c h)_{4}$ repeat pattern. Shaded spheres denote $\mathrm{Ba}$ ions. 


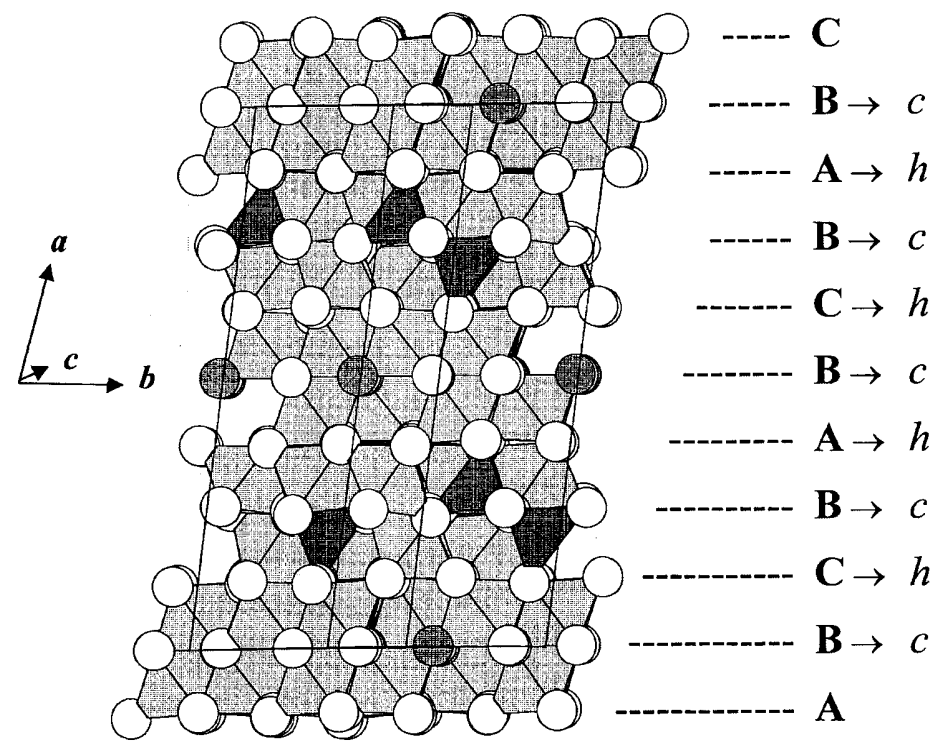

Fig. 14. The structure of $\mathrm{BaFe}_{11} \mathrm{Ti}_{3} \mathrm{O}_{23}$ as viewed approximately along the $c$-direction emphasizing the stacking sequence of the close-packed $[\mathrm{O},(\mathrm{Ba}, \mathrm{O})]$ layers [79]. The resulting $(c h) 4$ repeat pattern is the same as in $\mathrm{Ba}_{6} \mathrm{Fe}_{45} \mathrm{Ti}_{17} \mathrm{O}_{106}$. Shaded spheres denote Ba ions.

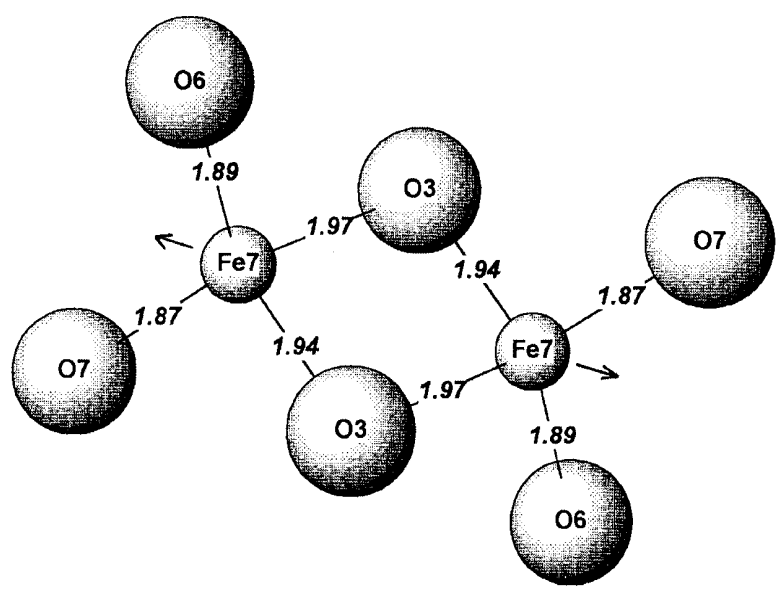

Fig. 15. Local coordination about the tetrahedral $\mathrm{Fe} 7$ sites in the $\mathrm{BaFe}_{11} \mathrm{Ti}_{3} \mathrm{O}_{23}$ structure, with bond distances indicated [79].

preferential ordering of $\mathrm{Nb}^{5+}$ at the edge of the slabs adjacent to the gap.

The $c$ parameters of seven successive members of the homologous rutile series $\mathrm{SrM}_{2 n+1} \mathrm{O}_{4 n+5}$ were found to increase from about $21 \AA$ to $47 \AA$ by approximately $4.4 \AA$ for each additional value of $n$ [84]. This increase corresponds to adding two $\mathrm{TiO}_{2}$ units to the width of the rutile slab. In this series, all phases essentially have similar dimension of $a$ and $b$. In the structure, blocks of rutile are joined together by vertex-sharing octahedra. Adjacent rutile slabs are related by a mirror plane containing the $\mathrm{Sr}$ ions, therefore it can be viewed as a "chemically twinned rutile" oxide. Figure 20 illustrates the structure of the $n=3$ member, viewed approximately along the $\langle 100\rangle$ direction. Mixed $\mathrm{Nb}$ and $\mathrm{Ti}$ were found in these octahedral sites. Similar to the two perovskite series, $\mathrm{Nb}^{5+}$ was also found to preferentially occupy the highly distorted octahedral sites at the border of the slabs.

\subsection{3 $\mathrm{AO}-\mathrm{Al}_{2} \mathrm{O}_{3}-\mathrm{Nb}_{2} \mathrm{O}_{5}(\mathrm{~A}=\mathrm{Ca}, \mathrm{Sr}$, and $\mathrm{Ba})$}

Currently $\mathrm{Ba}_{3} \mathrm{MTa}_{2} \mathrm{O}_{9}$, with $\mathrm{M}=\mathrm{Zn}$ or $\mathrm{Mg}$ are microwave materials that are used by industry for high-frequency, high-power resonator applications because of their unique dielectric properties (high permittivities (about 30), and also with low dielectric loss tangents $\left(<10^{-5}\right.$ at $\left.\left.1 \mathrm{GHz}\right)\right)$. The drawback of these materials, however, is their costly production. The ternary AO$\mathrm{Al}_{2} \mathrm{O}_{3}-\mathrm{Nb}_{2} \mathrm{O}_{5}$ systems were studied because the polarizability of $\mathrm{Ta}^{5+}$ is intermediate between $\mathrm{Al}^{3+}$ and $\mathrm{Nb}^{5+}$, and $\mathrm{Nb}_{2} \mathrm{O}_{5}$ is much less expensive then $\mathrm{Ta}_{2} \mathrm{O}_{5}$.

Figure 21 shows the phase diagram of the $\mathrm{CaO}$ $\mathrm{Al}_{2} \mathrm{O}_{3}-\mathrm{Nb}_{2} \mathrm{O}_{5}$ system [74]. Only one ternary compound was found, namely, $\mathrm{Ca}_{2} \mathrm{AlNbO}_{6}$, which is a perovskite derivative. The structure of this phase is similar to that of the othorhombic $\mathrm{CaTiO}_{3}$, except with $\mathrm{Al}^{3+}$ and $\mathrm{Nb}^{5+}$ ordered in a 1:1 manner. The slight distortion of the cell gives rise to the monoclinic space group $P 2_{1} / n$ $(a=5.3780(1) \AA, b=5.4154(1) \AA, c=7.6248(2) \AA$, and $\beta=89.968(2)^{\circ}$. A significant finding of this study pertains to the dielectric properties of compositions 


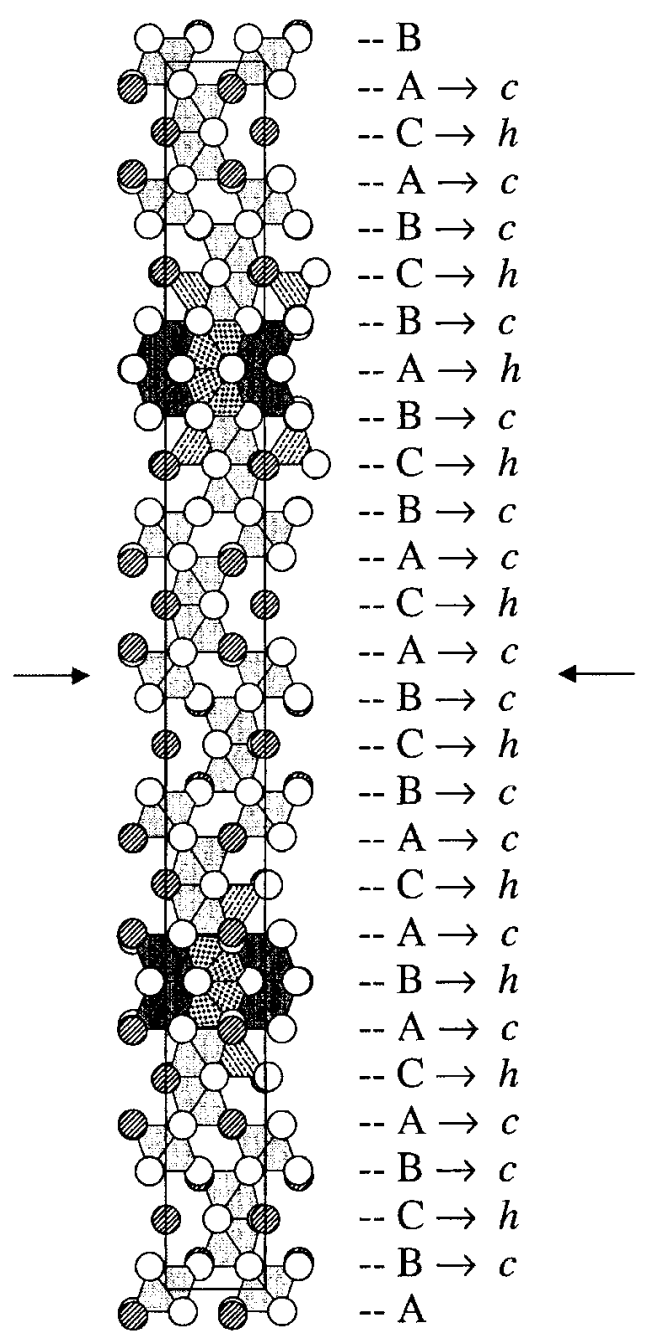

Fig. 16. The hexagonal structure of $\mathrm{Ba}_{11} \mathrm{Fe}_{8} \mathrm{Ti}_{9} \mathrm{O}_{41}$ as viewed approximately along the $\langle 110\rangle$ direction to emphasize the close-packed [O, $(\mathrm{Ba}, \mathrm{O})]$ layers [80]. The 26-layer structure of this compound exhibits the stacking sequence ( hcchchchcchc $)_{2}$. White spheres represent oxygen, striped spheres barium, and the light gray octahedra are preferrentially occupied by Ti. The darker gray and stippled octahedra occur as face-sharing pairs and are preferentially occupied by Fe. The hatched tetrahedra represent the $\mathrm{Fe} 1$ sites. Thus, the magnetic $\mathrm{Fe}$ atoms concentrate within four contiguous $c p$ layers around $z=1 / 4$ and $3 / 4$.

prepared between $\mathrm{Ca}_{3} \mathrm{Nb}_{2} \mathrm{O}_{8}$ and $\mathrm{Ca}_{2} \mathrm{AlNbO}_{6}$. These compositions have relatively high dielectric constants and high $Q$; and above all, can be tuned to having nearzero temperature coefficient. Theoretical calculations are being pursued by B. Burton and E. Cockayne to understand and predict the microwave properties of these materials.

The phase diagram of the $\mathrm{SrO}-\mathrm{Al}_{2} \mathrm{O}_{3}-\mathrm{Nb}_{2} \mathrm{O}_{5}$ system is shown in Fig. 22. In this system, in addition to the double-perovskite phase, $\mathrm{Sr}_{2} \mathrm{AlNbO}_{6}$ (Fm $3 m, \quad a=$ 7.7791(1)), two new ternary compounds, $\mathrm{Sr}_{4} \mathrm{AlNbO}_{8}$ and $\mathrm{Sr}_{5.7} \mathrm{Al}_{0.7} \mathrm{Nb}_{9.5} \mathrm{O}_{30}$ were also discovered. $\mathrm{Sr}_{5.7} \mathrm{Al}_{0.7} \mathrm{Nb}_{9.5} \mathrm{O}_{30}$ adopts the tetragonal tungsten bronze (TTB) type structure. The general formula can be written as $\mathrm{Sr}_{6-x} \mathrm{Al}_{1-x} \mathrm{Nb}_{9+x} \mathrm{O}_{30}$. A narrow stability region is observed, and the TTB structure forms only at $x=0.3$, in the high temperature range of $1375^{\circ} \mathrm{C}$ to $1425^{\circ} \mathrm{C}$. This is a solid solution with $\mathrm{Al}$ and $\mathrm{Nb}$ mixed within the octahedra. Electron diffraction results indicated that the strontium-rich $\mathrm{Sr}_{4} \mathrm{AlNbO}_{8}$ phase crystallizes with the monoclinic $P 2_{1} / c$ symmetry.

In the $\mathrm{BaO}-\mathrm{Al}_{2} \mathrm{O}_{3}-\mathrm{Nb}_{2} \mathrm{O}_{5}$ system (Fig. 23) [75], only one ternary phase was found: $\mathrm{Ba}_{5.75} \mathrm{Al}_{0.75} \mathrm{Nb}_{9.25} \mathrm{O}_{30}$ $\left(\mathrm{Ba}_{6-x} \mathrm{Al}_{1-x} \mathrm{Nb}_{9+x} \mathrm{O}_{30}, x=0.25\right)$, which crystallizes with a tetragonal tungsten bronze (TTB) type structure (P4bm; $a=12.558(1)$, and $c=3.9708(3) \AA)$. This phase exhibited an ambient dielectric constant of 242, no indication of ferroelectric behavior was observed in the temperature range $100 \mathrm{~K}$ to $400 \mathrm{~K}$. The subsystem $\mathrm{BaO}-\mathrm{Nb}_{2} \mathrm{O}_{5}$ has been studied extensively because of its complex nature. The crystal chemistry of this binary system can be largely described by octahedral units $\left[\mathrm{NbO}_{6}\right]$ except for $\mathrm{Ba}_{3} \mathrm{Nb}_{2} \mathrm{O}_{8}$, which was reported (using powder $\mathrm{x}$-ray method) to adopt the salt-like palmieritetype structure with isolated tetrahedral $\left[\mathrm{NbO}_{4}\right]$ units [85]. Single crystal structure study of this highly unstable phase in our laboratory, while confirming the tetrahedral environment of $\mathrm{Nb}$ (Fig. 24), found that all octahedral sites around $\mathrm{Nb}$ are empty [75]. This finding is contrary to the previous report of a partial $15 \%$ occupancy. All Nb metals occupy discrete tetrahedra, which is unusual and may explain its instability in the presence of water and air.

\section{Phase Equilibria and Crystallographic Studies of High-Temperature Superconductors (1986 to Present)}

Investigation of high temperature superconductor materials has been an exciting and challenging undertaking in the past fifteen years. Since 1986, a large number of multicomponent high-temperature superconductor oxide materials have been discovered; most of these compounds exhibit complex chemistry, including non-stoichiometry, defects and incommensuracy. It was recognized early on that phase equilibrium information is critical to the processing of the high $T_{\mathrm{c}}$ materials. Scientists from the Ceramics Division of NIST have since been involved with the programs of the Electric Power Research Institute (EPRI) and Department of Energy (DOE) in conducting phase equilibria research. External collaborations include Oak Ridge National Laboratory, Argonne National laboratory, Los Alamos National Laboratory, Princeton University, Florida State 


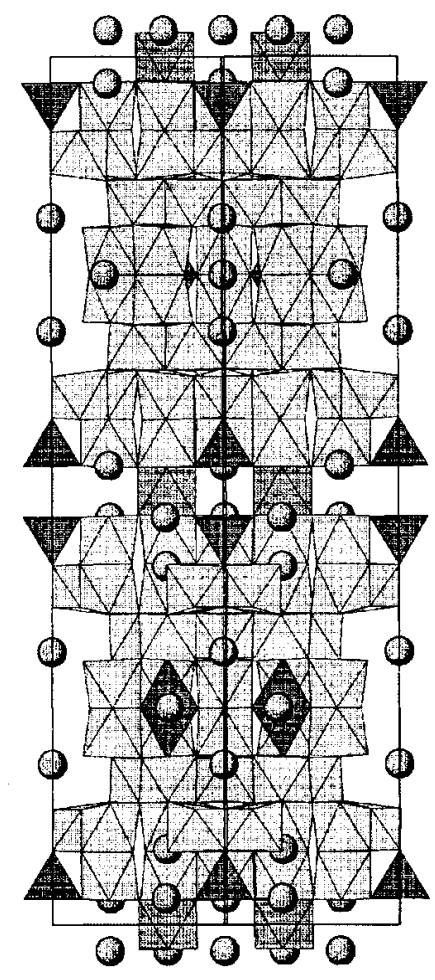

(a)

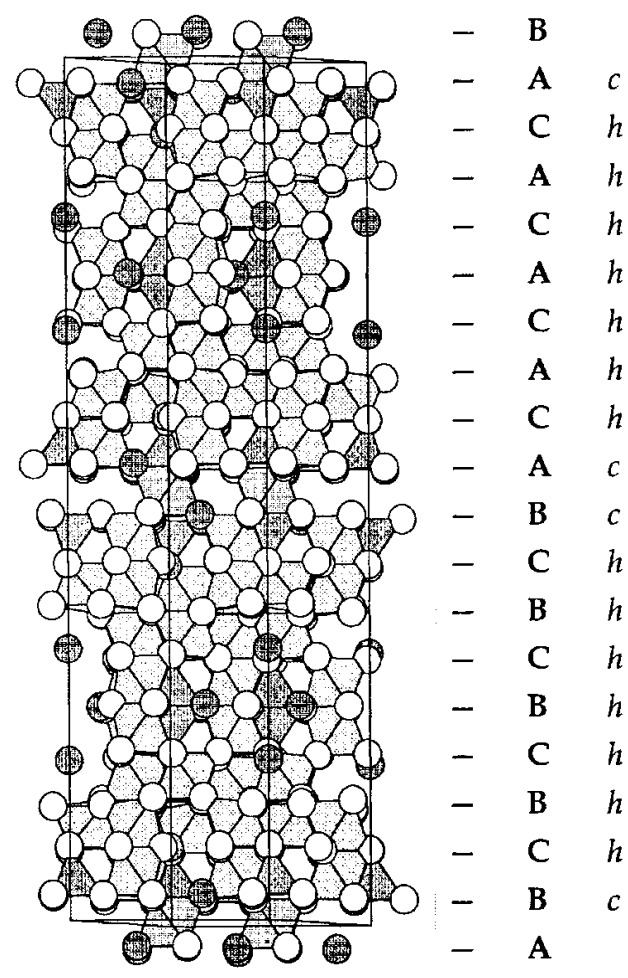

(b)

Fig. 17. Views of the $18 \mathrm{~L}$ structure of $\mathrm{Ba}_{5} \mathrm{Fe}_{4} \mathrm{Ti}_{10} \mathrm{O}_{31}$ along directions parallel to the close-packed $[\mathrm{O},(\mathrm{Ba}, \mathrm{O})]$ layers. (a) $\langle 110\rangle$ view emphasizing polyhedral arrangements, oxygen atoms are denoted by vertices, barium as spheres. (b) $\langle 100\rangle$ view with oxygens drawn as white spheres, Ba as gray, highlighting the close-packed layer sequence. The stacking pattern results in an overall $\left(\operatorname{chhhhhhhc)_{2}}\right.$ close-packed structure.

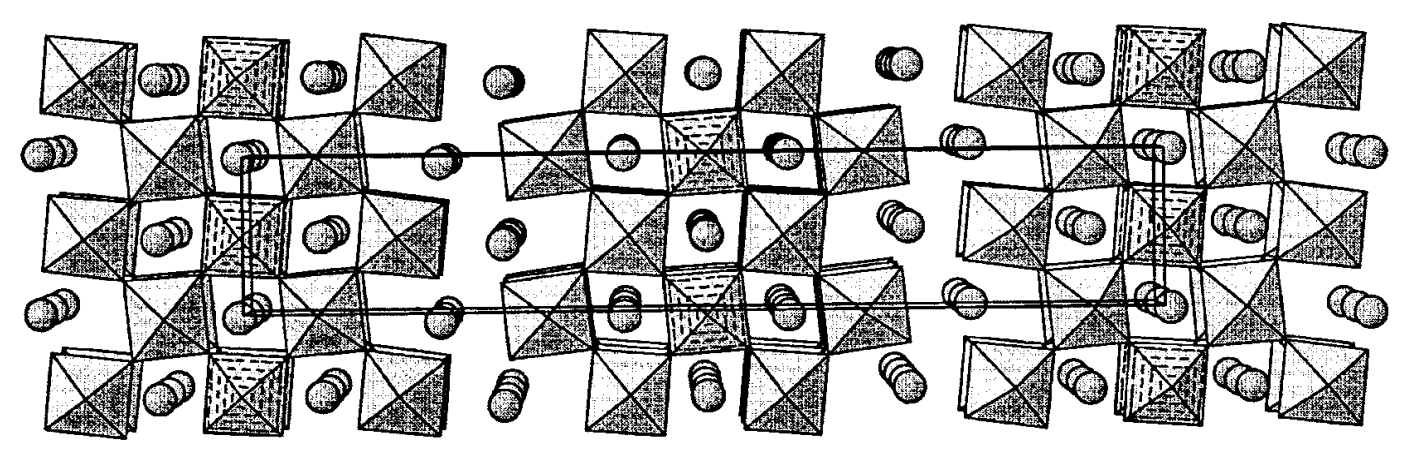

Fig. 18. Perspective view of the structure of $\mathrm{Sr}_{5} \mathrm{TiNb}_{4} \mathrm{O}_{17}$ approximately along $c$. $\mathrm{Sr}$ atoms are shown as spheres. Hatchedoctahedra are preferrentially occupied $\mathrm{Ti}$ [82]. Oxygen sites are at the vertices of the octahedra.

University, State University of New York (Buffalo), Bell Telephone Laboratory, BP-Amoco Research Center, and the Airforce Research Laboratory. Collaborators from other divisions of NIST include B. Toby, Q. Huang, A. Santoro, and J. Stalick of the Nuclear Reactor Division; C. K. Chiang of the Polymer Division; A. Kearsley of the Mathematical and Computational Sciences Division; R. Shull, L. H. Bennett, and L. Swartzendruber from Metallurgy Division; J. Suh, J. Dillingham, W. Greenwood, R. Coutts, F. Jiang and G. Thielz are student assistants from University of Maryland. 


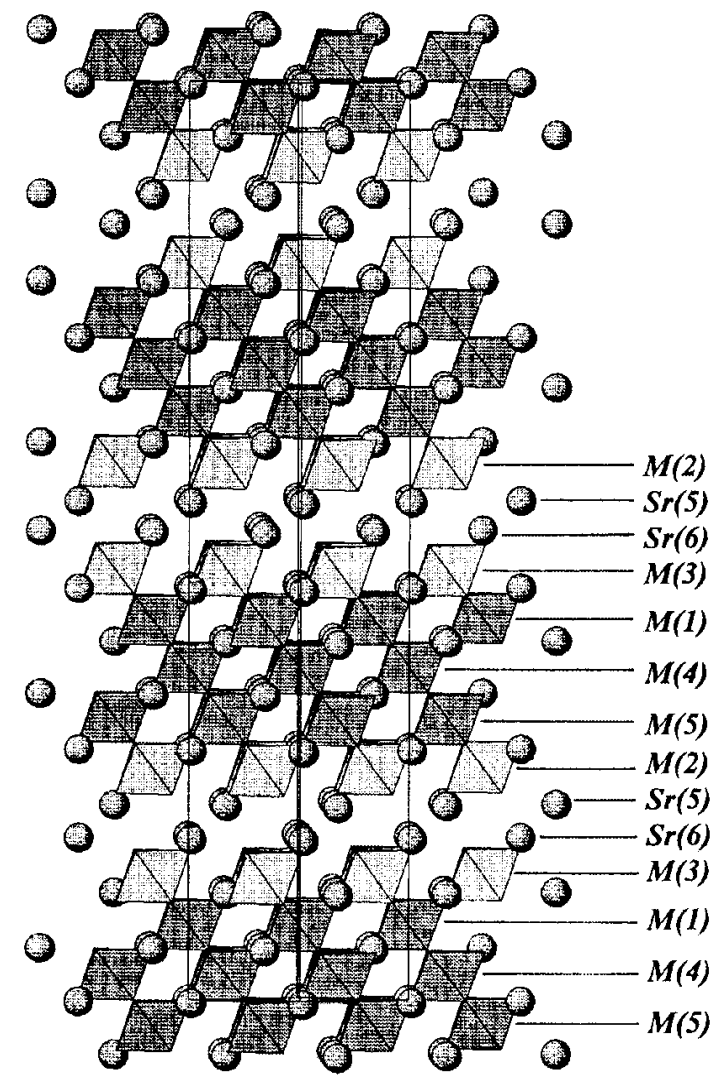

Fig. 19. Crystal structure of $\mathrm{Sr}_{6} \mathrm{TiNb}_{4} \mathrm{O}_{18}$ viewed along the $\langle 110\rangle$ direction [83]. Sr atoms are shown as spheres.

In addition to more than 150 combined journal, review articles, and proceeding papers related to phase equilibria and crystallography of high $T_{\mathrm{c}}$ related phases from the Ceramics Division, various books and book chapters have also been published. For example, T. A. Vanderah, J. D. Whitler, R. S. Roth, and H. F. McMurdie have compiled two volumes of Phase Diagrams for High $T_{\mathrm{c}}$-Superconductors [86-87]. D. L. Kaiser and L. F. Schneemeyer (Lucent Technologies) have co-authored a handbook chapter on "Single Crystal Growth" [88]. Wong-Ng has authored a handbook chapter on "Phase Diagrams" [89], and other book chapters on "Structure of Bi-containing materials" [90], and on "Superconductors: Structures and Applications" [91]. She has also co-authored with S. W. Freiman on "Superconducting Phase Formation in $\mathrm{Bi}(\mathrm{Pb})-\mathrm{Sr}-\mathrm{Ca}-$ Cu-O Glass: A Review" [92].

More than 150 reference $\mathrm{x}$-ray diffraction patterns of high $T_{\mathrm{c}}$ and related phases have been prepared at NIST and published in the ICDD Powder Diffraction File (PDF) [1]. A large portion of these patterns are results of collaborations with outside organizations such as BPAmoco Research (James A. Kaduk), North Dakota State University (Gregory J. McCarthy), and Georgia Institute of Technology (R. A. Young).

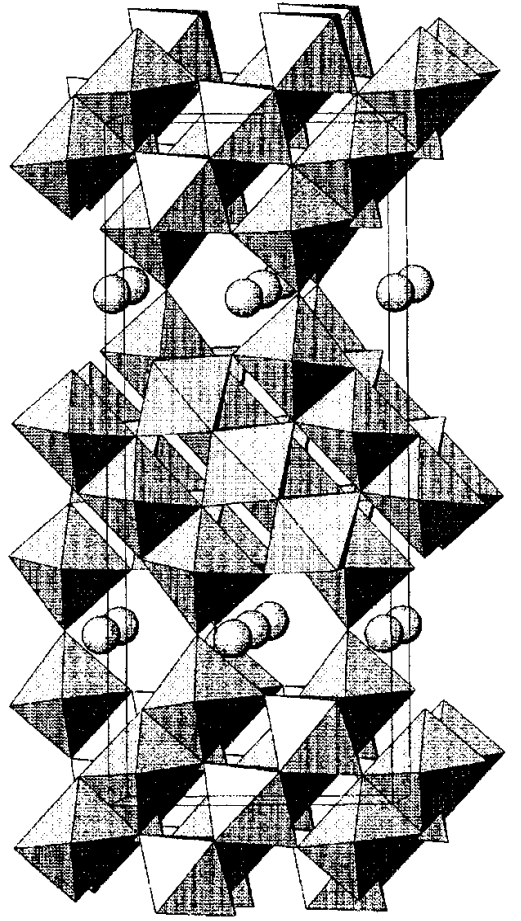

Fig. 20. The orthorhombic structure of $\mathrm{SrTi}_{3} \mathrm{Nb}_{4} \mathrm{O}_{17}$, the $n=3$ member of the "chemically twinned rutile oxides", $\mathrm{SrM}_{2 n+1} \mathrm{O}_{4 n+5}$ series, viewed approximately along the $\langle 100\rangle$ direction [84]. Spheres represent $\mathrm{Sr}^{2+}$ ions.

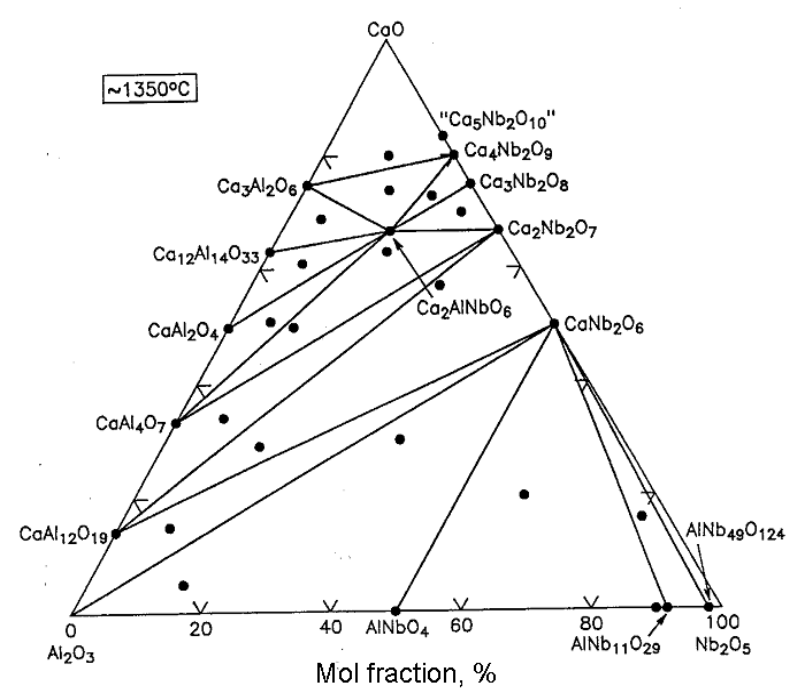

Fig. 21. Subsolidus phase equlibria relations found in the $\mathrm{CaO}: \mathrm{Al}_{2} \mathrm{O}_{3}-\mathrm{Nb}_{2} \mathrm{O}_{5}$ system in air [73]. 


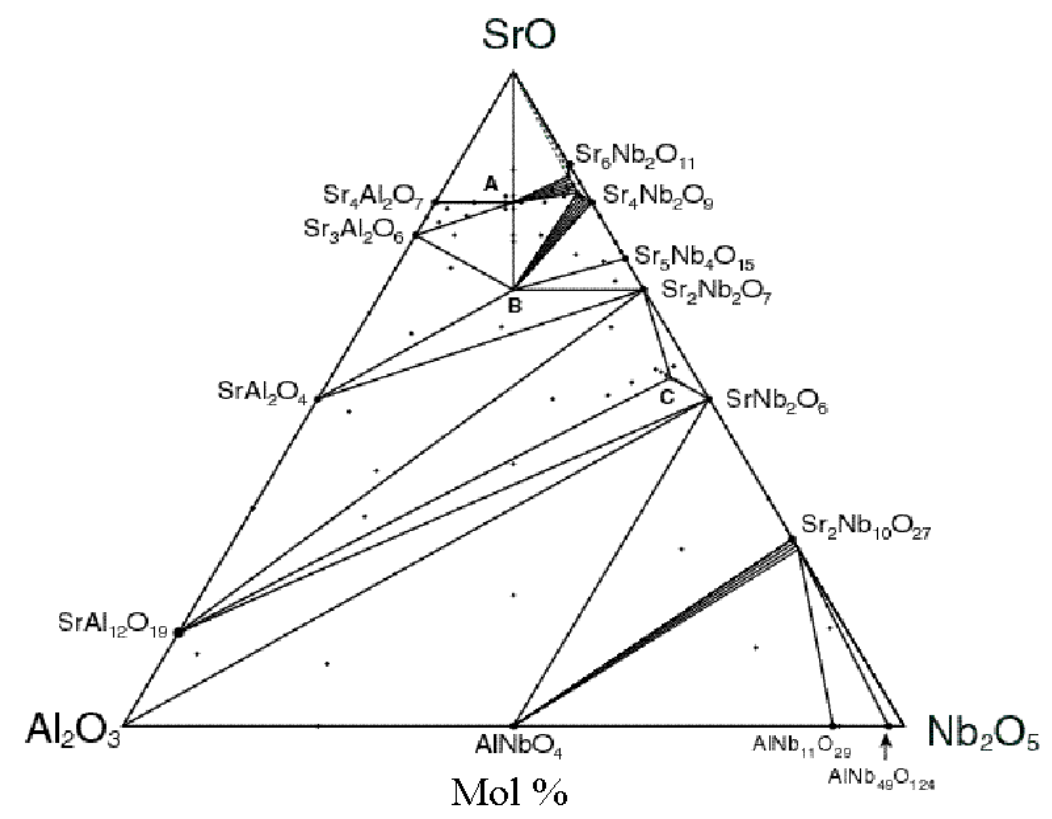

Fig. 22. Subsoldius phase equilibria relations in the $\mathrm{SrO}-\mathrm{Al}_{2} \mathrm{O}_{3}-\mathrm{Nb}_{2} \mathrm{O}_{5}$ system determined in air with synthesis temperatures $1200{ }^{\circ} \mathrm{C}$ to $1600{ }^{\circ} \mathrm{C}$ [74].

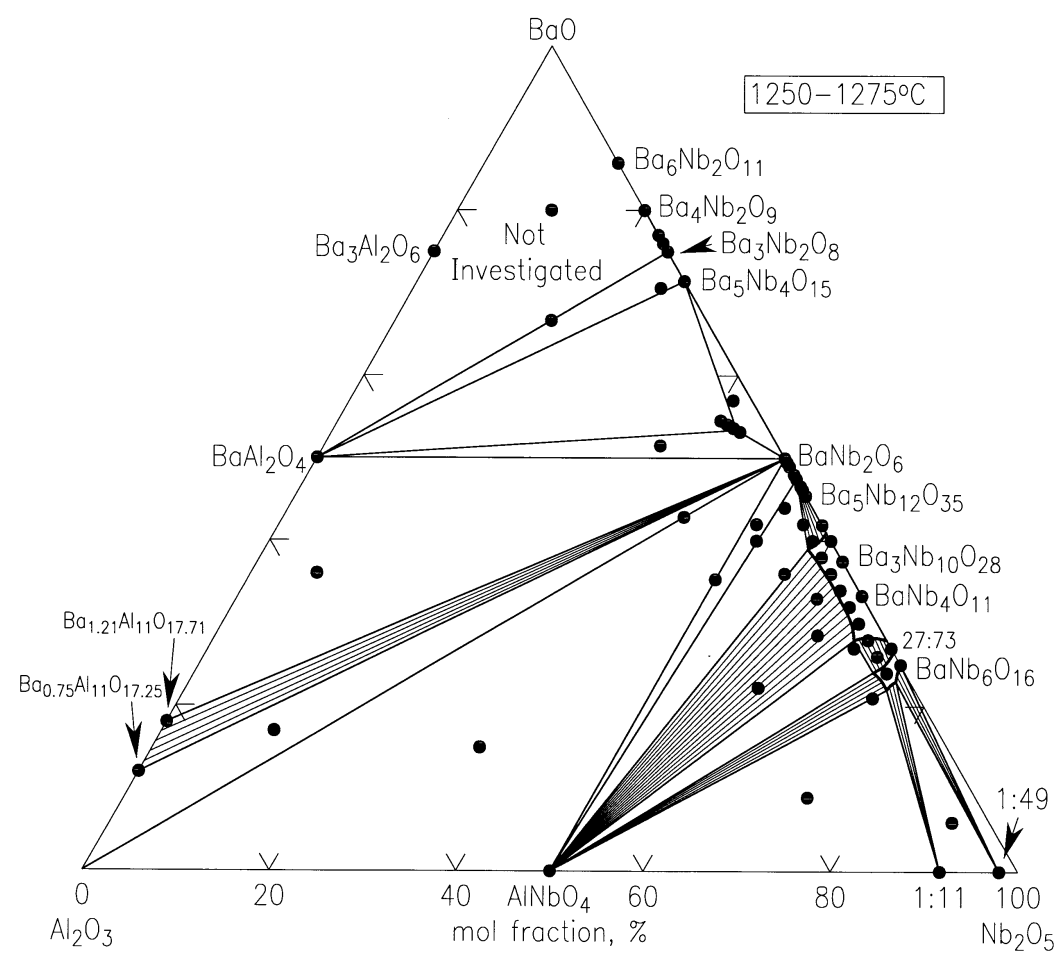

Fig. 23. Subsolidus phase equilibria relations in the $\mathrm{BaO}-\mathrm{Al}_{2} \mathrm{O}_{3}-\mathrm{Nb}_{2} \mathrm{O}_{5}$ system as determined in air. The region above the $\mathrm{BaAl}_{2} \mathrm{O}_{4}-\mathrm{Ba}_{3} \mathrm{Nb}_{2} \mathrm{O}_{8}$ tie-line was highly reactive with moisture and $\mathrm{CO}_{2}$, and was not investigated further [75]. 


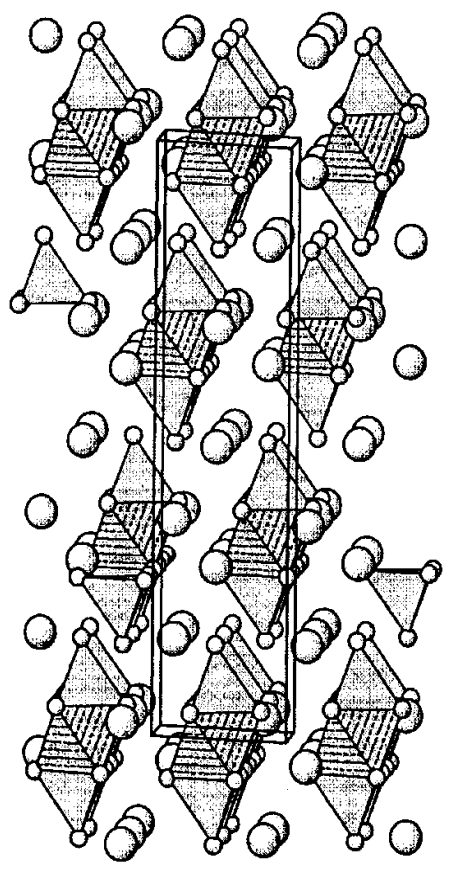

A

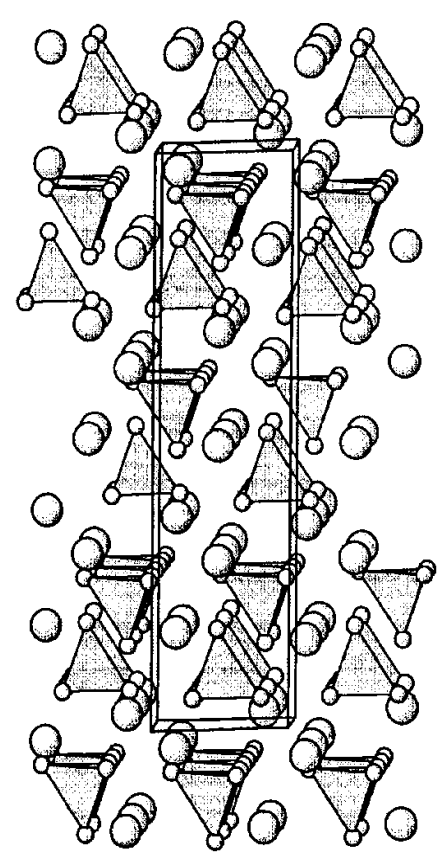

B

Fig. 24. Structures proposed for $\mathrm{Ba}_{3} \mathrm{Nb}_{2} \mathrm{O}_{8}$; (A) from analysis of $\mathrm{x}$-ray powder diffraction data [85], and (B) from single crystal study [75]. Large spheres represent Ba ions, smaller spheres are oxygens, and $\mathrm{Nb}$ ions occupy the polyhedra. The models are in agreement except that as found in (B), the $\left[\mathrm{NbO}_{6}\right]$ sites were empty and that all $\mathrm{Nb}$ ions occupy discrete tetrahedral sites.

\subsection{Ba-Y-Cu-O Systems}

\subsubsection{Subsolidus Phase Diagrams of $\mathrm{BaO}-\mathrm{Y}_{2} \mathrm{O}_{3}-\mathrm{CuO}$}

Roth et al. [93] were among the first to determine a complete phase diagram of the $\mathrm{BaO}\left(\mathrm{BaCO}_{3}\right)-\mathrm{Y}_{2} \mathrm{O}_{3}-\mathrm{CuO}$ system, at $\approx 950{ }^{\circ} \mathrm{C}$ (Fig. 25). This diagram has been used extensively as a primary reference for many years. The presence of $\mathrm{CO}_{2}$ has a substantial influence on the phase formation in the $\mathrm{Ba}$-rich region. Four phases were observed in the $\mathrm{BaO}\left(\mathrm{BaCO}_{3}\right)-2\left(\mathrm{Y}_{2} \mathrm{O}_{3}\right)$ subsystem. Barium rich $\mathrm{Ba}_{4} \mathrm{Y}_{2} \mathrm{O}_{7}$ and $\mathrm{Ba}_{2} \mathrm{Y}_{2} \mathrm{O}_{5}$ have been determined to be oxycarbonates, with formulas of $\mathrm{Ba}_{4} \mathrm{Y}_{2} \mathrm{O}_{7} \mathrm{CO}_{2}$ and $\mathrm{Ba}_{2} \mathrm{Y}_{2} \mathrm{O}_{5} 2 \mathrm{CO}_{2}$. When pure $\mathrm{BaO}$ is used instead of $\mathrm{BaCO}_{3}$, the $\mathrm{Ba}_{4} \mathrm{Y}_{2} \mathrm{O}_{7}$ and $\mathrm{Ba}_{2} \mathrm{Y}_{2} \mathrm{O}_{5}$ compounds can not be prepared in the absence of $\mathrm{CO}_{2}$ in the atmosphere. There are a total of 3 ternary oxides, including the high temperature superconductor $\mathrm{Ba}_{2} \mathrm{YCu}_{3} \mathrm{O}_{6+x},(2: 1: 3)$, and an impurity phase $\mathrm{BaY}_{2} \mathrm{CuO}_{5}(1: 2: 1)$ which is known as the "green phase". Another barium rich oxycarbonate solid solution region is known as "the other perovskite phase", and is bounded by the 4:1:2, 5:1:3 and 3:1:2 compositions. The $\mathrm{Ba}_{2} \mathrm{YCu}_{3} \mathrm{O}_{6+x}$ phase is known to exhibit an orthorhombic-tetragonal phase transition depending on the oxygen content [94].
Recently, second-generation high $T_{\mathrm{c}}$ superconductor tapes based on $\mathrm{Ba}-\mathrm{R}-\mathrm{Cu}-\mathrm{O}(\mathrm{R}=\mathrm{Y}$ and lanthanides) materials deposited on flexible coated-conductors have received considerable attentions $[95,96]$. The $\mathrm{Ba}-\mathrm{R}-\mathrm{Cu}-\mathrm{O}$ materials are relatively more isotropic when compared with $\mathrm{Bi}(\mathrm{Pb})-\mathrm{Sr}-\mathrm{Ca}-\mathrm{Cu}-\mathrm{O}$ (BSCCO)-based superconductors, and can retain current carrying ability at liquid nitrogen temperature under high magnetic fields. Because of the potential advantages of coated-conductor superconductors, a renewed research interest in the entire family of the $\mathrm{Ba}_{2} \mathrm{RCu}_{3} \mathrm{O}_{x}$ materials has been developed. Processing of $\mathrm{Ba}_{2} \mathrm{RCu}_{3} \mathrm{O}_{x}$ is typically carried out with carbonate-free precursors, phase equilibrium studies under carbonate-free and moisture-free conditions are necessary. Special apparatus and procedures for handling these atmospherically sensitive compositions have been developed. Wong-Ng and Cook [97] have successfully investigated the phase diagrams of the $\mathrm{BaO}-\mathrm{Y}_{2} \mathrm{O}_{3}$ $\mathrm{CuO}_{x}$ system at two oxygen partial pressures using carbonate-free precursors based on $\mathrm{BaO}$. Experimental results were used to establish tie-lines in the $\mathrm{BaO}$-rich part of the phase diagram (Figs. 26 and 27), and have confirmed a difference in tie-line distribution among the $\mathrm{Ba}_{2} \mathrm{YCu}_{3} \mathrm{O}_{x}, \mathrm{Ba}_{4} \mathrm{YCu}_{3} \mathrm{O}_{x}, \mathrm{BaY}_{2} \mathrm{CuO}_{5}$, and $\mathrm{BaCuO}_{2+x}$ phases under carbonate-free conditions relative to those obtained using $\mathrm{BaCO}_{3}$-derived starting materials. By 


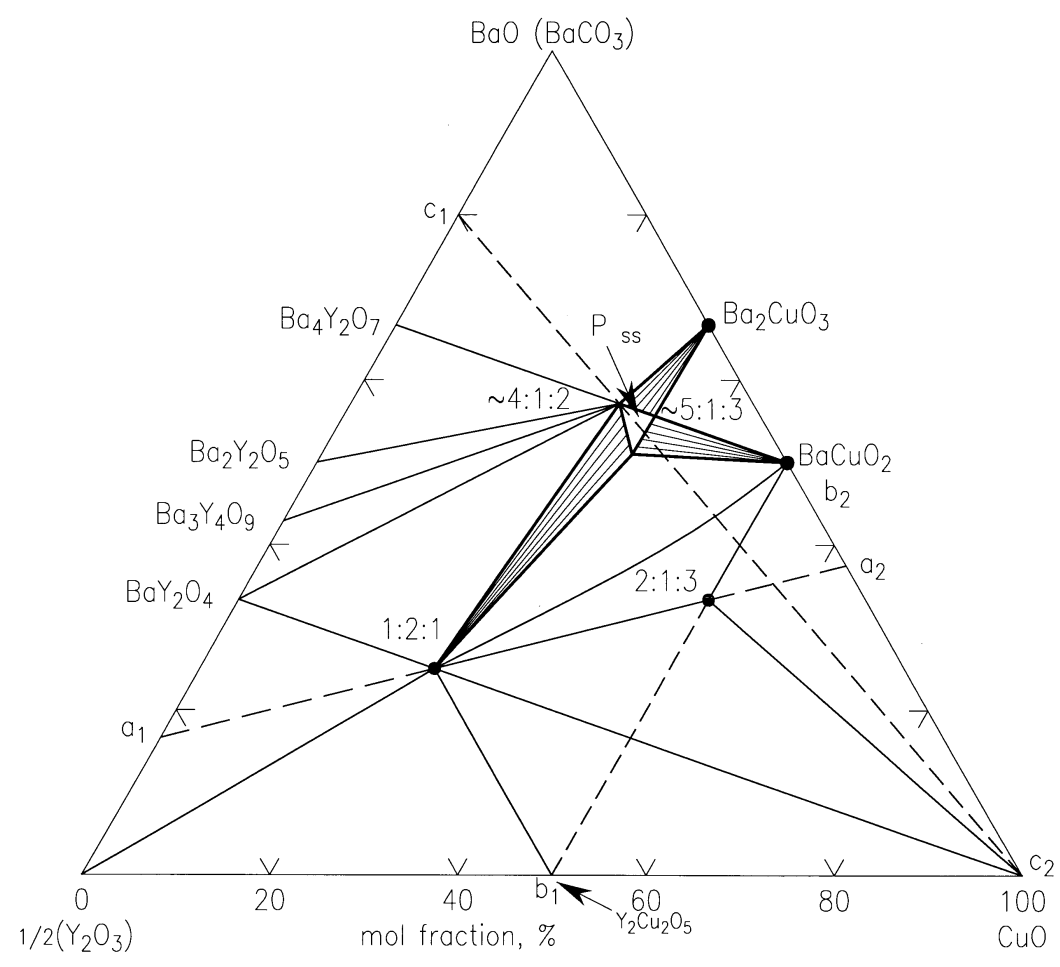

Fig. 25. Phase diagram of the ternary system $\mathrm{BaO}\left(\mathrm{BaCO}_{3}\right)-{ }^{1} / 2 \mathrm{Y}_{2} \mathrm{O}_{3}-\mathrm{CuO}$ at $\approx 950{ }^{\circ} \mathrm{C}$ [93]. The position of the $\mathrm{Ba}_{2} \mathrm{YCu}_{3} \mathrm{O}_{6+x}(2: 1: 3)$ superconductor and the green phase $\mathrm{BaY}_{2} \mathrm{CuO}_{5}$ (1:2:1) are shown.

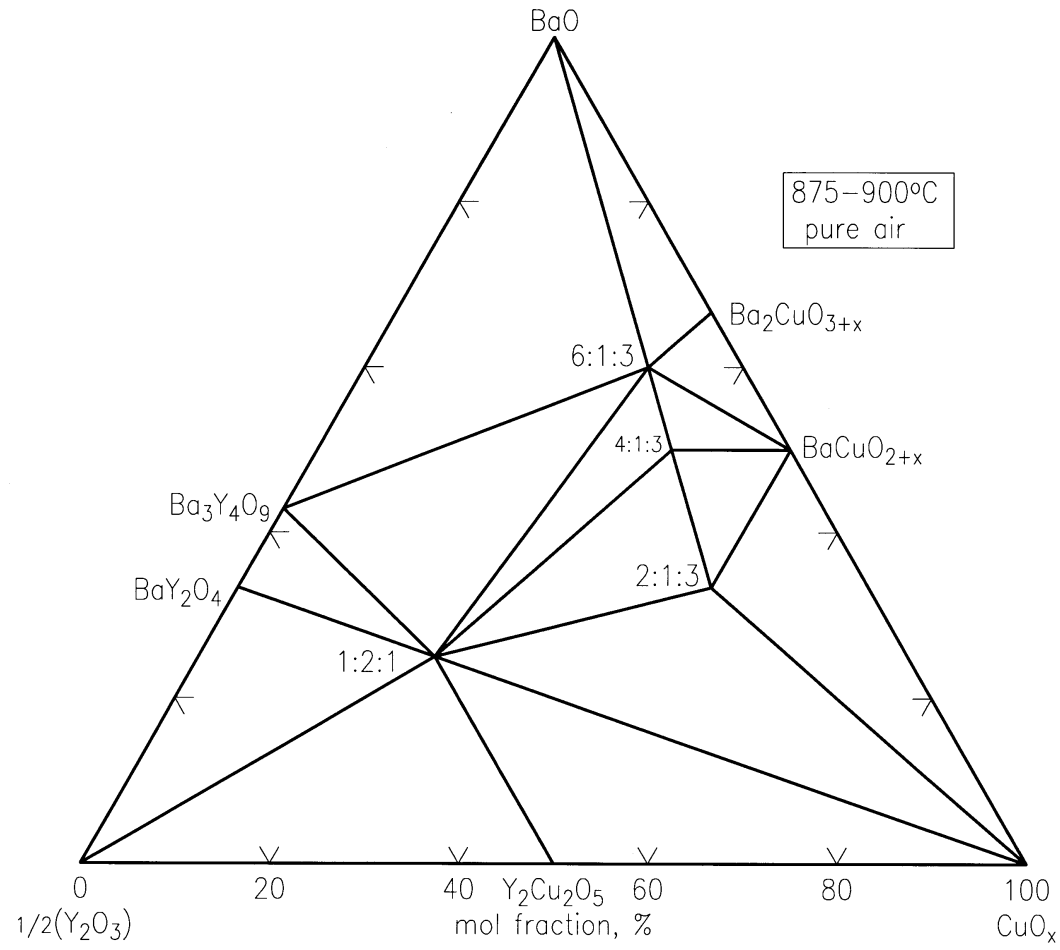

Fig. 26. Phase diagram of the $\mathrm{BaO}-{ }^{1} / 2 \mathrm{Y}_{2} \mathrm{O}_{3}-\mathrm{CuO}_{x}$ system prepared at $p_{\mathrm{O} 2}=21 \mathrm{kPa}\left(875^{\circ} \mathrm{C}\right.$ to $\left.900{ }^{\circ} \mathrm{C}\right)$. In this diagram, the symbols $(2: 1: 3),(4: 1: 3),(6: 1: 3)$, and $(1: 2: 1)$ are used to represent the phases $\mathrm{BaY}_{2} \mathrm{CuO}_{5}, \mathrm{Ba}_{4} \mathrm{YCu}_{3} \mathrm{O}_{x}, \mathrm{Ba}_{6} \mathrm{YCu}_{3} \mathrm{O}_{x}$, and $\mathrm{BaY}_{2} \mathrm{CuO}_{5}$, respectively [94]. 


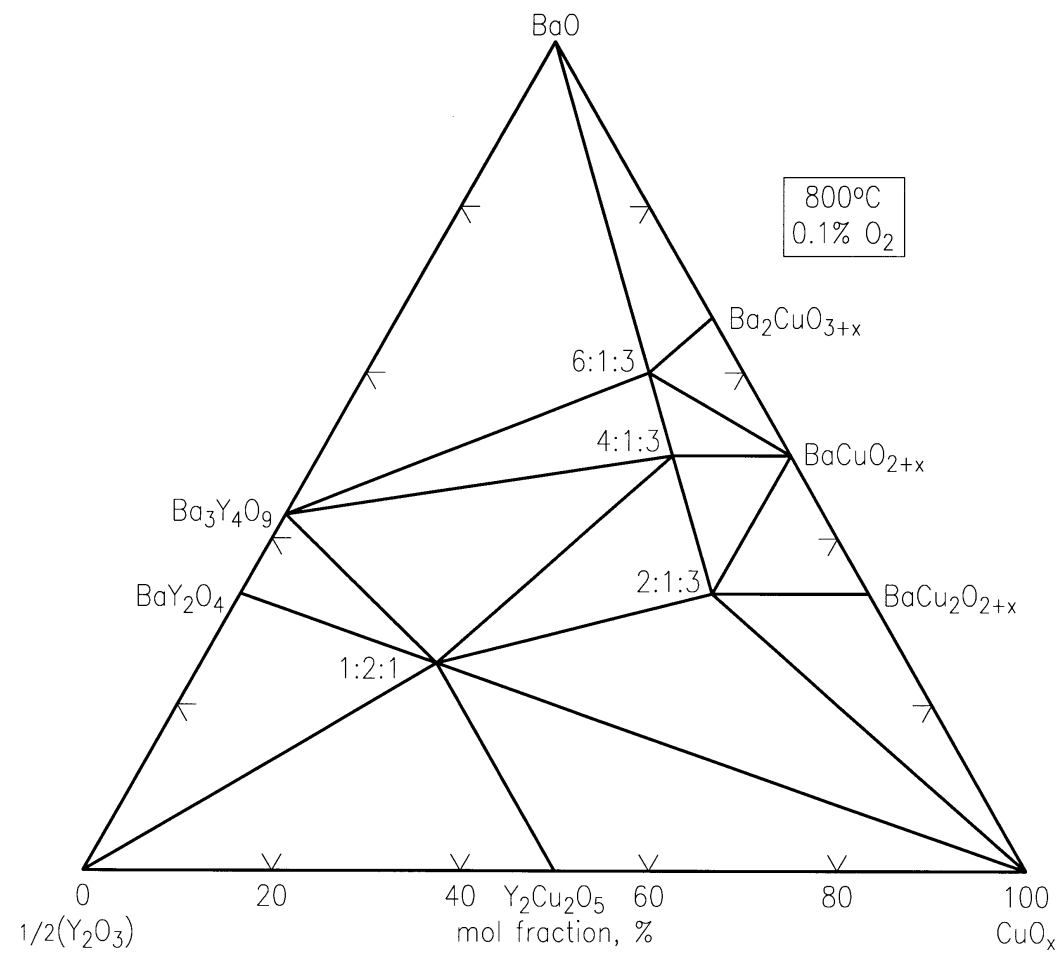

Fig. 27. Phase diagram of the $\mathrm{BaO}-{ }^{1} / 2 \mathrm{Y}_{2} \mathrm{O}_{3}-\mathrm{CuO}_{x}$ system prepared at $p_{\mathrm{O} 2}=100 \mathrm{~Pa}\left(800^{\circ} \mathrm{C}\right.$ to $\left.810^{\circ} \mathrm{C}\right)$. Symbols are shown in Fig. 2 [94].

reducing $P_{\mathrm{O} 2}$ from $21 \mathrm{kPa}$ to $100 \mathrm{~Pa}$ under carbonatefree conditions, an additional tie-line change among the phases $\mathrm{Ba}_{2} \mathrm{YCu}_{3} \mathrm{O}_{x}, \quad \mathrm{Ba}_{4} \mathrm{YCu}_{3} \mathrm{O}_{x}, \quad \mathrm{Ba}_{6} \mathrm{YCu}_{3} \mathrm{O}_{x}$ and $\mathrm{BaY}_{2} \mathrm{CuO}_{5}$ was observed.

\subsubsection{Thermomechanical Detwinning of Superconducting $\mathrm{Ba}_{2} \mathrm{YCu}_{3} \mathrm{O}_{7-x}$ Single Crystals}

$\mathrm{Ba}_{2} \mathrm{YCu}_{3} \mathrm{O}_{7-x}$ is structurally similar to ferroelastic crystals which exist in two or more states, of which a selected state is favored during the application of a mechanical stress. The transformation from one orientation to another in BYC only requires a small atomic shift and oxygen ordering. In order to obtain "true" single crystals, D. L. Kaiser and F. W. Gayle have developed an ingenious method for the complete removal of twins from $\mathrm{Ba}_{2} \mathrm{YCu}_{3} \mathrm{O}_{6+x}$ single crystals by applying a uniaxial compressive stress along an $a / b$ axis at elevated temperature [98]. Figure 28 shows the schematic diagram of the experimental apparatus used to detwin the $\mathrm{Ba}_{2} \mathrm{YCu}_{3} \mathrm{O}_{6+x}$ single crystals. Two fused-quartz slides coated with evaporated gold are held in a parallel geometry by a clamp. The spacing between the slides is established by a thickness of gold filler sheets. An aluminum crucible filled with zirconia powder was used to apply the load to the standing crystal (grown from an

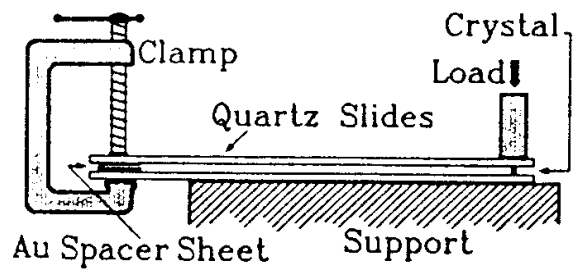

Fig. 28. Schematic diagram of the experimental apparatus used to detwin YBCO single crystals [98].

Ba-Y-Cu-O melt in a gold crucible) on the edge (with the $c$-axis in the plane of the slide). The rig was then put inside a box furnace and heated in air to $600{ }^{\circ} \mathrm{C}$ (below transformation temperature) to avoid surface roughness.

The twin-free crystals proved invaluable both for confirming or refining the crystal structure and for measuring anisotropy of physical properties along the $a$ and $b$-directions in the $\mathrm{Cu}-\mathrm{O}$ basal plane. In collaboration with S. F. Watkins and F. Fronczek of Louisiana State University [99], single crystal structure determination of a twin-free crystal was completed. Oxygen positions and occupancies in the $\mathrm{Cu}-\mathrm{O}$ basal plane have been refined, showing that while the basal plane oxygen site in the $a$-direction is completely vacant, the oxygen atoms in $b$-direction are offset from the crystallographic mirror plane positions by $0.15 \AA$ in a zig-zag fashion. A $2 \%$ mass fraction $\mathrm{Au}$ was found to occupy the chain $\mathrm{Cu}$ 
sites. Weak superlattice reflections suggest a possible 3-dimensional ordering of $\mathrm{O}$ and/or Au.

\subsubsection{Liquidus Diagrams of the Ba-Y-Cu-O System}

Melt processing investigations of $\mathrm{Ba}_{2} \mathrm{YCu}_{3} \mathrm{O}_{6+x}$ for viable commercial applications constitute a major activity within the high $T_{\mathrm{c}}$ superconductor research community. The liquidus information for the $\mathrm{Ba}-\mathrm{Y}-\mathrm{Cu}-\mathrm{O}$ system (the primary phase field for $\mathrm{Ba}_{2} \mathrm{YCu}_{3} \mathrm{O}_{6+x}$, and the univariant reactions in the phase diagram near the $\mathrm{CuO}$-rich corner) is critical for crystal growth and melt processing. Our studies provided evidence that the liquid field of the BYC phase has a miscibility gap, as shown in Fig. 29 [100]. This diagram is presented by "stretching" the customary ternary composition triangle in order to mag- nify the yttrium oxide contents of the liquids, all of which were below $4 \%$ (mole fraction). The phase fields of $\mathrm{BaY}_{2} \mathrm{O}_{4}, \mathrm{Y}_{2} \mathrm{O}_{3}, \mathrm{BaY}_{2} \mathrm{CuO}_{5}, \mathrm{Ba}_{4} \mathrm{YCu}_{3} \mathrm{O}_{x}, \mathrm{Y}_{2} \mathrm{Cu}_{2} \mathrm{O}_{5}$, $\mathrm{Cu}_{2} \mathrm{O}$, nominal $\mathrm{BaCuO}_{2}$, and $\mathrm{CuO}$ are also shown. The crystallization field of the $\mathrm{Ba}_{2} \mathrm{YCu}_{3} \mathrm{O}_{6+x}$ phase occurs in two segments. Both segments of the field are entirely below the $2.0 \mathrm{~mol}$ fraction $\% 1 / 2 \mathrm{Y}_{2} \mathrm{O}_{3}$ level. The right hand segment of the $\mathrm{Ba}_{2} \mathrm{YCu}_{3} \mathrm{O}_{6+x}$ field is bounded by the crystallization fields of $\mathrm{BaY}_{2} \mathrm{CuO}_{5}$, " $\mathrm{BaCuO}_{2}$ ", $\mathrm{Y}_{2} \mathrm{Cu}_{2} \mathrm{O}_{5}$ and $\mathrm{CuO}$, and the left hand segment was bounded by the $\mathrm{Ba}_{4} \mathrm{YCu}_{3} \mathrm{O}_{x}, \mathrm{BaY}_{2} \mathrm{CuO}_{5}$ and " $\mathrm{BaCuO}_{2}$ " primary phase fields. Two immiscible liquids were found. The determination of the $\mathrm{Ba}-\mathrm{Y}-\mathrm{Cu}-\mathrm{O}$ (213) crystallization field shows an extension into the Ba-rich region, which opens up another region for processing, and expand possible processing routes.

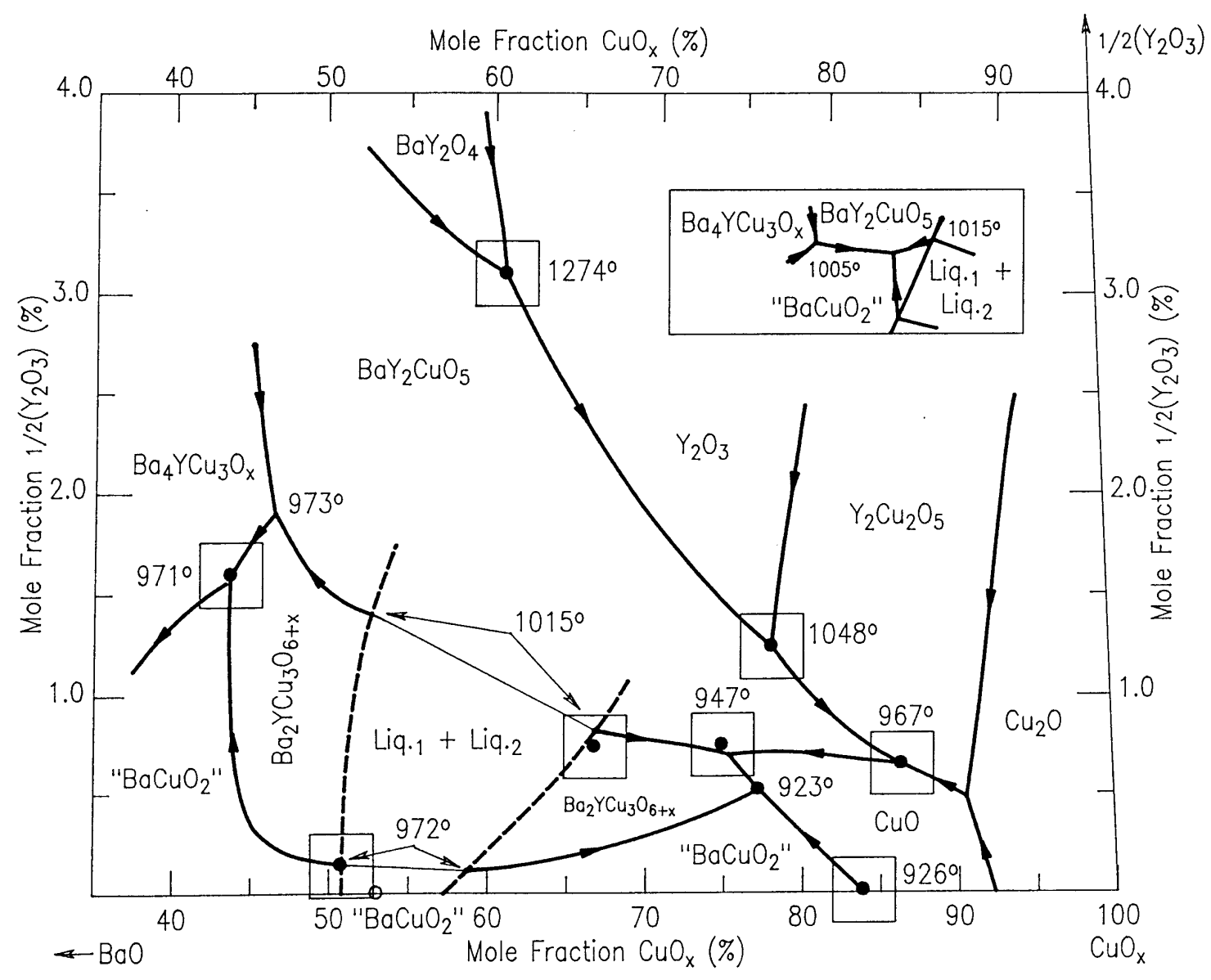

Fig. 29. The Ba-Y-Cu-O liquidus showing the primary phase fields adjacent to the $\mathrm{Ba}_{2} \mathrm{YCu}_{3} \mathrm{O}_{6+x}$ primary field, as defined by invariant (in air) melt compositions. The inset shows schematically the phase relations at the BaO-rich termination of the $\mathrm{Ba}_{2} \mathrm{YCu}_{3} \mathrm{O}_{6+x}$ field when $\mathrm{BaCO}_{3}$, rather than $\mathrm{BaO}$, was used to prepare the starting materials [100]. 


\subsection{The Barium Lanthanide Copper Oxide Systems}

\subsection{1 $\mathrm{BaO}-\mathrm{R}_{2} \mathrm{O}_{3}-\mathrm{CuO}$ Prepared Under Air}

Since the mid-eighties, an effort to understand the effect of lanthanide substitution on the properties and processing parameters of the high $T_{\mathrm{c}}$ superconductors $\mathrm{BaR}_{2} \mathrm{Cu}_{3} \mathrm{O}_{6+x}$. The progressive reduction in size of the lanthanide, which is known as the "lanthanide contraction", allows us to systematically study the trend of crystal chemistry, solid solution formation, and phase equilibria in the system $\mathrm{BaO}-\mathrm{R}_{2} \mathrm{O}_{3}-\mathrm{CuO}_{x}$ as a function of the size of lanthanide ion, $\mathrm{R}^{3+}$.
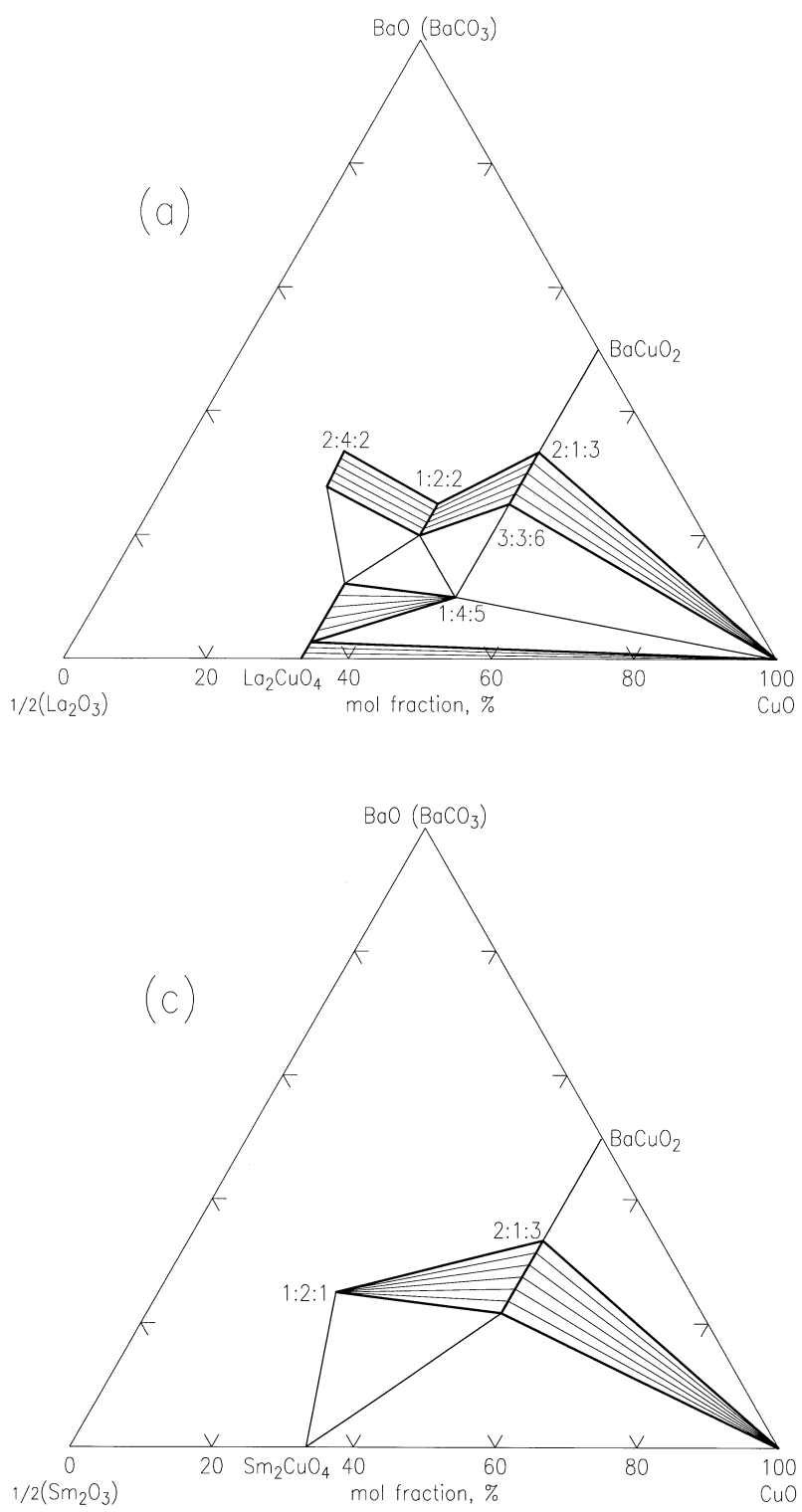

The ternary phase compatibility diagrams of the systems $\mathrm{BaO}\left(\mathrm{BaCO}_{3}\right)-1 / 2 \mathrm{Y}_{2} \mathrm{O}_{3}-\mathrm{CuO}$ and $\mathrm{BaO}\left(\mathrm{BaCO}_{3}\right)$ $1 / 2 \mathrm{R}_{2} \mathrm{O}_{3}$-CuO systems in the vicinity of the $\mathrm{CuO}$ corners, where $\mathrm{R}=\mathrm{La}, \mathrm{Nd}, \mathrm{Sm}, \mathrm{Eu}, \mathrm{Gd}, \mathrm{Er}$ are shown schematically in Fig. 30 [101]. Several features of the progressive changes in the appearance of these ternary diagrams near the $\mathrm{CuO}$ corner are: (1) the La system has the largest number of ternary compounds and solid-solution series; this number decreases as the size of $\mathrm{R}$ decreases. (2) the superconductor phase, $\mathrm{Ba}_{2} \mathrm{RCu}_{3} \mathrm{O}_{6+x}$, for the first half of the lanthanide family, i.e., $\mathrm{R}=\mathrm{La}$, $\mathrm{Nd}, \mathrm{Sm}, \mathrm{Eu}$ and $\mathrm{Gd}$, which are relatively larger in size, exhibit a solid solution of $\mathrm{Ba}_{2-z} \mathrm{R}_{1+z} \mathrm{Cu}_{3} \mathrm{O}_{6+x}$ with a range of formation which decreases as the size of $\mathrm{R}$ decreases.
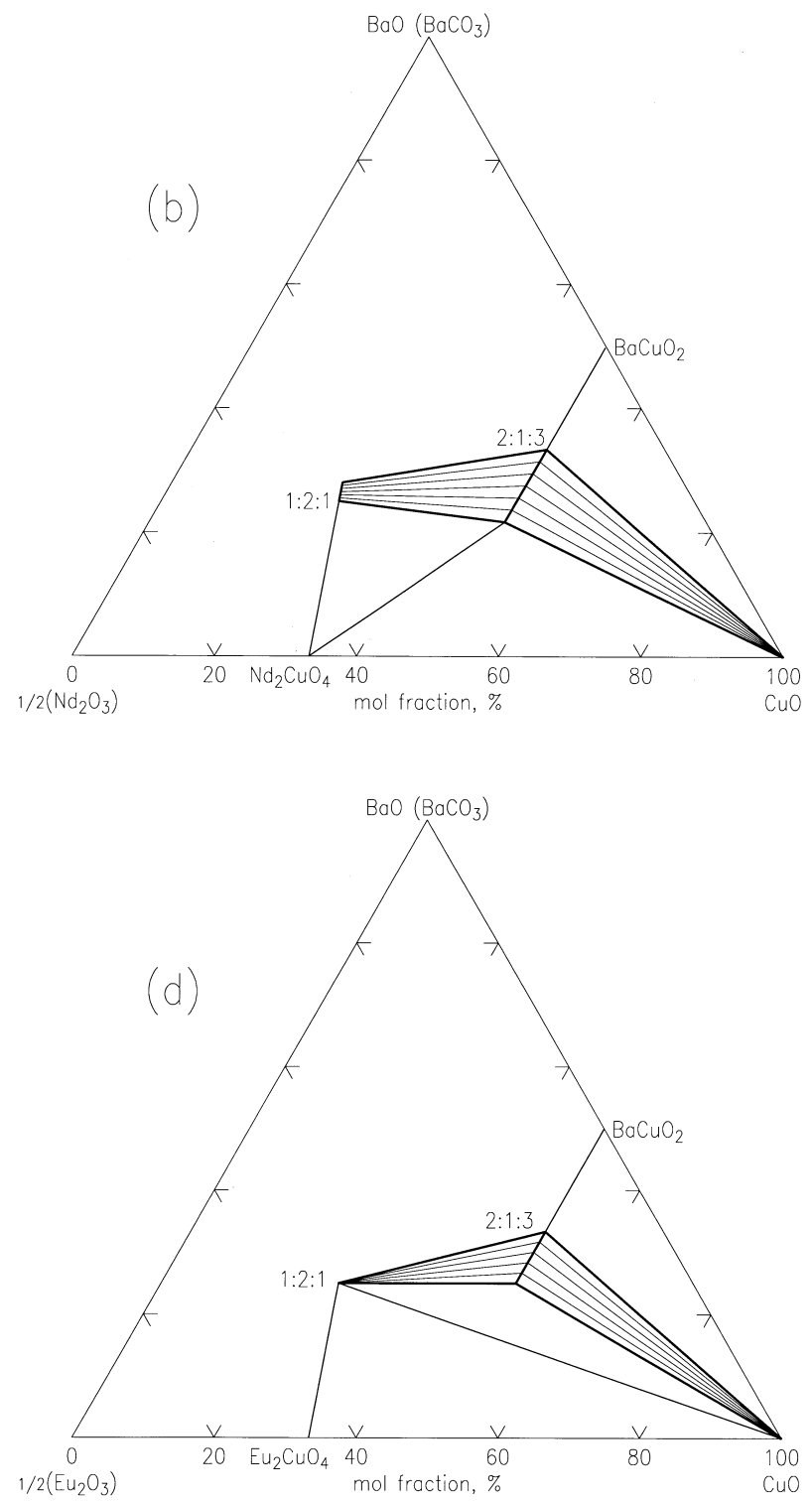

Fig. 30. Subsolidus phase compatibility diagrams of $\mathrm{BaO}-{ }^{1} / 2 \mathrm{R}_{2} \mathrm{O}_{3}-\mathrm{CuO}_{x}$ near the CuO-rich region at $950{ }^{\circ} \mathrm{C}$ in air for (a) $\mathrm{La}$, (b) $\mathrm{Nd}$, (c) $\mathrm{Sm},(\mathrm{d})$ $\mathrm{Eu},[101]$. 

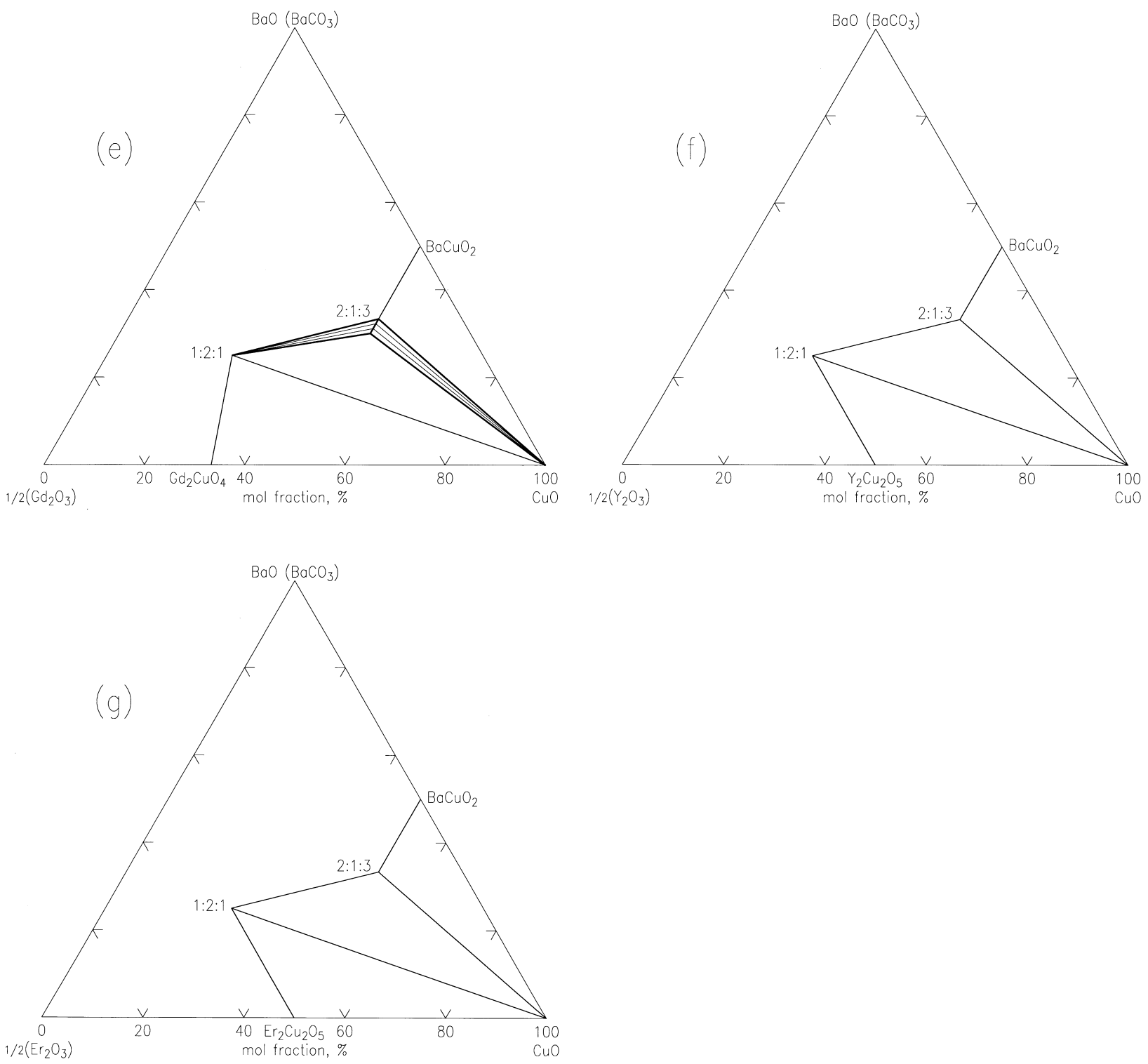

Fig. 30. (Continued) Subsolidus phase compatibility diagrams of $\mathrm{BaO}-{ }^{1} / 2 \mathrm{R}_{2} \mathrm{O}_{3}-\mathrm{CuO}$ near the CuO-rich region at $950{ }^{\circ} \mathrm{C}$ in air for (e) $\mathrm{Gd}$, (f) $\mathrm{Y}$, and $(\mathrm{g}) \operatorname{Er}[101]$.

The size compatibility between $\mathrm{Ba}^{2+}$ and $\mathrm{R}^{3+}$ is a predominant factor governing the formation of this solid solution. As the mismatch between $\mathrm{R}^{3+}$ and $\mathrm{Ba}^{2+}$ increases, the range of substitution decreases. (3) a trend is observed regarding the tie-line connections between $\mathrm{BaR}_{2} \mathrm{CuO}_{5}, \mathrm{CuO}$, the superconductor phases $\mathrm{Ba}_{2-z} \mathrm{R}_{1+z} \mathrm{Cu}_{3} \mathrm{O}_{6+x}$, and the binary phase $\mathrm{R}_{2} \mathrm{CuO}_{4}$, or $\mathrm{R}_{2} \mathrm{Cu}_{2} \mathrm{O}_{5}$; note on Fig. 30(f) that the binary phase $\mathrm{R}_{2} \mathrm{CuO}_{4}$ is replaced by the binary phase $\mathrm{R}_{2} \mathrm{Cu}_{2} \mathrm{O}_{5}$ after the tie-line connection changes.

\subsection{2 $\mathrm{BaO}-\mathrm{Nd}_{2} \mathrm{O}_{3}-\mathrm{CuO}$ Prepared Under $\mathrm{CO}_{2}$-Free Conditions}

Subsolidus phase equilibria of the $\mathrm{BaO}-\mathrm{Nd}_{2} \mathrm{O}_{3}-\mathrm{CuO}_{x}$ system at $p_{\mathrm{O} 2}=100 \mathrm{~Pa}\left(0.1 \% \mathrm{O}_{2}\right)$ and at $p_{\mathrm{O} 2}=21 \mathrm{kPa}$ $\left(21 \% \mathrm{O}_{2}\right)$ were investigated by applying controlled atmosphere methods to minimize the presence of carbonate and $\mathrm{CO}_{2}$ and $\mathrm{H}_{2} \mathrm{O}$ contamination [102]. Under carbonate-free conditions, these two diagrams are similar to one another (except for differences in the extent of the solid solutions), but substantially different from those prepared in air. The system consists of three solid solutions and one stoichiometric ternary compound. At 
$p_{\mathrm{O} 2}=21 \mathrm{kPa}$, a compositionally dependent phase change was detected in the high $T_{\mathrm{c}}$ series, $\mathrm{Ba}_{2-x} \mathrm{Nd}_{1+x} \mathrm{Cu}_{3} \mathrm{O}_{z}$, from tetragonal $(0.7>x \geq 0)$ to orthorhombic $(\approx 1.0 \geq x \geq 0.7)$. The "brown-phase" $\mathrm{Ba}_{1+x} \mathrm{Nd}_{2-x} \mathrm{CuO}_{z}$, has a narrow homogeneity region. In the high $\mathrm{BaO}$ part of the phase diagram, a solid solution $\left(\mathrm{Ba}_{2-x} \mathrm{Nd}_{x}\right) \mathrm{CuO}_{3+z}$ was confirmed. $\mathrm{Ba}_{4} \mathrm{Nd}_{2} \mathrm{Cu}_{2} \mathrm{O}_{z}$ is an insulator, with a structure comprised of unusual $\mathrm{CuO}_{5}$ linear chains. Under carbonate-free conditions, a $\mathrm{Ba}_{2-x} \mathrm{Nd}_{1+x} \mathrm{Cu}_{3} \mathrm{O}_{6+z}-(\mathrm{Ba}, \mathrm{Nd})_{2} \mathrm{CuO}_{3 \pm x}$ tie line was established, which substantially expands the field of stability of the $\mathrm{Ba}_{2-x} \mathrm{Nd}_{1+x} \mathrm{Cu}_{3} \mathrm{O}_{6+z}$ superconductor phase into the $\mathrm{BaO}-$ rich region of the phase diagram.

\subsubsection{Orthorhombic to Tetragonal Phase Transformation of $\mathrm{Ba}_{2} \mathrm{RCu}_{3} \mathrm{O}_{6+x}$}

It is well known that the 213-type phase undergoes phase transition as a function of oxygen content. Oxygen stoichiometry is important in determining the properties of superconductors. The phase transformation between the orthorhombic and tetragonal structures of six high $T_{\mathrm{c}}$ superconductors, $\mathrm{Ba}_{2} \mathrm{RCu}_{3} \mathrm{O}_{6+x}$, where $\mathrm{R}=\mathrm{Sm}$, $\mathrm{Gd}, \mathrm{Y}, \mathrm{Ho}, \mathrm{Er}$ and $\mathrm{Nd}$, and $x=0$ to 1 , have been determined $[103,104]$. The transformation from the oxygenrich orthorhombic phase to the oxygen-deficient tetragonal phase involves two orthorhombic phases. The structural phase transition temperatures, oxygen stoichiometry and characteristics of the $T_{\mathrm{c}}$ plateaus appear to follow a trend anticipated from the dependence of the ionic radius on the number of $f$ electrons as $\mathrm{R}$ progresses across the lanthanide series. Lanthanide elements with a smaller ionic radius stabilize the orthorhombic phase to higher temperatures and lower oxygen content. Also, the superconducting temperature is less sensitive to the oxygen content for materials with smaller ionic radius. A superlattice cell caused by oxygen ordering, with $a^{\prime}=2 a$, was observed for materials with smaller ionic radius.

\subsection{Sr-R-Cu-O Systems}

Since $\mathrm{Ba}$ and $\mathrm{Sr}$ are both alkaline-earth elements, studies of phase equilibria of the Sr-substituted systems may provide further understanding of the crystal chemistry of these lanthanide cuprates. While the Sr-213 phase $\mathrm{Sr}_{2} \mathrm{RCu}_{3} \mathrm{O}_{6+x}$ is not stable in the $\mathrm{Sr}$-system under ambient conditions, it can be stabilized either under high pressure [105], or when $\mathrm{Cu}$ at the basal chain site is partially or completely replaced by appropriate metals [106]. The phase formation, crystallography and crystal chemistry of the $\mathrm{Sr}_{2} \mathrm{R}(\mathrm{Cu}, \mathrm{M})_{3} \mathrm{O}_{6+x}$ (2112) structure $(\mathrm{M}=\mathrm{Al}, \mathrm{Ga}, \mathrm{Ta}$, and $\mathrm{Nb}$, and $\mathrm{R}=\mathrm{La}, \mathrm{Pr}, \mathrm{Nd}, \mathrm{Sm}, \mathrm{Eu}$, $\mathrm{Gd}$, Dy, Ho, Er, Tm, Yb, and Lu) have been systematically studied at NIST $[107,108]$.
The phase diagrams of the $\mathrm{SrO}-\mathrm{R}_{2} \mathrm{O}_{3}-\mathrm{CuO}_{x}$ systems [108], where $\mathrm{R}=\mathrm{La}, \mathrm{Nd}$, Dy, $\mathrm{Y}, \mathrm{Ho}$ and $\mathrm{Yb}$ are shown in Fig. 31. A trend similar to that identified in the Ba-containing systems can be observed: the number of phases formed correlates with the size of R-ions. Larger lanthanide ions result in more complicated phase diagrams with a greater number of ternary phases.

In these systems, the structure of two related phases, $\mathrm{Sr}_{2-x} \mathrm{R}_{1+x} \mathrm{Cu}_{2} \mathrm{O}_{z} \quad$ (212) and $\mathrm{Sr}_{1+x} \mathrm{R}_{2-x} \mathrm{Cu}_{2} \mathrm{O}_{z} \quad$ (122) $(\mathrm{R}=\mathrm{Nd}$ and $\mathrm{Dy})$, are of particular interest because of the presence of layers of double-copper oxide pyramids [Fig. 32(b) and 32(c)]. The cation positions in these compounds are the same, only the oxygen distributions are different, and the lattice parameter $b$ was found to be $b_{212} \approx 3 b_{122}$. The structure of the tetragonal 122 phase $(\mathrm{I} 4 / \mathrm{mmm}, a=3.838401 \AA$ and $c=19.647692 \AA$ for $\mathrm{SrNd}_{2} \mathrm{Cu}_{2} \mathrm{O}_{z}$ ) is derived from $\mathrm{Sr}_{3} \mathrm{Ti}_{2} \mathrm{O}_{7}$ [Fig. 32(a)], which consists of a single rock salt layer alternating with two perovskite layers. Oxygen vacancies are found in the 122 perovskite unit, leading to square-pyramid copper coordinations and extended $\mathrm{CuO}$ planes. The structure of the orthorhombic (Immm) Nd- and Dy-212 analog is shown in Fig. 32(c). The perovskite slab [highlighted in Fig. 32(c)] features a structure motif of the 213 superconductor. While in 213 all $\mathrm{Cu}-\mathrm{O}$ layers are infinite, the $\mathrm{Cu}-\mathrm{O}$ units in the 212 structure are continuous only in the $b$-direction.

\subsection{Bi-Pb-Sr-Ca-Cu-O System}

Superconducting bismuth cuprates, which exhibit variations of cation ratio, form a family of layered-structure phases with ideal formulas $\mathrm{Bi}_{2} \mathrm{Sr}_{2} \mathrm{Ca}_{n-1} \mathrm{Cu}_{n} \mathrm{O}_{4+2 n}$ ( $n=1,2$, and 3) (BSCCO). Three well known superconductor phases in the BSCCO system are commonly referred to (in the order of $\mathrm{Bi}: \mathrm{Sr}: \mathrm{Ca}: \mathrm{Cu}$ ) as the 1-layered

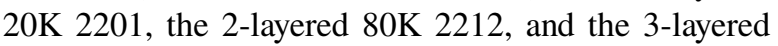
$110 \mathrm{~K} 2223$ phase. Among them, the two most widely investigated ones are the 2212 [109] and the $\mathrm{Pb}$-doped $2223((\mathrm{Bi}, \mathrm{Pb}): \mathrm{Sr}: \mathrm{Ca}: \mathrm{Cu})$ phase [110-111]. These superconductors showed promising superconducting and other properties which are appropriate for wire and tape applications.

Bismuth forms peculiar and complicated structures partly due to the presence of the inert lone pair electrons. Chemical bonding in complexes with inert pair $s^{2}$ ions is largely determined by $s-p$ mixing [112]. $\mathrm{In}^{3 i^{3+}}$, $6 s-6 p$ hybridization results in a pair of electrons being pushed off to one side of $\mathrm{Bi}$ so that the strong bonds are on the opposite side. These lone pair electrons affect the stereochemistry and become one of the common features of the Bi-containing compounds in the BSCCO system. In many compounds these lone pairs occupy channels in the structure. $\mathrm{Bi}$ is in general found to coordinate to from three to six oxygen atoms. 


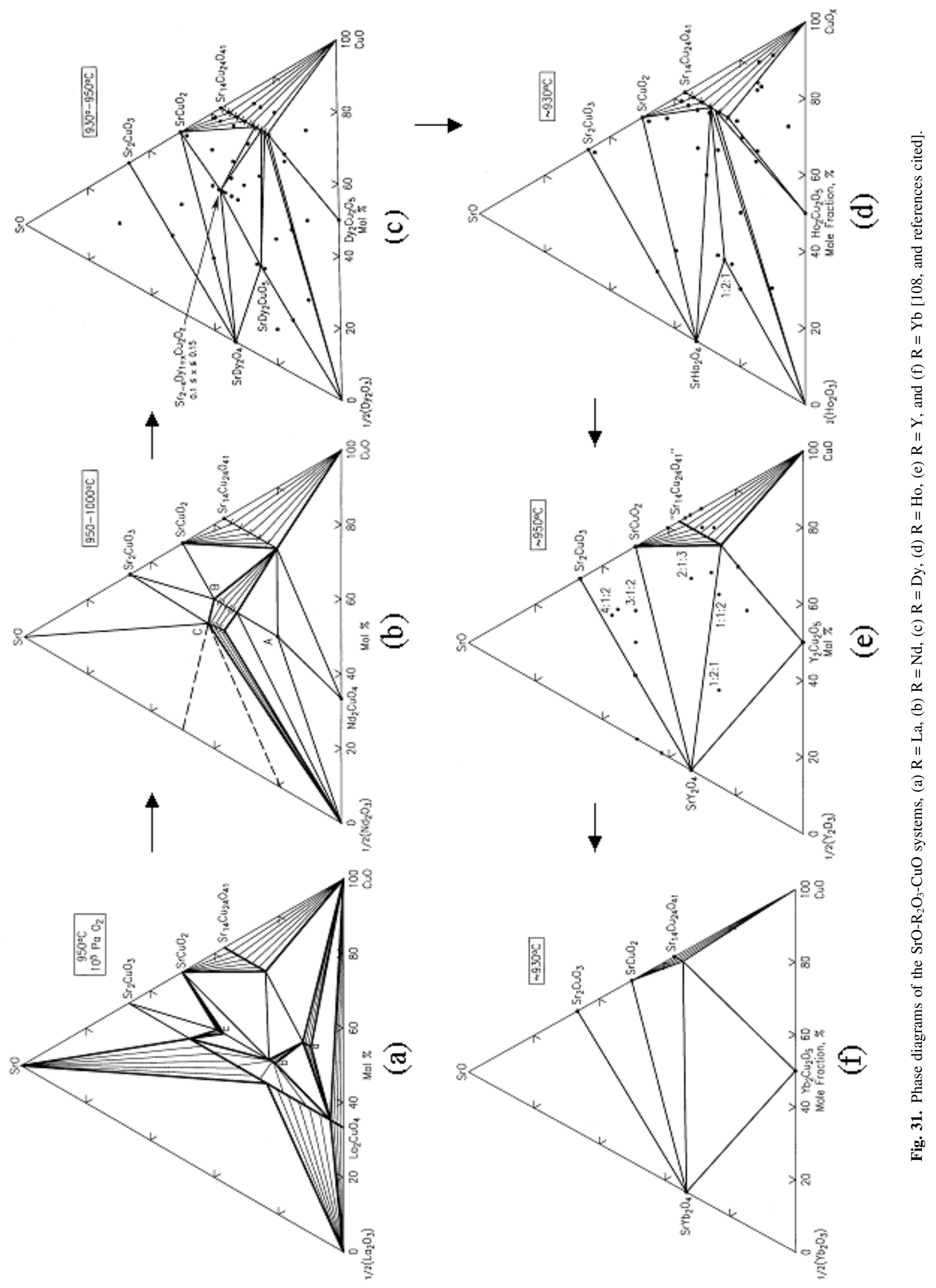




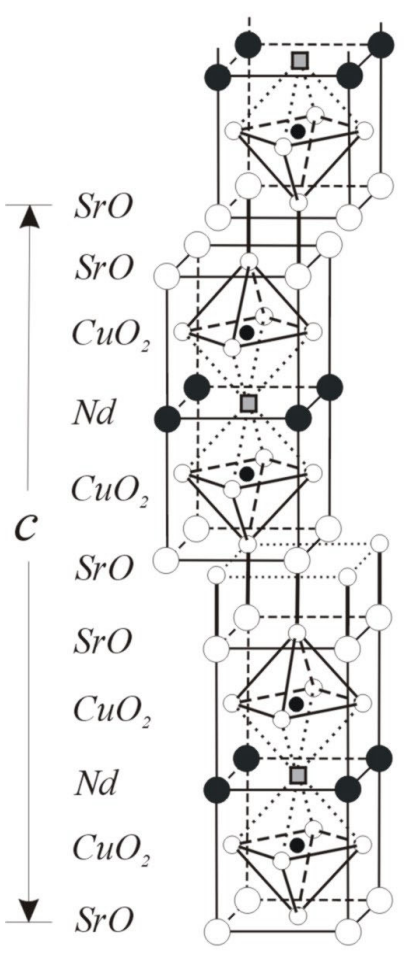

(a)

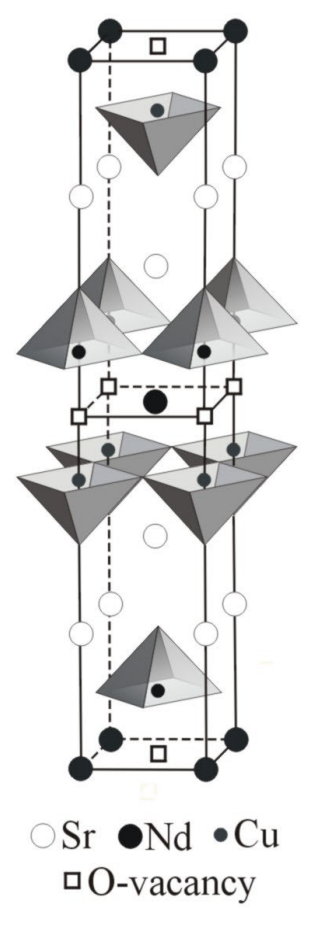

(b)

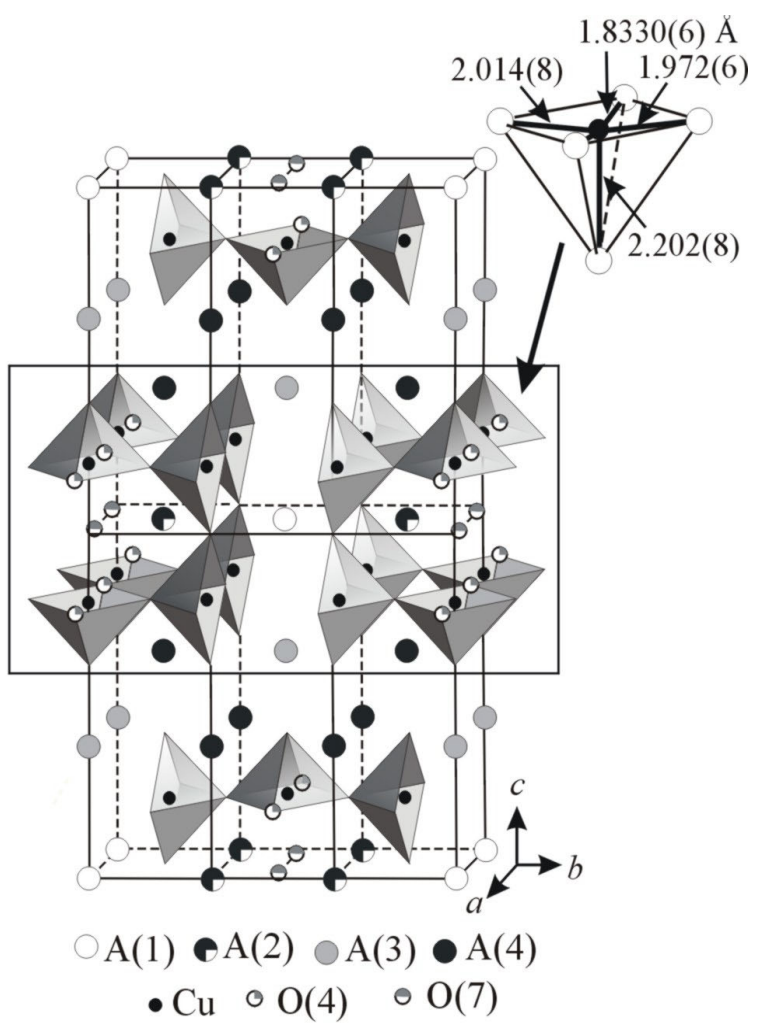

(c)

Fig. 32. Structure of (a) $\mathrm{Sr}_{3} \mathrm{Ti}_{2} \mathrm{O}_{7}$ (b) $\mathrm{Sr}_{1+x} \mathrm{R}_{2-x} \mathrm{Cu}_{2} \mathrm{O}_{z}$ (122) and $\mathrm{Sr}_{2-x} \mathrm{R}_{1+x} \mathrm{Cu}_{2} \mathrm{O}_{x}$ (212) phase [108]. Cations in sites 1 and 3 are mainly occupied by the lanthanides, while site 2 is predominantly occupied by $\mathrm{Sr}$.

\subsubsection{Subsolidus Ternary Diagrams}

Roth and co-workers completed the various binary and ternary diagrams: $\mathrm{SrO}-\mathrm{CuO}, \mathrm{SrO}-\mathrm{Bi}_{2} \mathrm{O}_{3}, \mathrm{SrO}-$ $\mathrm{Bi}_{2} \mathrm{O}_{3}-\mathrm{CuO}, \mathrm{CaO}-\mathrm{Bi}_{2} \mathrm{O}_{3}-\mathrm{CuO}$, SrO-CaO- $\mathrm{Bi}_{2} \mathrm{O}_{3}$, SrO$\mathrm{Bi}_{2} \mathrm{O}_{3}-\mathrm{CuO}, \mathrm{CaO}-\mathrm{CuO}, \mathrm{CaO}-\mathrm{Bi}_{2} \mathrm{O}_{3}, \mathrm{CaO}-\mathrm{Bi}_{2} \mathrm{O}_{3}-\mathrm{CuO}$, $\mathrm{SrO}-\mathrm{CaO}-\mathrm{Bi}_{2} \mathrm{O}_{3}$. Examples of new phases whose structures have been determined are $\mathrm{Ca}_{1-x} \mathrm{CuO}_{2}, \mathrm{Sr}_{14} \mathrm{Cu}_{24} \mathrm{O}_{41}$, $\left(\mathrm{Sr}_{0.16} \mathrm{Ca}_{0.84}\right) \mathrm{CuO}_{2}, \quad \mathrm{Ca}_{4} \mathrm{Bi}_{6} \mathrm{O}_{13}, \quad \mathrm{Sr}_{2} \mathrm{Bi}_{2} \mathrm{O}_{5}, \quad \mathrm{Ca}_{6} \mathrm{Bi}_{6} \mathrm{O}_{15}$, $\mathrm{CaBi}_{2} \mathrm{O}_{4}, \mathrm{Sr}_{2} \mathrm{Bi}_{2} \mathrm{CuO}_{6}, \mathrm{SrBi}_{2} \mathrm{O}_{4}, \mathrm{Bi}_{14}(\mathrm{Sr}, \mathrm{Ca})_{12} \mathrm{O}_{x}$, and $\mathrm{Bi}_{2}(\mathrm{Sr}, \mathrm{Ca})_{4} \mathrm{O}_{x}$.

\subsubsection{SrO-CaO-CuO}

In this system, mole fraction compositions with less than $33.3 \% \mathrm{CuO}$ were not investigated [113]. Three solid solutions were determined: $\mathrm{Sr}_{2-x} \mathrm{Ca}_{x} \mathrm{CuO}_{3}$, $\mathrm{Sr}_{1-x} \mathrm{Ca}_{x} \mathrm{CuO}_{2}$ and $\mathrm{Sr}_{14-x} \mathrm{Ca}_{x} \mathrm{Cu}_{24} \mathrm{O}_{41}$. A new ternary phase $\left(\mathrm{Sr}_{x} \mathrm{Ca}_{1-x}\right) \mathrm{CuO}_{2} \quad(x \approx 0.15)$ was determined [114]. This phase has an interesting structure (Fig. 33) because it can be regarded as the parent structure of $\mathrm{A}_{2} \mathrm{~B}_{2} \mathrm{Ca}_{n-1} \mathrm{Cu}_{n} \mathrm{O}_{4+2 n}$ for very large $n$, where $\mathrm{A}=\mathrm{Bi}, \mathrm{Tl}$; $\mathrm{B}=\mathrm{Ba}$, Sr. $\left.\mathrm{Ca}_{0.86} \mathrm{Sr}_{0.14}\right) \mathrm{CuO}_{2}$ was found to be tetragonal with space group $P 4 / \mathrm{mmm}$, and $a=3.8611(2) \AA$, and $c=3.1995(2) \AA$ A. This simple perovskite with a regular coordination for $\mathrm{Ca}, \mathrm{Sr}$ and $\mathrm{Cu}$ is built from square-planar $\mathrm{CuO}_{2}$ sheets that sandwich $\mathrm{Ca}$ and $\mathrm{Sr}$ ions. The high symmetry and small unit cell can be considered as a result of deleting the bismuth oxide layers from the superconductor structure.

\subsubsection{2 $\mathrm{SrO}_{-}-\mathrm{Bi}_{2} \mathrm{O}_{3}-\mathrm{CuO}$}

Four ternary oxide compounds were found (Fig. 34) [115]. Note the co-existence of the solid solution $\mathrm{Bi}_{2.2-x} \mathrm{Sr}_{1.8+x} \mathrm{CuO}_{z}$ (commonly referred to as the Raveau 11905 phase) and the $\mathrm{Bi}_{2} \mathrm{Sr}_{2} \mathrm{CuO}_{6}(2201)$ phase. It is this 11905 phase that is the 1-layered $9 \mathrm{~K}$ to $20 \mathrm{~K}$ superconductor. The Raveau phase and the 2201 phase are in equilibrium with each other. The Raveau solid solution was found to extend from approximately $0.0<x \leq 0.15$ for $\mathrm{Sr}_{1.8-x} \mathrm{Bi}_{2.2+x} \mathrm{Cu}_{1 \pm x / 2} \mathrm{O}_{z}$, and is structurally similar to the $n=1$ member of $\mathrm{Sr}_{2} \mathrm{Bi}_{2} \mathrm{Ca}_{n-1} \mathrm{Cu}_{n} \mathrm{O}_{2 n+4}$. Throughout the literature, the 2201 symbol is commonly used in place of the Raveau phase, and may be interpreted as a part of the extended single phase region of the Raveau phase. 

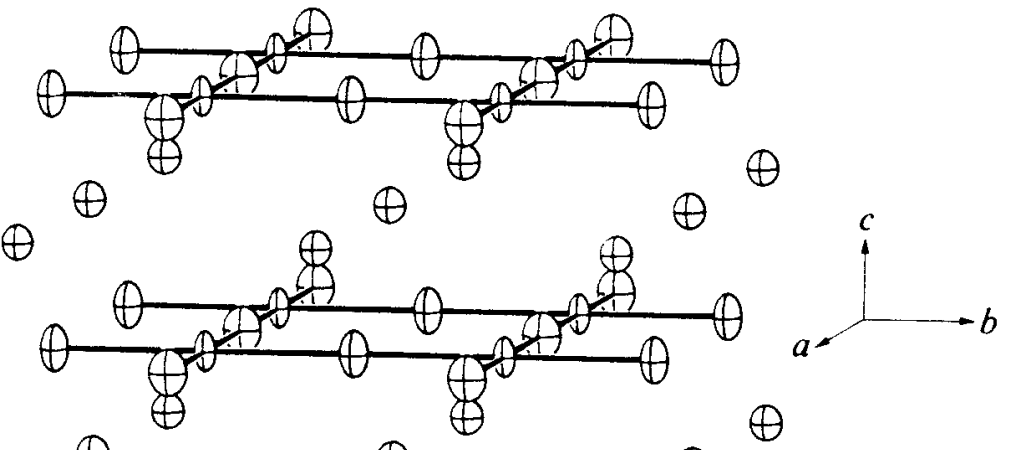

$\oplus$

$\oplus$

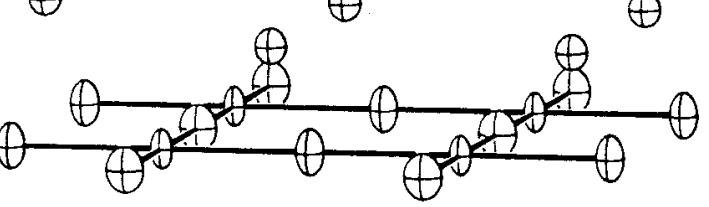

Fig. 33. Extended view of $\left(\mathrm{Ca}_{0.86} \mathrm{Sr}_{0.14}\right) \mathrm{CuO}_{2}$. Only the $\mathrm{Cu}-\mathrm{O}$ bonds are drawn [114].

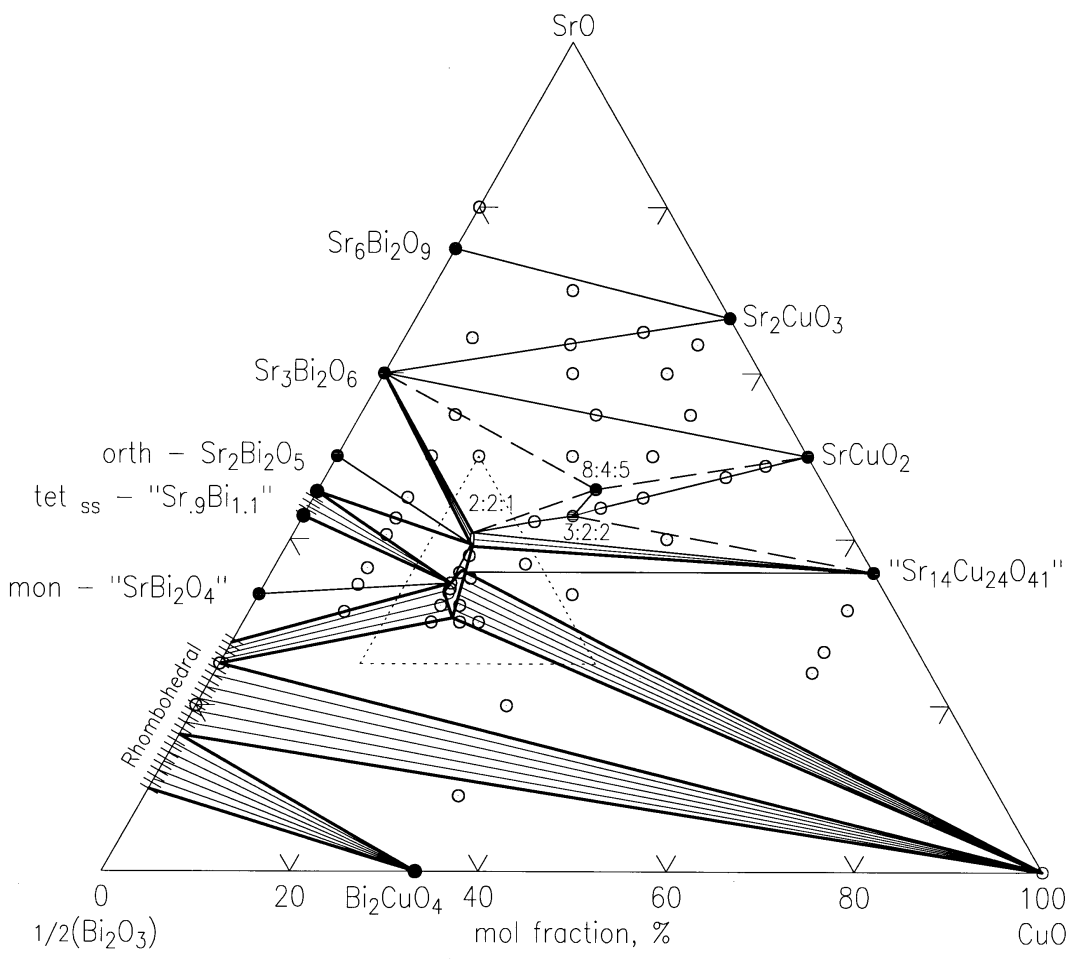

Fig. 34. Phase diagram for the system $\mathrm{SrO}-{ }^{1} / 2 \mathrm{Bi}_{2} \mathrm{O}_{3}-\mathrm{CuO}$. (o)-compositions studied, (•)-compounds. This diagram represents subsolidus conditions, although $\mathrm{Bi}_{2} \mathrm{O}_{3}$ melts at $825^{\circ} \mathrm{C}$ and therefore partial melting occurs below $875^{\circ} \mathrm{C}$ in most compositions below the join CuO-Rhombohedral Solid Solution [115]. 
In this system, several compounds were found to adopt unusual structure. For example, in the structure of $\mathrm{Sr}_{2} \mathrm{Bi}_{2} \mathrm{O}_{5}$ [116], all $\mathrm{Bi}$ atoms are in unusual threefold coordination with respect to oxygen. The compound crystallizes with the space group Amam, and with cell parameters of $a=6.1715(6) \AA, \quad b=14.3066(13) \AA$, $c=3.8261$ (4) $\AA$, and $Z=2$ (PDF 39-1472 [1]). The basic structure consists of the intergrowth of two simple structural elements. The first element is the anti-nickel arsenide structure as shown in Figure 35(a). Each $\mathrm{Sr}$ is surrounded by six nearest neighbors in a trigonal prismatic arrangement. The second structural element can be regarded as $\mathrm{Bi}_{2} \mathrm{O}^{4+}$ chains which are inserted between the anti-NiAs slabs, as shown in Figure 35(b). Bi in 3-coordination with oxygen appears to exist only in systems containing the electropositive alkaline-earth cations $\mathrm{Ca}$ and $\mathrm{Sr}$. These $\mathrm{Sr}$ and $\mathrm{Ca}$ atoms appear to allow the Bi-O bonds to be more covalent in nature and therefore more directional. Ordering of oxygen and vacancies is also visible along the $c$-direction and results in displacements of the $\mathrm{Bi}$ atoms along $c$. The lone pair electrons associated with the $\mathrm{Bi}$ can be envisioned as being directed toward the vacant site as schematically shown in Figure 35(c).

\subsubsection{3 $\mathrm{SrO}-\mathrm{CaO}-\mathrm{Bi}_{2} \mathrm{O}_{3}$}

A large number of solid solution series appear in this system at $800{ }^{\circ} \mathrm{C}$ to $900{ }^{\circ} \mathrm{C}$ due to the substitution of the smaller $\mathrm{Ca}^{+2}$ for the larger $\mathrm{Sr}^{+2}$, as shown in Fig. 36 [117]. The phases of composition $\mathrm{SrO}:{ }^{1} / 2 \mathrm{Bi}_{2} \mathrm{O}_{3}$ of $3: 1$, $3: 2,1: 1,9: 10,1: 2$ accept $\mathrm{CaO}$ to form solid solutions to different extents. The rhombodehral solid solution $\left(\mathrm{Rh}_{\mathrm{ss}}\right)$ is complete across the entire range of $\mathrm{SrO}: \mathrm{CaO}$ ratios. No $\mathrm{SrO}$ has been found in solid solution in either $\mathrm{Ca}_{4} \mathrm{Bi}_{6} \mathrm{O}_{13}$ or $\mathrm{Ca}_{2} \mathrm{Bi}_{2} \mathrm{O}_{5}$. Two ternary new phases (solid

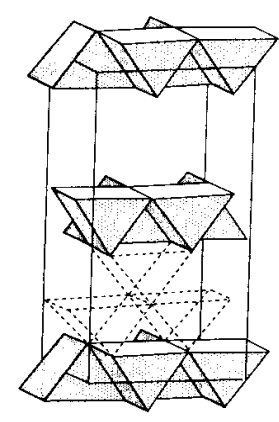

(a)

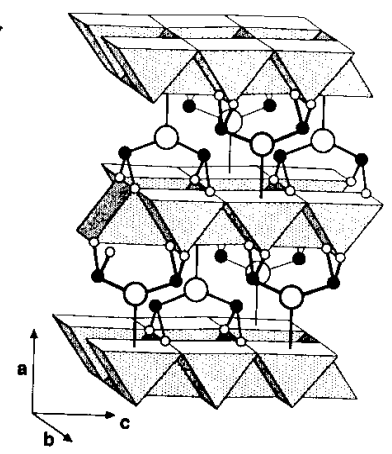

(b) solutions) were discovered. The one with higher $\mathrm{Sr}$ content can be described with a general formula $\mathrm{A}_{4} \mathrm{Bi}_{2} \mathrm{O}_{x}$, and the other one is of general formula $\mathrm{A}_{2} \mathrm{Bi}_{2} \mathrm{O}_{x}$.

$\mathrm{A}_{2} \mathrm{Bi}_{2} \mathrm{O}_{x}\left(\mathrm{Bi}_{16}(\mathrm{Sr}, \mathrm{Ca})_{14} \mathrm{O}_{38}\right)$ crystallizes in the monoclinic space group $C 2 / \mathrm{m}$. A particular composition, $\mathrm{Bi}_{16} \mathrm{Sr}_{5.44} \mathrm{Ca}_{8.56} \mathrm{O}_{38}$, was found to have the cell parameters $a=21.764(4) \AA, b=4.3850(13) \AA, c=12.905(3) \AA$, $\beta=102.7(2)^{\circ}[118,119]$. The Bi positions can be considered as the apices of highly distorted pyramids situated in the channels formed by a network of mixed alkaline-earth oxide polyhedra [Fig. 37(a) and 37(b)]. Two out of four crystallographically distinct $\mathrm{Bi}$ ions form infinite $\mathrm{Bi}-\mathrm{O}$ zigzag ribbons of edge-linked $\mathrm{Bi}-\mathrm{O}$ units, while each of the other two form oxygen cornershared Bi-O chains along $b$. This structure exhibits similar features to $\mathrm{Sr}_{2} \mathrm{Bi}_{2} \mathrm{O}_{5}$ in that they both consist of stacked layers of metal atoms. Tunnels were found between layers which are occupied by Bi lone-pair electrons.

Structural information of $\mathrm{Bi}_{2}(\mathrm{Sr}, \mathrm{Ca})_{4} \mathrm{O}_{x}$ is important for $\mathrm{BSCCO}$ processing because this phase is in equilibrium with the 2201, 2212, and 2223 superconductors. The $\mathrm{Bi}_{2}(\mathrm{Sr}, \mathrm{Ca})_{4} \mathrm{O}_{x}$ solid solution exists in both low-temperature (LT) oxidized form and high-temperature (HT) form. The structure of the LT- form (black) is monoclinic (pseudo-orthorhombic (Fig. 38), with space group $P 2_{1} / n$ [120]. Structural refinements using neutron data gives the lattice parameters of $\left(\mathrm{Bi}_{34} \mathrm{Sr}_{49.5} \mathrm{Ca}_{16.5} \mathrm{O}_{151}\right)$ as: $a=8.38931(16) \AA, b=5.99445(11) \AA, c=5.89572(11)$ $\AA, \beta=89.961(3)^{\circ}$, and $V=296.49(1) \AA^{3}$. This distorted perovskite (described in the perovskite $\mathrm{ABO}_{3}$ formula as $\left.\operatorname{Sr}\left(\mathrm{Bi}_{0.7} \mathrm{Ca}_{0.3}\right) \mathrm{O}_{3}\right)$ features the $1: 1$ ordering of the $\mathrm{M}$ site cations, resulting in the formula $\mathrm{A}_{2} \mathrm{MM}^{\prime} \mathrm{O}_{6}$. The $\mathrm{MO}_{6}$ and $\mathrm{M}^{\prime} \mathrm{O}_{6}$ octahedra are connected to each other via corner-sharing and are tilted with respect to the neighboring layers with an angle of $\approx 15^{\circ}$ around all

Fig. 35. (a) The unit cell of $\mathrm{Sr}_{2} \mathrm{Bi}_{2} \mathrm{O}_{5}$ showing the $\mathrm{SrO}_{6}$ trigonal prisms of $\mathrm{Sr}_{2} \mathrm{O}_{4}$ (dotted polyhedra would complete the NiAs-type structure), and (b), position of $\left[\mathrm{Sr}_{2} \mathrm{O}_{4}\right]^{4+}$ groups, and (c), schematic diagram showing the lone-pair electrons [116]. 


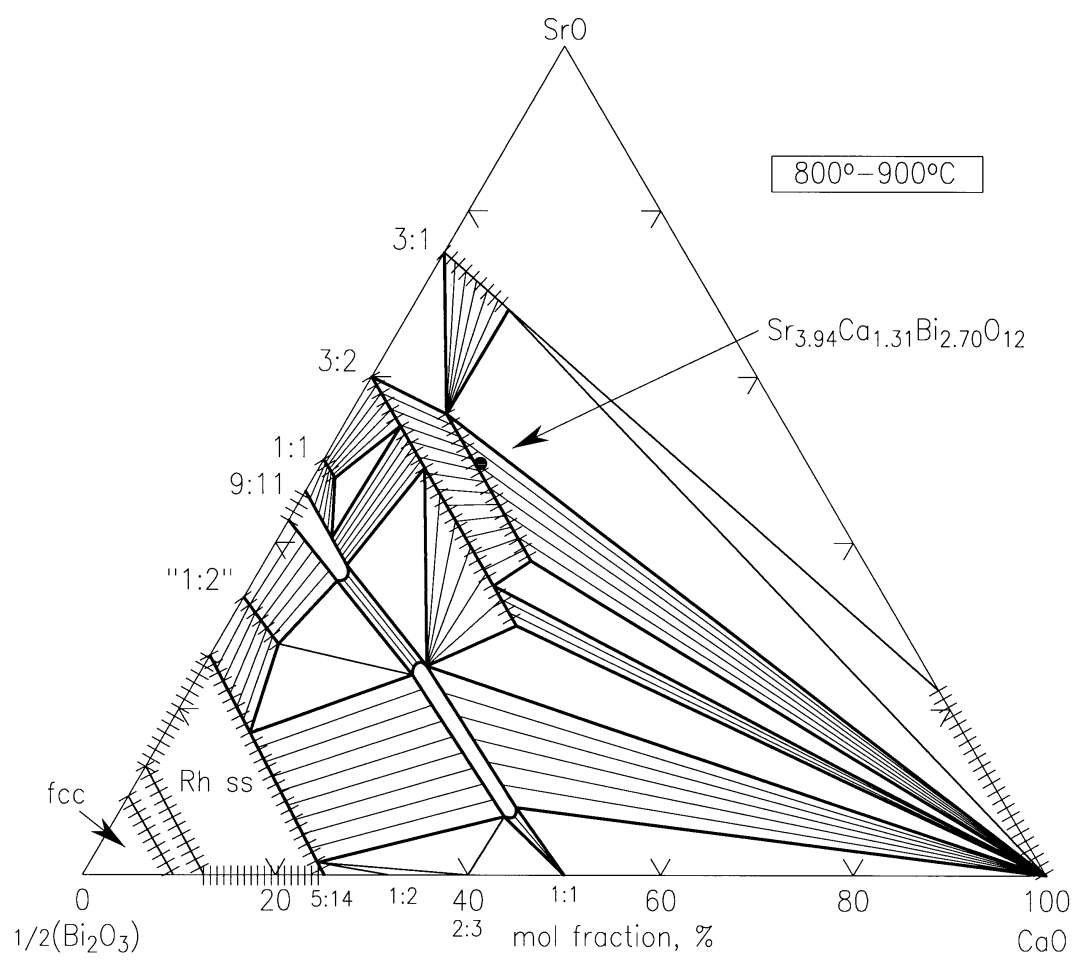

Fig. 36. Phase diagram of the system ${ }^{1} / 2 \mathrm{Bi}_{2} \mathrm{O}_{3}$-SrO-CaO (with experimental data points) showing the solid solution region for $\mathrm{Bi}_{16}(\mathrm{Sr}, \mathrm{Ca})_{14} \mathrm{O}_{38}$ and $\mathrm{Bi}_{2}[\mathrm{Sr}, \mathrm{Ca}]_{4} \mathrm{O}_{x}$ [117].

three axis. The tilt system symbol is $a^{+} a^{-} a^{-}$according to Glazer notation. All Bi ions are in the +5 oxidation state. In this 1:1 ordered structure, the A sites are solely occupied by $\mathrm{Sr}$, the M-sites are mainly by $\mathrm{Bi}(2 \% \mathrm{Ca})$, while on the $M^{\prime}$ sites $\mathrm{Bi}$ and $\mathrm{Ca}$ are distributed in an approximate ratio of $3: 2$.

\subsubsection{Primary Crystallization Field}

The presence of melt has been reported to improve the grain alignment and associated properties of high $T_{\mathrm{c}}$ superconductors in the ( $\mathrm{Bi}, \mathrm{Pb})-\mathrm{Sr}-\mathrm{Ca}-\mathrm{Cu}-\mathrm{O}$ (BSCCO) system [121-122]. In this regard, the powder-in-tube (PIT) processing technique, which involves melt processing, has been found to be a feasible technique for the large-scale production of wires and tapes [123]. Because of the fact that the high $T_{\mathrm{c}}$ phases in the BSCCO systems, similar to the $\mathrm{Ba}-\mathrm{R}-\mathrm{Cu}-\mathrm{O}$ systems, do not melt congruently, for crystal growth or grain growth, it is essential to obtain primary phase information. In the mid-nineties, Wong-Ng and Cook, in collaboration with Kearsley, successfully determined the phase relationship and the primary phase fields of the $\mathrm{Pb}$-free 2212 phase, the $(\mathrm{Bi}, \mathrm{Pb})-2223$ phase, and effect of $\mathrm{Ag}$ on $(\mathrm{Bi}, \mathrm{Pb})-$ 2223.

\subsubsection{2212 Superconductor}

A total of 10 phases was found to be in equilibrium with the 2212 phase [109]. For convenience, symbols (in the order $\mathrm{Bi}: \mathrm{Sr}: \mathrm{Ca}: \mathrm{Cu}$ ) are used to represent the ternary and quaternary oxide phases. The equilibrium phases were 0x21 $\left[(\mathrm{Ca}, \mathrm{Sr})_{2} \mathrm{CuO}_{3}\right], 119 \times 5$ $\left[(\mathrm{Bi}, \mathrm{Pb})_{2.2} \mathrm{Sr}_{1.8-x} \mathrm{Ca}_{x} \mathrm{CuO}_{z}\right], \quad 2110 \quad\left[\mathrm{Bi}_{16}(\mathrm{Sr}, \mathrm{Ca})_{14} \mathrm{O}_{z}\right]$, $014 \times 24\left[(\mathrm{Sr}, \mathrm{Ca})_{14} \mathrm{Cu}_{24} \mathrm{O}_{41}\right], 2310\left[\mathrm{Bi}_{2}(\mathrm{Sr}, \mathrm{Ca})_{4} \mathrm{O}_{z}\right]$, $4805\left[\mathrm{Bi}_{4} \mathrm{Sr}_{8} \mathrm{Cu}_{5} \mathrm{O}_{z}\right), 2201 \quad\left[(\mathrm{Bi}, \mathrm{Pb})_{2} \mathrm{Sr}_{2-x} \mathrm{Ca}_{x} \mathrm{CuO}_{z}\right]$, $(\mathrm{Ca}, \mathrm{Sr}) \mathrm{O}, \mathrm{CuO}$, and 0x11 [( $\left.\left.\mathrm{Sr}_{1-x} \mathrm{Ca}_{x}\right) \mathrm{CuO}_{2}, \mathrm{Ca}-\mathrm{rich}\right]$. Sixteen self-consistent 4-phase equilibrium volumes containing 2212 as a member were determined. The minimum melt compositions of each of these volumes were used to construct the primary phase field (Fig. 39). In this diagram the volume is expressed in Cartesian coordinates and the cotectic faces that are visible in the orientation shown are labeled. The initial melting temperatures are indicated at the corners of the volume. Inside the volume, the 2212 phase is in equilibrium with liquid (L). On each face 2212 is in equilibrium with $\mathrm{L}$ and the labeled phase. Along the edges, 2212 is in equilibrium with two phases plus L, and at the corners, 2212 is in equilibrium with three phases with L. For crystal growth, one should use the composition inside the volume. The crystallization path for a selected composition 
$2 \mathrm{a}$

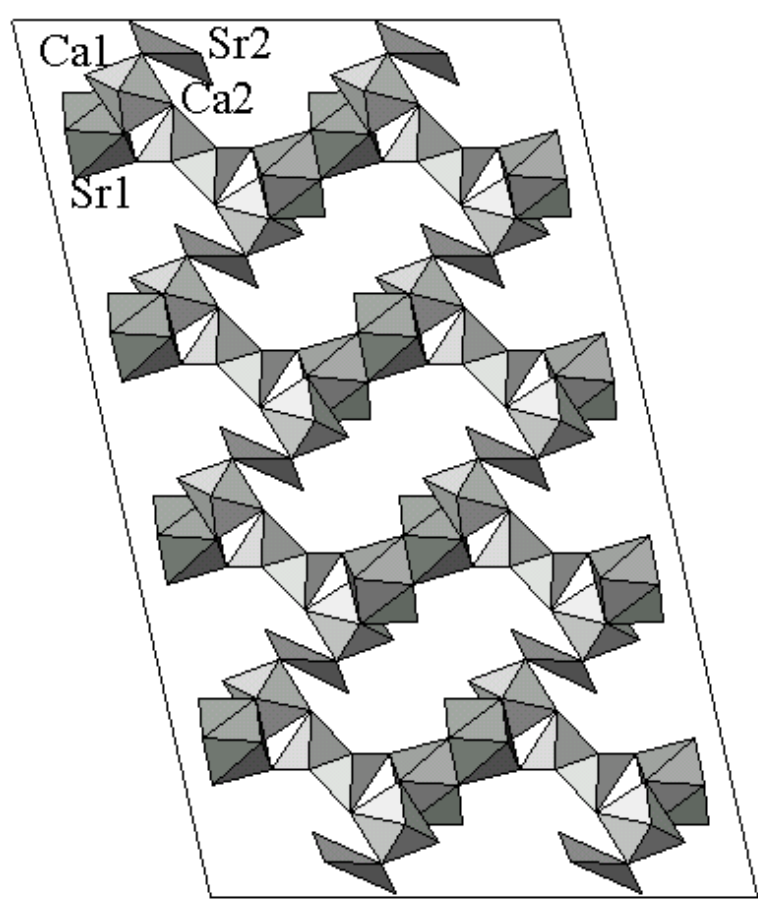

$\mathbf{O}$

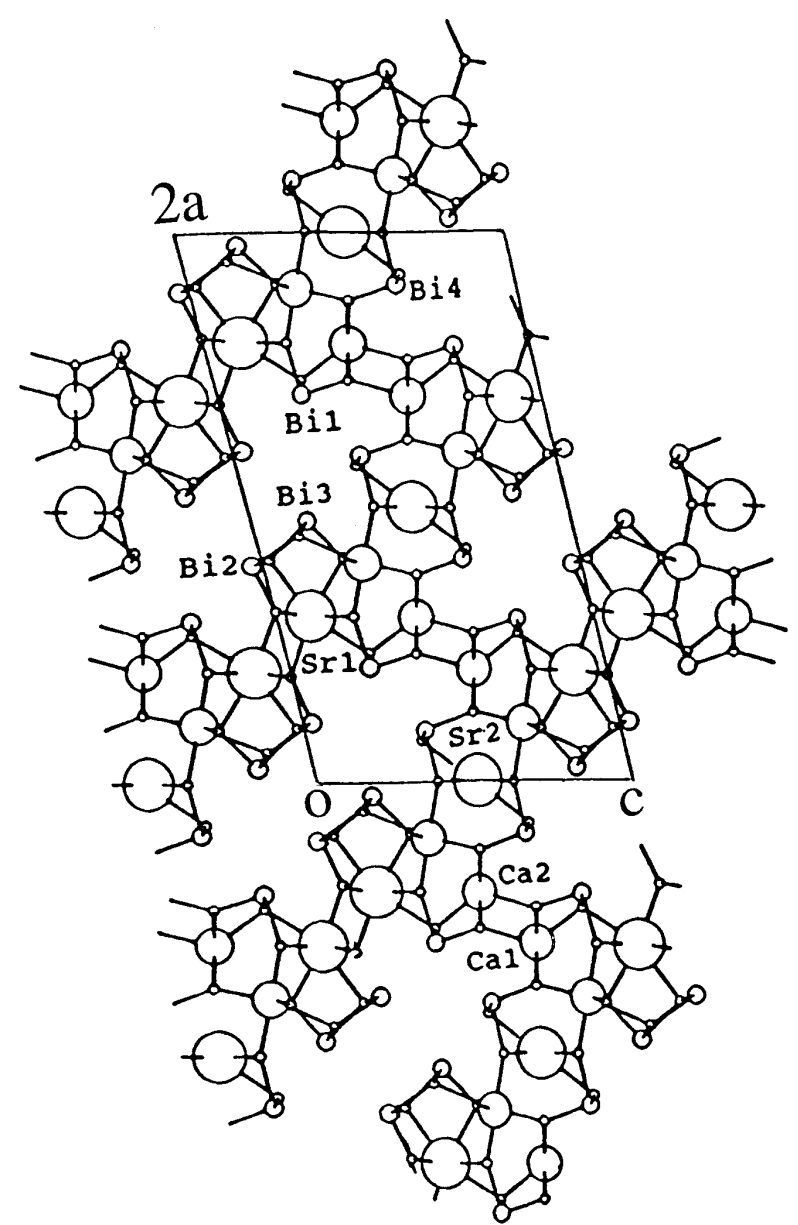

$\mathrm{b}$

Fig. 37. (a) Three-dimensional alkaline-earth oxide polyhedron network of $\mathrm{Bi}_{16} \mathrm{Sr}_{5.44} \mathrm{Ca}_{8.56} \mathrm{O}_{38}$ showing broad channels, and (b) network of $\mathrm{Bi}_{16} \mathrm{Sr}_{5.44} \mathrm{Ca}_{8.56} \mathrm{O}_{38}$ showing concentration of Bi's in the channels [119].

(Bi:Sr:Ca: $\mathrm{Cu}=26.9: 24.7: 17.6: 30.8$ ) is shown. During crystal growth, temperature continues to drop, and when the path is inside the volume, only 2212 crystal crystallizes out. When the path intersects the face and the edge, the $119 \times 5$ phase and $\mathrm{CuO}$ also crystallize, and eventually at the 2212 eutectic temperature, 2110 also appears. Large grains of 2212 can be obtained using this composition. However, if the composition is outside this field even slightly, large second-phase impurities would interfere with processing and have a detrimental effect on properties [124].

\subsubsection{2 (Bi,Pb)2223}

$(\mathrm{Bi}, \mathrm{Pb})-2223$ was found to be in equilibrium with 11 phases, including $(\mathrm{Ca}, \mathrm{Sr}) \mathrm{O}, \mathrm{CuO}, 0 \times 21,2201,119 \times 5$, $1 \times 20\left((\mathrm{Ca}, \mathrm{Sr})_{2} \mathrm{PbO}_{4}\right), 014 \times$ x 24, 2310, 0x11 (Ca-rich), $3221\left((\mathrm{~Pb}, \mathrm{Bi})_{3} \mathrm{Sr}_{2} \mathrm{Ca}_{2} \mathrm{CuO}_{x}\right), 0 \times 11^{\prime}$ (Ca-poor). In these symbols, $\mathrm{x}$ is used to represent the amount of mutual substitution of the $\mathrm{Ca}$ and $\mathrm{Sr}$ sites. At $810{ }^{\circ} \mathrm{C}$ to $820^{\circ} \mathrm{C}$ in volume fraction of $7.5 \% \mathrm{O}_{2}(92.5 \% \mathrm{Ar}), 29$ fivephase volumes that involve the $(\mathrm{Bi}, \mathrm{Pb})-2223$ phase were found to be mutually stable in a topologically consistent manner [110]. The (Bi,Pb)-2223 primary phase field was constructed using the initial melts of these 29 fivephase volumes, and was modeled using the convex hull technique. It is described by the matrix equation: $\boldsymbol{A x}-\boldsymbol{b} \leq 0$, where $\boldsymbol{A}$ is a matrix whose rows define the unit normal vectors to the faces of the convex hull. Each element of the vector $\boldsymbol{b}$ defines the proximity of the given face to the origin. The vector $\boldsymbol{x}$ gives the coordinates corresponding to a given point. Figure 40 shows a projected section made by holding $\mathrm{SrO}$ and $\mathrm{CaO}$ constant at the median values of the data points. The presence of $\mathrm{Ag}$ basically does not alter the subsolidus relationships, but the shape of the primary phase field (Fig. $41)$ is much flattened along the $\mathrm{PbO}$ direction, indicating the $\mathrm{Pb}$ composition in liquid is reduced due to $\mathrm{Ag}$ 


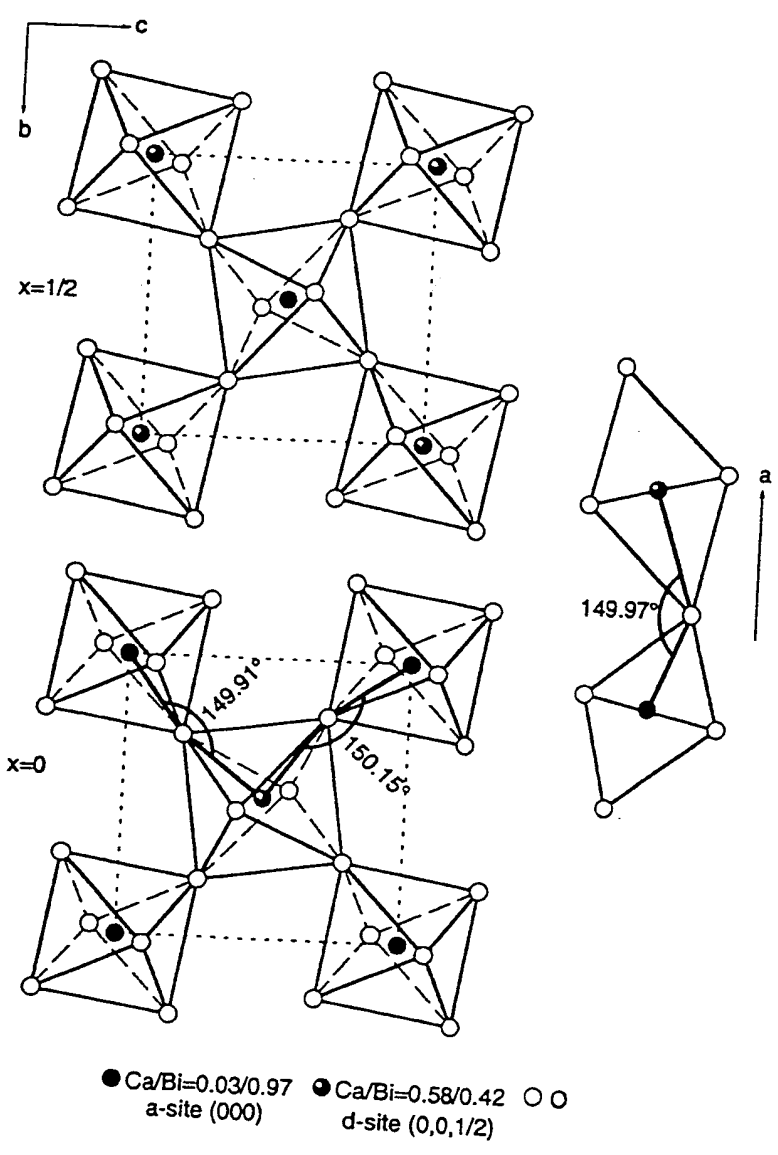

Fig. 38. Schematic drawing of the structure of $\mathrm{LT}-\mathrm{Sr}_{3.94} \mathrm{Ca}_{1.31} \mathrm{Bi}_{2.70} \mathrm{O}_{12}$ showing the $\mathrm{M}-\mathrm{O}-\mathrm{M}$ and $\mathrm{M}^{\prime}-\mathrm{O}^{\prime} \mathrm{M}^{\prime}$ angles of $\approx 15^{\circ}$ about all three axis. The view is approximately along $b[120]$.

[111]. The melting temperatures of the volumes due to the presence of $\mathrm{Ag}$ are consistently lower, from a range of $2{ }^{\circ} \mathrm{C}$ to $25^{\circ} \mathrm{C}$. Ag is present in liquids from $1 \%$ to $6 \%$ mole fraciton. The dissolution of $\mathrm{Ag}$ in melt implies that dissolution of Ag tubing may occur during melt processing.

\subsection{Tl-Containing Systems}

Phase equilibrium studies in the Tl-containing system are not as extensive as those in the $\mathrm{BaO}-\mathrm{Y}_{2} \mathrm{O}_{3}-\mathrm{CuO}$, or the BSCCO systems, partly because of the additional processing parameters of vapor pressure, and also because of the toxicity of the Tl-containing compounds. At NIST, a smaller-scale program was conducted by L. P. Cook and co-workers in the mid-nineties. As a result of this work, the stability of the 2212 ( $\mathrm{Tl}: \mathrm{Ca}: \mathrm{Ba}: \mathrm{Cu}$ ) phase ( $\mathrm{n}=2$ member of the Ruddelsden-Popper homologous series, $\left.\mathrm{Tl}_{2} \mathrm{Ba}_{2} \mathrm{Ca}_{\mathrm{n}-1} \mathrm{Cu}_{\mathrm{n}} \mathrm{O}_{2 \mathrm{n}+3}\right)$ and the solid solution extent was obtained [125]. Figure 42 illustrates the solid solution extent of the 2212 phase in the $\mathrm{Ba}_{2} \mathrm{CaCu}_{2} \mathrm{O}_{2}$ $\mathrm{Tl}_{2} \mathrm{O}_{3}$ system. It was found that a sample with a maxi- mum $T_{\mathrm{c}}$ occurred with less $\mathrm{Tl}_{2} \mathrm{O}_{3}$ than the 2212 stoichiometry.

The properties and stability of the $\mathrm{TlSr}_{2} \mathrm{Ca}_{2} \mathrm{Cu}_{3} \mathrm{O}_{\mathrm{x}}$ (1223) family of phases can be improved by creating pinning centers by partial substitution of $\mathrm{Pb}$ and/or $\mathrm{Bi}$ for $\mathrm{Tl}$ in the rock salt layer, and substitution of $\mathrm{Ba}$ for $\mathrm{Sr}$ in the perovskite layer. The melting and vaporization of the 1223 phase have been investigated using a combination of dynamic methods (differential thermal analysis, thermogravimetry, and effusion) and post-quenching characterization techniques (scanning electron microscopy, energy dispersive x-ray spectrometry, and powder x-ray diffaction) [126]. The melting and vaporization equilibria of the 1223 phase are complex, with as many as seven phases participating simultaneously. The melting reaction was found to be nominally as: $1223 \rightarrow 1212+(\mathrm{Ca}, \mathrm{Sr})_{2} \mathrm{CuO}_{3}+(\mathrm{Sr}, \mathrm{Ca}) \mathrm{CuO}_{2}+$ $(\mathrm{Sr}, \mathrm{Ca}) \mathrm{CuO}_{2}+\mathrm{BaPbO}_{3}+(\mathrm{Ca}, \mathrm{Sr}) \mathrm{O}+\mathrm{L}$.

\subsection{High Pressure Studies of High $T_{\mathrm{c}}$ Superconductors}

Mechanical reliability is critical for the successful applications of high $T_{\mathrm{c}}$ materials. To estimate toughness of a material quantitatively, it is necessary to know the value of Young's modulus for the solid, which can in turn be obtained from the bulk modulus, or its inverse, the compressibility, obtained from high pressure x-ray powder diffraction experiments [127-129]. Both the high $T_{\mathrm{c}}$ superconductor $\mathrm{Ba}_{2} \mathrm{YCu}_{3} \mathrm{O}_{7}$ and the orthorhombic "green phase" $\mathrm{BaLu}_{2} \mathrm{CuO}_{5}$ feature anisotropic compression. The $\mathrm{Ba}_{2} \mathrm{YCu}_{3} \mathrm{O}_{7}$ structure has perovskite-like $\mathrm{CuO}$ layers and chains running perpendicular to the $c$-direction [130]. The largest compression occurred perpendicular to these $\mathrm{CuO}$ layers $(2.3 \%)$. The least compression was found to occur within the perovskitelike layers because of the oxygen packing [ $(2 \%$ in the $a$-direction (oxygen absent in the basal plane) and $1.1 \%$ in $b$-direction ( $\mathrm{Cu}-\mathrm{O}$ chain direction)]. The framework of the green phase can be considered as built up from distorted monocapped trigonal prisms, $\mathrm{RO}_{7}$ blocks. Consecutive layers of the $\mathrm{R}$ prisms are stacked with shared edges to from wave-like chains parallel to the long $b$-axis [128]. The compressibility behavior of $\mathrm{Ba}_{2} \mathrm{YCu}_{3} \mathrm{O}_{7}$ is similar to $\mathrm{BaLu}_{2} \mathrm{CuO}_{5}$ in which greater compression occurs perpendicular to the layer direction (1.2\% in both $a$ - and $b$-directions, and $1.5 \%$ in the $c$-direction). As the bulk modulus of the green phase $\left(\mathrm{BaLu}_{2} \mathrm{CuO}_{5}, 251 \mathrm{GPa}\right)$ is significantly greater than that of $\mathrm{Ba}_{2} \mathrm{YCu}_{3} \mathrm{O}_{7}$ (reported values of bulk modulus range from $55 \mathrm{GPa}$ to $196 \mathrm{GPa}$ ), there is a possibility that mixing the high $T_{\mathrm{c}}$ phase with the green phase (i.e., in fiber form) may result in improved toughness value of the material. 


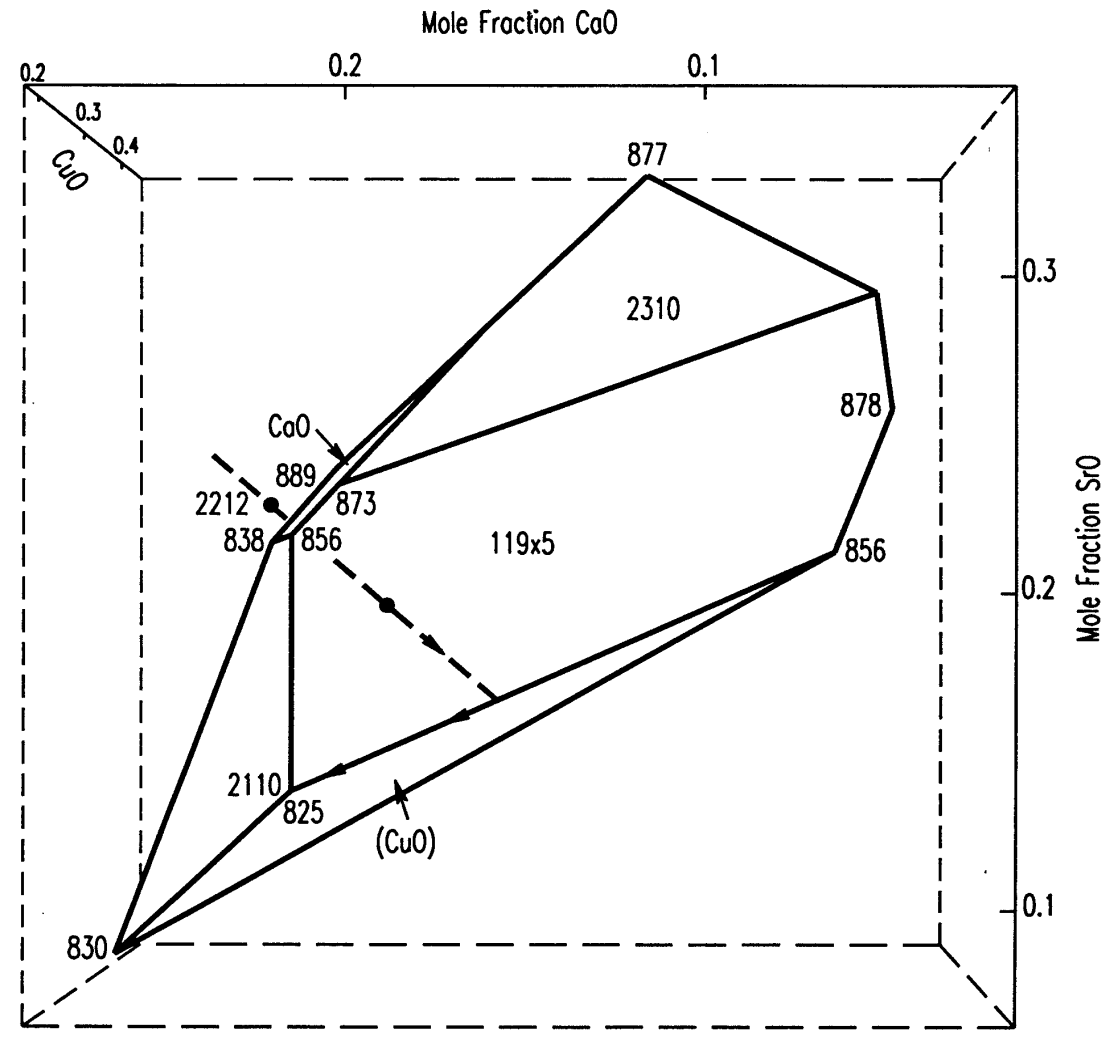

Fig. 39. Primary crystallization field of the 2212 phase in the BSCCO system. A proposed crystallization path is also shown [109].

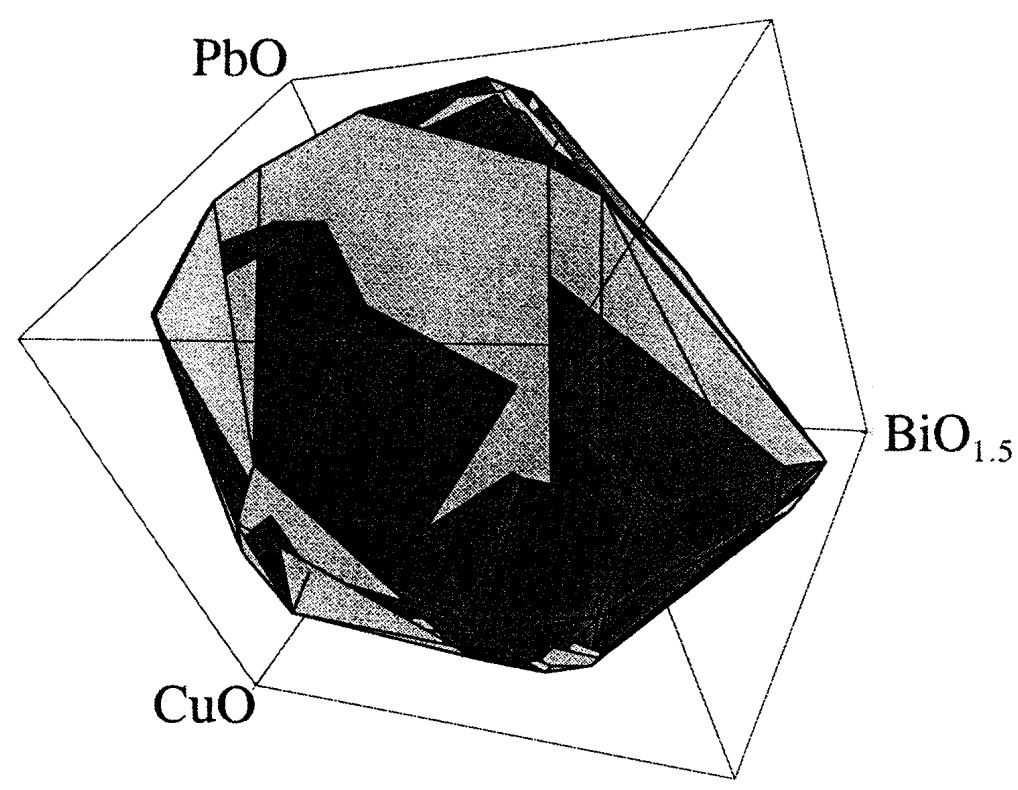

Fig. 40. The primary crystallization field of the $\mathrm{Pb}-2223$ phase. An isoplethal section made by holding the $\mathrm{SrO}$ and $\mathrm{CaO}$ values constant at the medium mole fraction percent for the 29 data points $(\mathrm{SrO}=20.4$, and $\mathrm{CaO}=6.9)[110]$. 


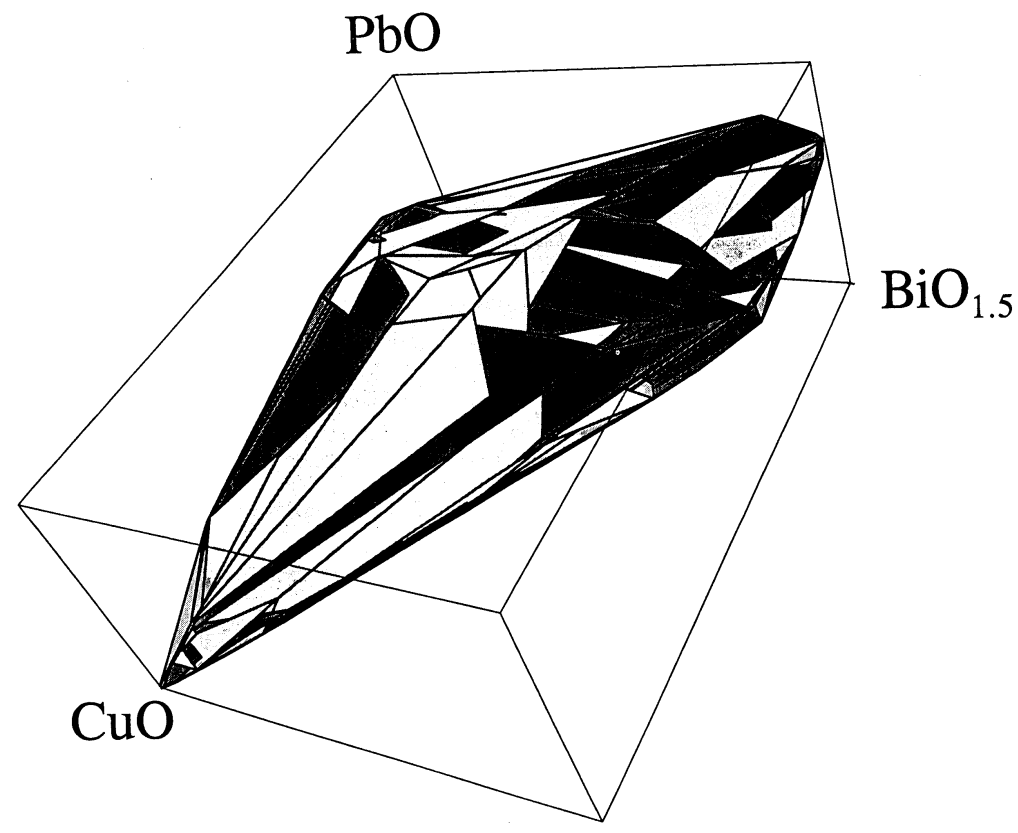

Fig. 41. An isoplethal section of the primary crystallization field of the $\mathrm{Pb}-2223$ phase made by holding the $\mathrm{SrO}, \mathrm{CaO}$, and $\mathrm{Ag}$ values constant at the medium values for the 29 data points (mole fraction percent of $\mathrm{SrO}, \mathrm{CaO}$, and $\mathrm{Ag}=22.8,20.1$, and 3.3, respectively) [111].

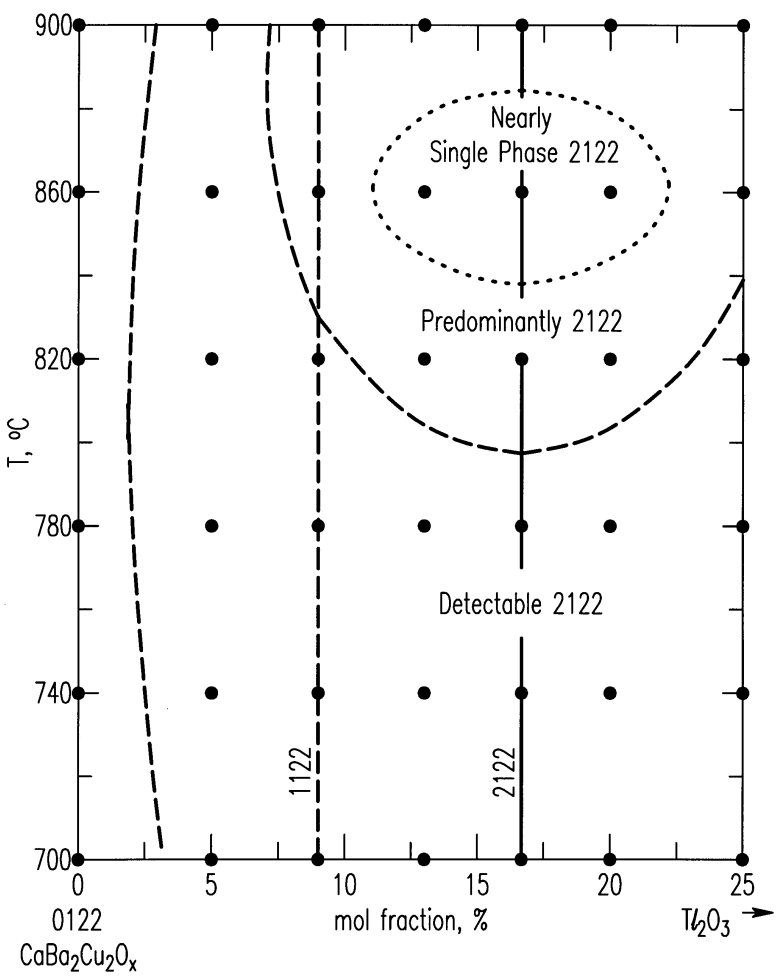

Fig. 42. Temperature-composition plot showing experiments completed under an oxygen atmosphere, with extent of 2212 (Tl:Ca:Ba:Cu) phase formation [125].

\section{Collaboration With the American Ceramic Society-Compilation of Phase Diagrams}

For over 60 years, there has been a long-standing cooperative effort between NBS/NIST and the American Ceramic Society (ACerS) to publish compilations of published phase diagrams [131]. This collaborative effort was initiated as early as in 1933 by H. Insley and F. P. Hall, and the diagrams were published by the ACerS. To date, more than 20000 phase diagrams have been published. There are a total of thirteen volumes of compilations of oxides, salts, semiconductor elements, borides, carbides, and nitrides for structural ceramics; three annual volumes of diagrams published in 1991, 1992, and 1993. In addition, two volumes containing high-temperature superconductor data including diagrams, write-ups and bibliographic information were also published in 1991 and 1997 (Superconductors Volumes I and II). An additional volume of phase diagrams for zirconium and zirconia system was also published in 1998. The sources of these phase diagrams are mostly from the literature, and the data have been reviewed and edited by experts in the field. Under this collaborative effort, technical expertise in the compilation of phase diagrams is provided by NIST researchers, and by various university, industry, and government collaborators. The ACerS assumes the responsibility for the produc- 
tion aspects of the work and for all means of data dissemination.

These diagrams have been used extensively and over 45000 copies of individual volumes have been sold. At the time of the ACerS centennial celebration in 1998, the publication of phase diagrams was cited as one of the two most important accomplishments of the Society affecting the development of ceramics. Today the project is under the leadership of T. A. Vanderah. In addition to the general editors (Robert S. Roth, H. McMurdie, Helen M. Ondik, and L. P. Cook), other individuals who also serve in various capacity to oversee the production of each volume include M. A. Harne, P. Schenck, K. Hill, C. Cedeo, M. Swanson, E. Farabaugh, and C. G. Messina.

\section{References}

[1] Powder Diffraction File (PDF), produced by International Centre for Diffraction Data (ICDD), 12 Campus Blvd., Newtown Square, PA, 19073-3273.

[2] H. F. McMurdie and H. Insley, Studies of the Quaternary System $\mathrm{CaO}-\mathrm{MgO}-2 \mathrm{CaO} \cdot \mathrm{SiO}_{2}-5 \mathrm{CaO} \cdot 3 \mathrm{Al}_{2} \mathrm{O}_{3} \mathbf{1 6}, 467-479$ (1936).

[3] E. P. Flint, H. F.McMurdie, and L. S.Wells, Hydrothermal and X-Ray Studies of the Garnet-Hydrogarnet Series and the Relationships of the Series to Hydration Products of Portland Cement, J. Res. Natl. Bur. Stand. (U.S.) 26, 13-33 (1941).

[4] R. F. Geller, A. S. Creamer, and E. N. Bunting, The System $\mathrm{PbO}-\mathrm{SiO}_{2}$, J. Res. Natl. Bur. Stand. (U.S.) 13, 243 (1934).

[5] H. F.McMurdie and E. N. Bunting, X-Ray Studies of Compounds in the System $\mathrm{PbO}-\mathrm{SiO}_{2}$, J. Res. Natl. Bur. Stand. (U.S.) 23, 543-547 (1939).

[6] E. M. Levin and H. F. McMurdie, The System $\mathrm{BaO}-\mathrm{B}_{2} \mathrm{O}_{3}$, J. Res. Natl. Bur. Stand. (U.S.) 42, 131-137 (1949).

[7] E. M. Levin and G. M. Ugrinic, The System Barium OxideBoric Oxide- Silica, J. Res. Natl. Bur. Stand. (U.S.) 51, 37-56 (1953).

[8] R. S. Roth and E. M. Levin, Phase Equilibria in the Sub-system Barium Disilicate-Dibarium Trisilicate, J. Res. Natl. Bur. Stand. (U.S.) 62 (5), 193-200 (1959).

[9] E. M. Levin and S. Block, Structural Interpretation of Immiscibility in Oxide System, I. Analysis and Calculation of Immiscibility, J. Amer. Ceram. Soc. 40 (3), 95-106 (1957).

[10] S. Block and E. M. Levin, Structural Interpretation of Immiscibility in Oxide System, II. Coordination Principle Applied to Immiscibility, J. Amer. Ceram. Soc. 40 (4), 113-118 (1957).

[11] E. M. Levin, C. R. Robbins, and J. L. Waring, Immiscibility and the System Lanthanum Oxide-Boric Oxide, J. Amer. Ceram. Soc. 44 (3), 87-91 (1961).

[12] H. Insley, H. F. McMurdie, W. H. Parsons, and B. L. Steirman, Some Properties of Materials used for Jewel Instrument Bearings, Amer. Miner. 32 (1-2), 1-15 (1947).

[13] H. F. McMurdie and E. Golovato, Study of the Modifications of Manganese Dioxide, J. Res. Natl. Bur. Stand. (U.S.) 41, 589-600 (1948).

[14] A. Van Valkenburg, Jr. and H. F. McMurdie, High Temperature X-Ray Diffraction Apparatus, J. Res. Natl. Bur Stand. (U.S.) 38, 415-418 (1947).
[15] H. F. McMurdie, D. N. Craig, and G. W. Vinal, A Study of Equilibrium Reactions in the Lechlanche Dry Cells, Trans. Electrochem. Soc. 90, 509-528 (1946).

[16] H. F. McMurdie, Microscopic and Diffraction Studies on Dry Cells and Their Raw Materials, Trans. Electrochem. Soc. 86, 313-326 (1944).

[17] S. M. Lang, F. P. Knudsen, C. L. Fillmore, and R. S. Roth, High Temperature Reactions of Uranium Dioxide With Various Metallic Oxides, Natl. Bur. Stand. Circular 568 (1956).

[18] H. F. McMurdie, S. Block, G. Piermarini, and A. Mighell, private communications.

[19] A. D. Mighell, A. Perloff, and S. Block, The Crystal Structure of the High-temperature Form of Barium Borate, $\mathrm{BaO} \cdot \mathrm{B}_{2} \mathrm{O}_{3}$, Acta Cryst. 20, 819 (1966).

[20] A. Hyman, A. Perloff, F. Mauer, and S. Block, The Crystal Structure of Sodium Tetraborate, Acta Cryst. 22, 815 (1967).

[21] A. D. Mighell and V. L. Karen, NIST Crystallographic Databases for Research and Analysis, J. Res. Natl. Inst. Stand. Technol. (U.S.) 101, 273-280 (1996).

[22] R. S. Roth, Classification of Perovskite and Other $\mathrm{ABO}_{3}$-Type Compounds, J. Res. Natl. Bur. Stand. 58 (2), 75-88 (1957).

[23] T. Negas, R. S. Roth, H. S. Parker, and D. Minor, Subsolidus Phase Relations in the $\mathrm{BaTiO}_{3}-\mathrm{TiO}_{2}$ System, J. Solid State Chem. 9, 297-307 (1974).

[24] P. H. Fang, F. Forrat, and R. S. Roth, Properties Ferroelectriques de $\mathrm{Ba}_{6} \mathrm{Nb}_{28 / 3} \mathrm{Ni}_{2 / 3} \mathrm{O}_{30}$ C. R. Hebd. Seances Acad. Sci. 253, 1039-1041 (1961).

[25] R. S. Roth and P. H. Fang, Ferroelectric and Ferromagnetic Properties of $\left(\mathrm{Ba}_{6-2 x} \mathrm{R}_{2 x}\right)\left(\mathrm{Nb}_{9-x} \mathrm{Fe}_{1+x}\right) \mathrm{O}_{30}$, J. Appl. Phys. 31 (5), 278S (1960).

[26] R. S. Roth, Phase Equilibria in the System Cadmium OxideNiobium Oxide, J. Am. Ceram. Soc. 44 (1), 49-50 (1961).

[27] S. M. Lang, F. P. Knudsen, C. L. Fillmore, and R. S. Roth, High Temperature Reactions of Uranium Dioxide with Various Metal Oxides, NBS Circular 568 (1956).

[28] R. S. Roth, Phase Equilibrium Relations in the Binary System Lead-Oxide-Niobium Pentoxide, J. Res. Natl. Bur. Stand. (U.S.) 62 (1), 27-38 (1959).

[29] R. S. Roth, Unit Cell Data of the Lead Niobate $\mathrm{PbNb}_{2} \mathrm{O}_{6}$, Pt. 6, Acta Cryst. 10, 437 (1957).

[30] G. Goodman, Ferroelectric Properties of Lead Metaniobate, J. Am. Ceram. Soc. 36, 368 (1953).

[31] B. Jaffe, S. Marzullo, and R. S. Roth, Properties of Piezoelectric Ceramics in the Solid Solution Series Lead Titanate-Lead Zirconate-Lead Oxide: Tin Oxide and Lead Titanate-Lead Hafnate, J. Res. Natl. Bur. Stand. (U.S.) 55 (4), 239-254 (1955).

[32] B. Jaffe, S. Marzullo, and R. S. Roth, Piezoelectric Properties of Lead Zirconate-Lead Titanate Solid Solution Ceramics, J. Appl. Phys. 25 (6), 809-810 (1954).

[33] E. M. Levin and R. S. Roth, Polymorphism of Bismuth Sesquioxide. I. Pure $\mathrm{Bi}_{2} \mathrm{O}_{3}$, J. Res. Natl. Bur. Stand. (U.S.) 68A (2), 189-195 (1964).

[34] E. M. Levin and R. S. Roth, Polymorphism of Bismuth Sesquioxide. II. Effect of Oxide Additions on the Polymorphism of $\mathrm{Bi}_{2} \mathrm{O}_{3}$, J. Res. Natl. Bur. Stand. (U.S.) 68A (2), 197206 (1964)

[35] A. Santoro, R. J. Cava, D. W. Murphy, and R. S. Roth, Use of the Pearson Type VII Distribution in the Neutron Profile Refinement of the Structures of $\mathrm{LiReO}_{3}$ and $\mathrm{Li}_{2} \mathrm{ReO}_{3}$ Neutron Scattering-1981, AIP Conference Proceedings 89, Published by the American Institute of Physics (1982) pp. 162-165.

[36] R. J. Cava, A. Santoro, D. W. Murphy, S. Zahurak, and R. S. Roth, Structural Aspects of Lithium Insertion in Oxides: $\mathrm{Li}_{x} \mathrm{ReO}_{3}$ and $\mathrm{Li}_{2} \mathrm{FeV}_{3} \mathrm{O}_{8}$, Solid State Ionics 5, 323-326 (1981). 
[37] R. S. Roth and E. Prince, A Neutron Diffraction Investigation of the Defect Structure of $\mathrm{Li}^{+}$- Doped $\mathrm{Ta}_{2} \mathrm{O}_{5}$, Diffraction Studies of Real Atoms and Real Crystals, Melbourne, Australia, August 19-23, 1974, pp. 197-198.

[38] A. Santoro, R. S. Roth, and M. Austin, Powder Neutron Diffraction Study of the Non-stoichiometric Solid Solution of Lithium Tantalate, $9 \mathrm{LiTaO}_{3}: \mathrm{Ta}_{2} \mathrm{O}_{5}$, Acta Cryst. B38, 1094-1099 (1982).

[39] R. J. Cava, A. Santoro, D. W. Murphy, S. Zahurak, and R. S. Roth, The Structures of Lithium Inserted Metal Oxides: $\mathrm{LiReO}_{3}$ and $\mathrm{Li}_{2} \mathrm{ReO}_{3}$, J. Solid State Chem. 42, 251-262 (1982).

[40] J. L. Hodeau, M. Marezio, A. Santoro, and R. S. Roth, Neutron Profile Refinement of the Structure of $\mathrm{Li}_{2} \mathrm{SnO}_{3}$ and $\mathrm{Li}_{2} \mathrm{ZrO}_{3}, \mathrm{~J}$. Solid State Chem. 45, 170-179 (1982).

[41] J. L. Hodeau, M. Marezio, A. Santoro, and R. S. Roth, Neutron Diffraction Structure Determination of the High Temperature Form of Lithium Tritantalate, H-LiTa $\mathrm{O}_{8}$, J. Solid State Chem. 51, 275-292 (1984).

[42] M. Zocchi, M. Gatti, A. Santoro, and R. S. Roth, Neutron and X-Ray Diffraction Study on Polymorphism in Lithium Orthotantalate, $\mathrm{Li}_{3} \mathrm{TaO}_{4}$, J. Solid State Chem. 48, 420-430 (1983).

[43] R. J. Cava, A. Santoro, D. W. Murphy, S. Zahurak, and R. S. Roth, The Structures of Lithium Inserted Metal Oxides: $\mathrm{Li}_{2} \mathrm{FeV}_{3} \mathrm{O}_{8}$, J. Solid State Chem. 48, 309-311 (1983).

[44] R. S. Roth, Neutron X-Ray Diffraction Study on Polymorphism in Lithium Orthotantalate, $\mathrm{Li}_{3} \mathrm{TaO}_{4}$ : Correction and Discussion, J. Solid State Chem. 51, 403-404 (1984).

[45] R. J. Cava, D. W. Murphy, S. Zahurak, A. Santoro, and R. S. Roth, The Crystal Structure of the Lithium Inserted Metal Oxides $\mathrm{Li}_{0.5} \mathrm{TiO}_{2}$ Anatase, $\mathrm{LiTi}_{2} \mathrm{O}_{4}$, J. Solid State Chem. 53, 64-75 (1984).

[46] R. J. Cava, A. Santoro, D. W. Murphy, S. M. Zahurak, R. M. Fleming, P. Marsh, and R. S. Roth, The Structure of the Lithium Inserted Metal Oxide $\mathrm{LiV}_{2} \mathrm{O}_{5}$, J. Solid State Chem. 65 (1), 63-71 (1986).

[47] M. Zocchi, I. Natali Sora, L. E. Depero, and R. S. Roth, A Single Crystal X-Ray Diffraction Study of Lithium Zirconate, $\mathrm{Li}_{6} \mathrm{Zr}_{2} \mathrm{O}_{7}$, A Solid State Ionic Conductor, J. Solid State Chem. 104, 391-396 (1993).

[48] T. Negas, R. S. Roth, H. S. Parker, and W. S. Brower, Crystal Chemistry of Lithium in Octahedrally Coordinated Structures. I. Synthesis of $\mathrm{Ba}_{8}\left(\mathrm{Me}_{6} \mathrm{Li}_{2}\right) \mathrm{O}_{24} \quad(\mathrm{Me}=\mathrm{Nb}$ or $\mathrm{Ta})$ and $\mathrm{Ba}_{10}\left(\mathrm{~W}_{6} \mathrm{Li}_{4}\right) \mathrm{O}_{30}$, II. The Tetragonal Bronze Phase in the System $\mathrm{BaO}-\mathrm{Nb}_{2} \mathrm{O}_{5}-\mathrm{Li}_{2} \mathrm{O}$, J. Solid State Chem. 8, 1-13 (1973).

[49] R. S. Roth, H. S. Parker, and W. S. Brower, Crystal Chemistry of Lithium in Octahedrally Coordinated Structures, III. A New Structure-Type in the System $\mathrm{K}_{2} \mathrm{O}: \mathrm{Li}_{2} \mathrm{O}: \mathrm{TiO}_{2}\left(\mathrm{~K}_{x} \mathrm{Li}_{x} \mathrm{Ti}_{4-x / 2} \mathrm{O}_{8}\right)$, Mater. Res. Bull. 8, 327-332 (1973).

[50] B. M. Gatehouse, T. Negas, and R. S. Roth, The Crystal Structure of $\mathrm{M}-\mathrm{LiTa}_{3} \mathrm{O}_{8}$ and its Relationship to the Mineral Wodginite, J. Solid State Chem. 18, 1-7 (1976).

[51] G. D. Fallon, B. M. Gatehouse, R. S. Roth, and S. A. Roth, Crystal Structures of Some Niobium and Tantalum Oxides. Part VI. The Structure of $\mathrm{H}-\mathrm{LiTa}_{3} \mathrm{O}_{8}$, J. Solid State Chem. 27, 255259 (1979).

[52] E. Lukacevic, A. Santoro, and R. S. Roth, Neutron Powder Diffraction Study of the Structure of the Compound $\mathrm{Li}_{0.3125} \mathrm{La}_{0.5625} \mathrm{MoO}_{4}$, Solid State Ionics 18\&19, $922-928$ (1986).

[53] P. M. Skarstad, R. S. Roth, C. R. Hubbard, and H. S. Parker, The Crystal Structure of the Cation-Disordered Phase $\left(\mathrm{Tl}_{0.75} \mathrm{~Pb}_{0.25}\right)_{4} \mathrm{Cl}_{5}$, J. Solid State Chem. 30 (1), 65-78 (1979).

[54] R. S. Roth and J. L. Waring, Phase Equilibrium Relations in the Binary System Barium Oxide-Niobium Pentoxide, J. Res. Natl. Bur. Stand. (U.S.) 65A (4), 337-344 (1961).
[55] R. S. Roth and A. D. Wadsley, Multiple Phase Formation in the Binary System $\mathrm{Nb}_{2} \mathrm{O}_{5}-\mathrm{WO}_{3}$. I. Preparation and Identification of Phases, Acta Cryst. 19 (1), 26-32 (1965).

[56] J. L. Waring and R. S. Roth, Effect of Oxide Additions on the Polymorphism of Tantalum Pentoxide (System $\mathrm{Ta}_{2} \mathrm{O}_{5}-\mathrm{TiO}_{2}$ ), J. Res. Natl. Bur. Stand. (U.S.) 72A (2), 175-186 (1968).

[57] R. S. Roth and N. C. Stephenson; Chemical and Structural Investigation in the $\mathrm{Ta}_{2} \mathrm{O}_{5}-\mathrm{WO}_{3}$ System; in Chemistry of Extended Defects in Non-Metallic Solids, North Holland Publishing Co., Amsterdam, North Holland (1970).

[58] R. S. Roth, J. L. Waring, W. S. Brower, Jr., and H. S. Parker, Superstructure of the Orthorhombic $\mathrm{Nb}_{2} \mathrm{O}_{5}-\mathrm{ZrO}_{2}$ Type Phase(s) in the $\mathrm{Nb}_{2} \mathrm{O}_{5}-\mathrm{ZrO}_{2}$ and $\mathrm{Ta}_{2} \mathrm{O}_{5}-\mathrm{ZrO}_{2}$ Systems Proceedings of the 5th Materials Research Symposium-Sold State Chemistry NBS Special Publ. 364 (1972) pp. 183-195.

[59] N. C. Stephenson and R. S. Roth, Structural Systematics in the Binary System $\mathrm{Ta}_{2} \mathrm{O}_{5}-\mathrm{WO}_{3}$. III. The Structure of $45 \mathrm{Ta}_{2} \mathrm{O}_{5^{-}}$ $\mathrm{Al}_{2} \mathrm{O}_{3}-4 \mathrm{WO}_{3}$, Acta Cryst. B27, 1025-1031 (1971).

[60] A. E. McHale and R. S. Roth, Low Temperature Phase Relationships in the System $\mathrm{ZrO}_{2}-\mathrm{TiO}_{2}$, J. Am. Ceram. Soc. 69 (11), 827-832 (1986).

[61] T. Negas and R. S. Roth, Phases in the Systems BaO-NiO-O$\mathrm{CO}_{2}$ and $\mathrm{BaO}-\mathrm{CoO}-\mathrm{O}-\mathrm{CO}_{2}$ Proceedings of the 5th Materials Research Symposium-Solid State Chemistry, NBS Special Publ. 364 (1972) pp. 233-263.

[62] R. S. Roth, C. J. Rawn, C. G. Lindsay, and W. Wong-Ng, Phase Equilibria and Crystal Chemistry of the Binary and Ternary Barium Polytitanates and Crystallography of the Barium Zinc Polytitanates, J. Solid State Chem. 104, 99-118 (1993).

[63] J. M. Millet, R. S. Roth, L. D. Ettlinger, and H. S. Parker, Phase Equilibria and Crystal Chemistry in the Ternary System BaO$\mathrm{TiO}_{2}-\mathrm{Nb}_{2} \mathrm{O}_{5}$ : Part I, J. Solid State Chem. 67, 259-270 (1987).

[64] R. S. Roth, L. D. Ettlinger, and H. S. Parker, Phase Equilibria and Crystal Chemistry in the Ternary System $\mathrm{BaO}-\mathrm{TiO}_{2}-\mathrm{Nb}_{2} \mathrm{O}_{5}$ : Part II. New Barium Polytitanates with $<5 \mathrm{~mol} \% \mathrm{Nb}_{2} \mathrm{O}_{5}, \mathrm{~J}$. Solid State Chem. 68, 330-339 (1987).

[65] D. Kolar, S. Gaberscek, B. Volavsek, H. S. Parker, and R. S. Roth, Synthesis and Crystal Chemistry of $\mathrm{BaNd}_{2} \mathrm{Ti}_{3} \mathrm{O}_{10}$, $\mathrm{BaNd}_{2} \mathrm{Ti}_{5} \mathrm{O}_{14}$, and $\mathrm{Nd}_{4} \mathrm{Ti}_{9} \mathrm{O}_{24}$, J. Solid State Chem. 38, 158-164 (1981).

[66] R. S. Roth, A. D. Wadsley, and B. M. Gatehouse, Composition of the Phases in the Systems $\mathrm{NbO}_{2}-\mathrm{Nb}_{2} \mathrm{O}_{5}$ and $\mathrm{TiO}_{2}-\mathrm{Nb}_{2} \mathrm{O}_{5}$, Naturwissenschaften 51 (11) (1964).

[67] P. K. Davies and R. S. Roth, Defect Intergrowths in Barium Polytitanates: (1) $\mathrm{Ba}_{2} \mathrm{Ti}_{9} \mathrm{O}_{20}$, J. Solid State Chem. 71, 490-502 (1987).

[68] P. K. Davies and R. S. Roth, Defect Intergrowths in Barium Polytitanates: (1) $\mathrm{BaTi}_{5} \mathrm{O}_{11}$, J. Solid State Chem. 71, 503-512 (1987).

[69] A. Olsen and R. S. Roth, Crystal Structure Determination of $\mathrm{BaNd}_{2} \mathrm{Ti}_{3} \mathrm{O}_{10}$ Using High Resolution Electron Microscopy, J. Solid State Chem. 60, 347-357 (1985).

[70] C. J. Rawn, D. P. Birnie III, M. A. Bruck, J. H. Enemark, and R. S. Roth, Structural Investigation of $\mathrm{Ba}_{6-3 x} \mathrm{Ln}_{8+2 x} \mathrm{Ti}_{18} \mathrm{O}_{54}$ $(x=0.27, \mathrm{Ln}=\mathrm{Sm})$ by Single Crystal X-Ray Diffraction in Space Group Pnma (No. 62), J. Mater. Res. 13 (1), 187-196 (1998).

[71] T. A. Vanderah, J. M. Loezos, and R. S. Roth, Magnetic Dielectric Oxides: Subsolidus Phase Relations in the $\mathrm{BaO}: \mathrm{Fe}_{2} \mathrm{O}_{3}: \mathrm{TiO}_{2}$ System, J. Solid State Chem. 121, 38-50 (1996).

[72] T. A.Vanderah, et al., Phase Equilibria of the $\mathrm{SrO}-\mathrm{Nb}_{2} \mathrm{O}_{5}-\mathrm{TiO}_{2}$ System, in preparation.

[73] J. Y. Chan, I. Levin, T. A. Vanderah, R. G. Geyer, and R. S. Roth, Subsolidus Phase Relations and Dielectric Properties in the $\mathrm{SrO}-\mathrm{Al}_{2} \mathrm{O}_{3}-\mathrm{Nb}_{2} \mathrm{O}_{5}$ System, Int'l J. Inorg. Mats. 2 (1), 107114 (2000). 
[74] T. A. Vanderah, W. Febo, J. Y. Chan, R. S. Roth, J. M. Loezos, L. D. Rotter, R. G. Geyer, and D. B. Minor, Phase Equilibria and Dielectric Behavior in the $\mathrm{CaO}-\mathrm{Al}_{2} \mathrm{O}_{3}-\mathrm{Nb}_{2} \mathrm{O}_{5}$ System, J. Solid State Chem. 155, 78-85 (2000).

[75] T. A. Vanderah, T. R. Collins, W. Wong-Ng, I. Levin, R. S. Roth, and L. Farber, Phase Equilibria and Crystal Chemistry in the $\mathrm{BaO}-\mathrm{Al}_{2} \mathrm{O}_{3}-\mathrm{Nb}_{2} \mathrm{O}_{5}$ and $\mathrm{BaO}-\mathrm{Nb}_{2} \mathrm{O}_{5}$ Systems, submitted to Int'l Inorg. Mats.

[76] I. E. Grey, R. S. Roth, G. Mumme, L. A. Bendersky, and D. Minor, Crystal Chemistry of New Calcium Tantalate Dielectric Materials, Solid State Chemistry of Inorganic Materials II, MRS Special Publication 547 (1999) p. 127.

[77] I. E. Grey, C. Li, L. M. D. Cranswick, R. S. Roth, and T. A. Vanderah, Structure Analysis of the $6 \mathrm{H}-\mathrm{Ba}\left(\mathrm{Ti}_{1}, \mathrm{Fe}^{3+}, \mathrm{Fe}^{4+}\right) \mathrm{O}_{3-x}$ Solid Solution, J. Solid State Chem. 135, 313-321 (1998).

[78] T. A. Vanderah, W. Wong-Ng, Q. Huang, R. S. Roth, R. G. Geyer, and R. B. Goldfarb, Crystal Structures and Properties of $\mathrm{Ba}_{4} \mathrm{Fe}_{2} \mathrm{Ti}_{10} \mathrm{O}_{27}$ and $\mathrm{Ba}_{3} \mathrm{Fe}_{10} \mathrm{TiO}_{20}$, J. Phys. Chem. Solids 58 (9), 1403-15 (1997).

[79] T. A. Vanderah, W. Wong-Ng, B. H. Toby, V. M. Browning, R. G. Geyer, R. D. Shull, and R. S. Roth, Characterization of Ternary Compounds in the $\mathrm{BaO}: \mathrm{Fe}_{2} \mathrm{O}_{3}: \mathrm{TiO}_{2}$ System: $\mathrm{Ba}_{6} \mathrm{Fe}_{45} \mathrm{Ti}_{17} \mathrm{O}_{106}$ and $\mathrm{BaFe}_{11} \mathrm{Ti}_{3} \mathrm{O}_{23}$, J. Solid State Chem. 143, 182-197 (1999).

[80] T. Siegrist, C. Svensson, T. A. Vanderah, and R. S. Roth, Structural Study of $\mathrm{Ba}_{11} \mathrm{Fe}_{8} \mathrm{Ti}_{9} \mathrm{O}_{41}$ by X-Ray Diffraction, Solid State Sci. 2, 539-544 (2000).

[81] T. Siegrist, T. A. Vanderah, A. P. Ramirez, R. G. Geyer, and R. S. Roth, Crystal Structure and Properties of $\mathrm{Ba}_{5} \mathrm{Fe}_{4} \mathrm{Ti}_{10} \mathrm{O}_{31}, \mathrm{~J}$. Alloys Compounds 274, 169-78 (1998).

[82] A. R. Drew, W. Wong-Ng, R. S. Roth, and T. A. Vanderah, Preparation and Crystal Structure of $\mathrm{Sr}_{5} \mathrm{TiNb}_{4} \mathrm{O}_{17}$, Mater. Res. Bull. 31 (2), 153 (1996).

[83] A. R. Drews, W. Wong-Ng, R. S. Roth, and T. Vanderah, Preparation and Crystal Structure of $\mathrm{Sr}_{6} \mathrm{TiNb}_{4} \mathrm{O}_{18}$, J. Alloys Comp. 255, 243 (1997).

[84] J. M. Loezos, T. A. Vanderah, A. R. Drews, and R. S. Roth, A Series of Chemically Twinned Rutile Oxides, $\operatorname{SrM}_{2 n+1} \mathrm{O}_{4 n+5}$ $(\mathrm{M}=\mathrm{Ti}, \mathrm{Nb} ; n=3 \rightarrow 9)$, Powd. Diffr. 12 (2), 117-125 (1997).

[85] V. S. Kemmler-Sack and U. Treiber, Die Struktur der Rhomboedrischen L-Stapelvarianten $\mathrm{Ba}_{3} \mathrm{~W}_{2-\mathrm{x}}{ }^{\mathrm{VI}} \mathrm{Nb}_{\mathrm{x}}{ }^{\mathrm{V}} \square \mathrm{O}_{9-\mathrm{x} / 2} \square_{\mathrm{x} / 2}, \mathrm{Z}$. Anorg. Allg. Chem. 478, 198 (1981).

[86] T. A. Vanderah, R. S. Roth, and H. F. McMurdie, Phase Diagrams for High $T_{\mathrm{c}}$ Superconductors, The American Ceramic Society, Westerville, OH (1991).

[87] J. D. Whitler and R. S. Roth, Phase Diagrams for High $T_{\mathrm{c}}$ Superconductors, The American Ceramic Society, Westerville, OH (1991).

[88] D. L. Kaiser and L. F. Schneemeyer, Single Crystal Growth, Handbook of Superconductivity, Materials Research Soc., in press.

[89] W. Wong-Ng, Phase Diagrams of High Temperature Superconductors, Handbook of Superconductivity, C. Poole, ed., Academic Press (2000) Chap. 14, pp. 625-685.

[90] W. Wong-Ng, Crystal Structures and Crystal Chemistry of BiContaining Compounds in the Bi-Sr-Ca-Cu-O System, in Studies of High Temperature Superconductors (Advances in Research and Applications, Vol. 25, Chemistry and Related Aspects of High Temperature Superconductors, A. Narlikar, ed., Nova Science Publishers Inc., Commack, NY (1997) pp. 95-133.

[91] W. Wong-Ng, Superconductors: Structures and Applications, in Industrial Applications of X-Ray Diffraction, D. K. Smith and F. Chung, eds., Marcel Dekker Publisher, New York (1999) pp. 89-127.
[92] W. Wong-Ng and S. W. Freiman, Superconducting Phase Formation in $\mathrm{Bi}(\mathrm{Pb})-\mathrm{Sr}-\mathrm{Ca}-\mathrm{Cu}-\mathrm{O}$ Glasses: A Review, in Superconducting Glass-Ceramics in Bi-Sr-Ca-Cu-O: Fabrication and its Application, Y. Abe, ed., World Scientific Publishing Co., Ltd., Singapore (1997) pp. 1-15.

[93] R. S. Roth, C. J. Rawn, F. Beech, J. D. Whitler, and J. O. Anderson, Phase Equilibria in the System Ba-Y-Cu-O-CO $\mathrm{CO}_{2}$ in Air, Ceramic Superconductors II, Research Update, M. F. Yan, ed., The American Ceramic Society, Westerville, Ohio (1988) pp. 13-26.

[94] W. Wong-Ng, L. P. Cook, C. K. Chiang, L. Swartzendruber, L. H. Bennett, J. E. Blendell, and D. Minor, Structural Phase Transition Study of $\mathrm{Ba}_{2} \mathrm{YCu}_{3} \mathrm{O}_{6+x}$ in Air, J. Mater. Res. 3 (5), 832 (1988)

[95] S. R. Foltyn, P. Tiwari, R. C. Dye, M. Q. Le, and X. D. Wu, Pulsed Laser Deposition of Thick $\mathrm{YBa}_{2} \mathrm{Cu}_{3} \mathrm{O}_{7-x}$ Films with Jc $>1 \mathrm{MA} / \mathrm{cm}^{2}$, Appl. Phys. Lett. 63 (13), 1849-1850 (1993).

[96] A. Goyal, D. P. Norton, J. D. Budai, M. Paranthama, E. D. Specht, D. M. Kroeger, D. K. Christen, Q. He, B. Saffian, F. A. List, D. F. Lee, P. M. Martin, C. E. Klabunde, E. Hartfield, and V. K. Sikka, Appl. Phys. Lett. 69 (12), 1795-1797 (1996).

[97] W. Wong-Ng, J. Suh, and L. P. Cook, Subsolidus Phase Relationships of the $\mathrm{BaO}-\mathrm{Y}_{2} \mathrm{O}_{3}-\mathrm{CuO}_{x}$ System Under CarbonateFree Conditions at $p_{\mathrm{O} 2}=100 \mathrm{~Pa}$ and at $p_{\mathrm{O} 2}=21 \mathrm{kPa}$, Physica C, in press.

[98] D. L. Kaiser, F. W. Gayle, R. S. Roth, and L. J. Swartzendruber, Thermomechanical Detwinning of Superconducting $\mathrm{YBa}_{2} \mathrm{Cu}_{3} \mathrm{O}_{7-x}$ Single Crystals, J. Mater. Res. 4 (4), 745-747 (1989).

[99] W. Wong-Ng, F. Gayle, D. Kaiser, S. F. Watkins, and F. Fronzcek, X-Ray Crystallographic Studies of a Thermomechanically Detwinned Single Crystal of $\mathrm{Ba}_{2} \mathrm{YCu}_{3} \mathrm{O}_{6+x}$, Phys. Rev. B 41, 4220 (1990).

[100] W. Wong-Ng and L. P. Cook, Liquidus Diagram of the Ba-Y$\mathrm{Cu}-\mathrm{O}$ System in the Vicinity of the $\mathrm{Ba}_{2} \mathrm{YCu}_{3} \mathrm{O}_{6+x}$ Phase Field, J. Res. Natl. Inst. Stand. Technol. 103, 379 (1998).

[101] W. Wong-Ng, B. Paretzkin, and E. Fuller, Jr., Crystal Chemistry and Phase Equilibria Studies of the $\mathrm{BaO}-\mathrm{R}_{2} \mathrm{O}_{3}-\mathrm{CuO}$ systems. IV. Subsolidus Phase Relationships Near the CuO-Rich Regions, J. Solid State Chem. 85, 117 (1990).

[102] W. Wong-Ng, L. P. Cook, J. Suh, R. Coutts, J. Stalick, I. Levin, and Q. Huang, $\mathrm{BaO}-\mathrm{Nd}_{2} \mathrm{O}_{3}-\mathrm{CuO}_{x}$ Subsolidus Equilibria Under Carbonate-Free Conditions at $p_{\mathrm{O} 2}=100 \mathrm{~Pa}$ and at $p_{\mathrm{O} 2}=21 \mathrm{kPa}$, to be submitted to J. Solid State Chem.

[103] W. Wong-Ng, L. P. Cook, C. K. Chiang, M. D. Vaudin, D. L. Kaiser, F. Beech, L. J. Swartzendruber, L. J. Bennett, and E. R. Fuller, Jr., Structural phase transition studies of $\mathrm{Ba}_{2} \mathrm{RCu}_{3} \mathrm{O}_{6+x}$ in air, in High Temperature Superconducting Compounds: Processing \& Related Properties, S. H. Whang and A. DasGupta, eds., The Minerals, Metals \& Mater. Soc., Warrendale, PA (1989) p. 553.

[104] W. Wong-Ng, L. P. Cook, B. Paretzkin, M. D. Hill, and J. K. Stalick, Crystal Chemistry and Phase Equilibrium Studies of the $\mathrm{BaO}-2 \mathrm{R}_{2} \mathrm{O}_{3}-\mathrm{CuO}_{x}$ Systems in Air, VI. $\mathrm{R}=$ Neodymium, $\mathrm{J}$. Am. Ceram. Soc. 77 (9), 2354 (1994).

[105] B. Okai, High Pressure Synthesis of Superconducting $\mathrm{YSr}_{2} \mathrm{Cu}_{3} \mathrm{O}_{y}$, Jpn. J. Appl. Phys. 29, L2180 (1990).

[106] T. Den and T. Kobayashi, Preparation and Properties of $\mathrm{YSr}_{2} \mathrm{Cu}_{3-x} \mathrm{M}_{x} \mathrm{O}_{y}(\mathrm{M}=\mathrm{Li}, \mathrm{Al}, \mathrm{Ti}, \mathrm{V}, \mathrm{Cr}, \mathrm{Fe}, \mathrm{Co}, \mathrm{Ga}, \mathrm{Ge}, \mathrm{Mo}, \mathrm{W}$, and Re) Physica C 196, 141 (1992).

[107] W. Wong-Ng, J. A. Kaduk, I. Levin, W. Greenwood, and J. Dillingham, Powder X-Ray Reference Patterns of $\mathrm{Sr}_{2} \mathrm{RGaCu}_{2} \mathrm{O}_{7}(\mathrm{R}=\mathrm{Pr}, \mathrm{Nd}, \mathrm{Sm}, \mathrm{Eu}, \mathrm{Gd}, \mathrm{Dy}, \mathrm{Ho}, \mathrm{Er}, \mathrm{Tm}, \mathrm{Yb}$, and Y), J. Res. Natl. Inst. Stand. Technol. 106, 691-707 (2001). 
[108] W. Wong-Ng, Q. Huang, I. Levin, J. A. Kaduk, J. Dillingham, T. Haugan, J. Suh, and L. P. Cook, Crystal Chemistry and Phase Equilibria of Selected $\mathrm{SrO}-\mathrm{R}_{2} \mathrm{O}_{3}-\mathrm{CuO}_{x}$ and Related Systems, $\mathrm{R}=$ Lanthanides and Yttrium, Inter. J. Inorg. Mater. 3, 1283 (2001).

[109] W. Wong-Ng, L. P. Cook, and F. Jiang, Melting Equilibria of the Bi-Sr-Ca-Cu-O (BSCCO) System in Air. I. The Primary Crystallization Phase Field of the 2212 Phase and the Effect of Ag Addition, J. Am. Ceram. Soc. 81 (7), 1829 (1998).

[110] W. Wong-Ng, L. P. Cook, W. Greenwood, and A. Kearsley, Primary Phase Field of the Pb-doped 2223 High $T_{\mathrm{c}}$ Superconductor in the (Bi,Pb)-Sr-Ca-Cu-O System, J. Res. Natl. Inst. Stand. Technol. 104, 277 (1999).

[111] W. Wong-Ng, L. P. Cook, W. Greenwood, and Anthony Kearsley, Effect of $\mathrm{Ag}$ on the Primary Phase Field of High $T_{\mathrm{c}}(\mathrm{Bi}, \mathrm{Pb})-$ 2223 Superconductor, J. Mater Res. 15 (2), 296-305 (2000).

[112] L. E. Orgel, The Stereochemistry of B Subgroup Metals, Part II. The Inert Pair, J. Chem Soc. 3815 (1959).

[113] R. S. Roth, C. J. Rawn, J. J. Ritter, and B. Burton, Phase Equilibria of the System SrO-CaO-CuO, J. Am. Ceram. Soc. 72 (8), 1545-1549 (1989).

[114] T. Siegrist, S. M. Zahurak, D. W. Murphy, and R. S. Roth, The Parent Structure of the Layered High Temperature Superconductors, Nature 334, 232-232 (1988).

[115] R. S. Roth, C. J. Rawn, B. P. Burton, and F. Beech, Phase Equilibria and Crystal Chemistry in Portions of the System SrO-CaO- $-\mathrm{Bi}_{2} \mathrm{O}_{3}-\mathrm{CuO}$. Part II. The System $\mathrm{SrO}-\mathrm{Bi}_{2} \mathrm{O}_{3}-\mathrm{CuO}$, J. Res. Natl. Inst. Stand. Technol. 95 (3), 291-335 (1990).

[116] C. J. Torardi, J. B. Parise, A. Santoro, C. J. Rawn, R. S. Roth, and B. P. Burton, $\mathrm{Sr}_{2} \mathrm{Bi}_{2} \mathrm{O}_{5}$ : A Structure Containing Only 3-Coordinatetd Bismuth, J. Solid State Chem. 93, 228-235 (1991).

[117] C. J. Rawn, R. S. Roth, B. P. Burton, and M. D. Hill, Phase Equilibria and Crystal Chemistry in Portions of the System SrO-CaO- $1 / 2 \mathrm{Bi}_{2} \mathrm{O}_{3}-\mathrm{CuO}$ : V. The System SrO-CaO- $\mathrm{Bi}_{2} \mathrm{O}_{3}, \mathrm{~J}$. Am. Ceram. Soc. 77 (8), 2173-2178 (1994).

[118] W. Wong-Ng, F. Jiang, and G. J. McCarthy, Powder X-Ray Diffraction Characterization of $\mathrm{Bi}_{14}(\mathrm{Sr}, \mathrm{Ca})_{12} \mathrm{O}_{33}$ Solid Solution, Powder Diffr. 11, 268 (1996).

[119] W. Wong-Ng, R. S. Roth, and C. J. Rawn, Preparation and Structural Investigation of $\mathrm{Bi}_{16}(\mathrm{Sr}, \mathrm{Ca})_{14} \mathrm{O}_{38}$, J. Am. Ceram. Soc. 80 (2), 324 (1997).

[120] W. Wong-Ng, J. A. Kaduk, Q. Huang, and R. S. Roth, Crystal Structure of Monoclinic Perovskite $\mathrm{Sr}_{3.94} \mathrm{Ca}_{1.31} \mathrm{Bi}_{2.7} \mathrm{O}_{12}$, Powder Diffr. 15 (4), 227 (2000).

[121] W. Zhang and E. E. Hellstrom, The Development of an Aligned Microstructure During Melt Processing of $\mathrm{Bi}_{2} \mathrm{Sr}_{2} \mathrm{CaCu}_{2} \mathrm{O}_{x}$ (BSCCO-2212) Doctor-Bladed Films, Physica C 218, 141 (1993).

[122] U. Balachandran, A. N. Iyer, P. Haldar, J. G. Hohen, Jr., and L. R. Motowidlo, Progress in Development of Tapes and Magnets Made From Bi-2223 Superconductors, Proceedings of The Fourth International Conference and Exhibition: World Congress on Superconductivity, Vol. II, K. Kristen and C. Burnham, eds., Orlando, FL, June 27-July 1, 1994, pp. 639-649.

[123] H. Sandhage, G. N. Riley, Jr., and W. Carter, Critical Issues in the OPIT Processing of High- $J_{\mathrm{c}}$ BSCCO Superconductors, J. Metal 43, 21 (1991).

[124] L. P. Cook and W. Wong-Ng, Primary Crystallization Volume of BSCCO 2212: Applications to Crystal Growth and Melt Processing, in Ceramics Transaction, Vol. 84, Impact of Recent Advances in Synthesis and Processing of Ceramic Superconductors, W. Wong-Ng, U. Balachandran, and A. S. Bhalla, eds., Am. Ceram. Soc., Westerville, OH (1998) p. 41.

[125] L. P. Cook, W. Wong-Ng, C. K. Chiang, and L. H. Bennett, Stoichiometric Variations in the 2122 (Tl:Ca:Ba:Cu Oxide)
High $T_{\mathrm{c}}$ Phase, in Ceramic Transaction, Vol. 18, Superconductivity in Ceramic Superconductors II, K. M. Nair, U. Balachandran, Y-M. Chiang, and A. Bhalla, eds., Am. Ceram. Soc., Westerville, OH (1991) pp. 65-71.

[126] L. P. Cook, W. Wong-Ng, and M. Paranthaman, Melting and Vaporization of the 1223 Phase in the System (Tl-Pb-Ba-Sr-CaCu-O), J. Res. Natl. Inst. Stand. Technol. 101, 675 (1996).

[127] W. Wong-Ng, G. Piermarini, and M. Gallas, X-Ray Diffraction Study of $\mathrm{BaLu}_{2} \mathrm{CuO}_{5}$ and $\mathrm{BaNd}_{2} \mathrm{CuO}_{5}$ at High Pressures, Powder Diffr. 11 (4), 305 (1996).

[128] S. Block, G. Pieramini, R. Munro, and W. Wong-Ng, The Bulk Modulus and Young's Modulus of the Superconductor $\mathrm{Ba}_{2} \mathrm{Cu}_{3} \mathrm{YO}_{7}$, in Adv. Ceram. Mater., Vol. 2(3B), Ceramic Superconductors, W. J. Smothers, ed., American Ceramic Society, Westerville, OH (1987) p. 601.

[129] W. Wong-Ng, G. Piermarini, and M. Gallas, X-Ray Diffraction Study of $\mathrm{BaNd}_{2} \mathrm{CuO}_{5}$ Under High Pressure, Adv. X-Ray Anal. 38, 741 (1995).

[130] F. Beech, S. Miraglia, A. Santoro, and R. S. Roth, Neutron Study of the Crystal Structure and Vacancy Distribution in the Superconductor $\mathrm{Ba}_{2} \mathrm{YCu}_{3} \mathrm{O}_{9-\delta}$, Phys. Rev. B 35, 8778-8782 (1987).

[131] R. Munro, H. F. McMurdie, H. Ondik, and T. A. Vanderah, Phase Equilbria Diagrams, in A Century of Excellence in Measurements, Standards, and Technology, A Chronicle of Selected NBS/NIST Publications, 1901-2000, NIST Special Publication 958, D. R. Lide, ed. (2001) p. 184-187.

About the authors: Winnie Wong-Ng is a senior research chemist in the Ceramics Division of the NIST Materials Science and Engineering Laboratory. Her research interests includes crystallography, phase equilibria, and crystal chemistry of high-temperature oxides, in particular, high $T_{\mathrm{c}}$ superconductors. Terrell A. Vanderah is group leader of the Phase Equilibria Group in the Ceramics Division. Her main research interests are in the area of crystal chemistry, crystal growth, and phase equibria of microwave dielectrics. Robert S. Roth is a guest scientist in the Ceramics Division. His research interests include phase equilibria, crystal chemistry, and crystallography of high temperature dielectric materials. He is an editor for the ACerS/NIST phase diagram project. Howard F. McMurdie is a guest scientist in the Ceramics Division. He is an editor for the ACerS/NIST phase diagram project and also for the ICDD Powder Diffraction File (PDF). The National Institute of Standards and Technology is an agency of the Technology Administration, U.S. Department of Commerce. 